\title{
FLOOD CHARACTERISTICS OF MISSISSIPPI STREAMS
}

By Mark N. Landers and K. Van Wilson, Jr.

U.S. GEOLOGICAL SURVEY

Water-Resources Investigations Report 91-4037

Prepared in cooperation with the

MISSISSIPPI STATE HIGHWAY DEPARTMENT

Jackson, Mississippi

1991 


\section{U.S. DEPARTMENT OF THE INTERIOR \\ MANUEL LUJAN, JR., Secretary \\ U.S. GEOLOGICAL SURVEY \\ Dallas L. Peck, Director}

For additional information write to:

\section{District Chief}

U.S. Geological Survey Suite 710, Federal Building 100 W. Capitol Street

Jackson, Mississippi 39269
Copies of this report can be purchased from:

U.S. Geological Survey

Books and Open-File Reports

Building 810

Box 25425, Federal Center

Denver, Colorado 80225 


\section{CONTENTS}

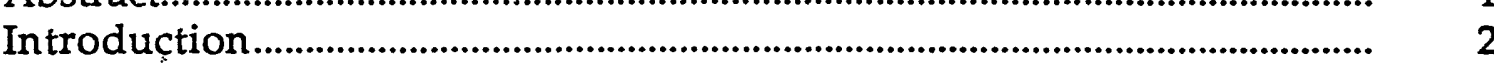

Purpose and scope .................................................................................... 2

General description of study area......................................................................

Acknowledgments ............................................................................................

Records of flooding............................................................................................... 5

Statistical characteristics of annual peak flow ....................................................... 6

Flood-frequency estimates from streamflow records......................................... 8

Weighted flood-frequency estimates............................................................... 9

Ungaged sites on gaged streams ..................................................................... 9

Accuracy of flood-frequency estimates for gaged stream sites ............... 11

Historical record evaluation ............................................................................. 12

Flood-frequency of the Pearl River main stem........................................... 13

Regional flood-frequency estimates for rural streams...................................... 18

Generalized-least squares regression............................................................ 19

Explanatory variables...................................................................................... 20

Regional boundaries.................................................................................... 20

Selection of the appropriate flood-frequency equation............................. $\quad 22$

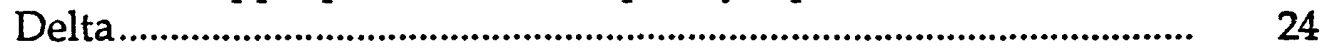

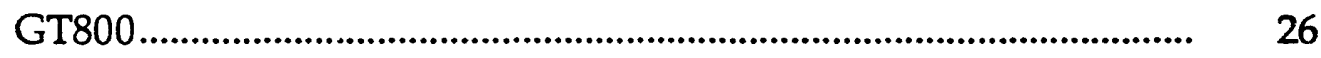

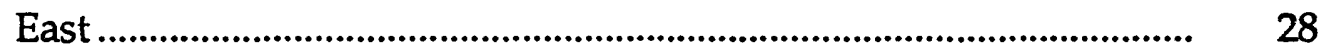

West............................................................................................... 30

Regional flood-frequency estimates for urbanized streams ............................ $\quad 30$

Limitations of regional flood-frequency estimates............................................ 37

Rural streams .................................................................................................. 37

Urbanized streams.............................................................................................. 39

Summary ...................................................................................................... 39

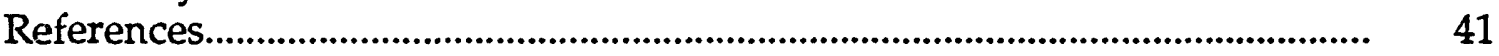

Appendix--Regional skew coefficients................................................................ 73 


\section{ILLUSTRATIONS}

Page

Figure 1. Map showing location of streamflow-gaging stations and flood-frequency regions.

Figures 2-14--Graphs showing:

2. Distribution of systematic peak-flow record lengths.

3. Relation of basin shape coefficient to drainage area for the Pearl River main stem.

4. Relation of flood-frequency discharge to drainage area for the Pearl River main stem

5. Relation of flood-frequency discharge for an average-shaped basin to drainage area for the Pearl River main stem

6. Relation of the 10-year discharge to basin characteristics

7. Characteristics of the 10-year flood residuals for the drainage basin subgroups and the whole-sample group of sites outside the Delta region

8. Characteristics of the 10-year flood residuals for the wholesample (statewide) group and for the Delta region

9. Distribution of drainage area for $\mathbf{2 8 2}$ gaging stations outside the Delta region

10. Characteristics of the 10-year flood residuals for drainage area subgroups and the whole-sample group of sites outside the Delta region

11. Characteristics of the 10-year flood residuals for drainage area subgroups and the whole-sample group of sites outside the Delta region having drainage areas less than or equal to 800 square miles.

12. Characteristics of the 10-year flood residuals for the wholesample group of sites outside the Delta region and for the principal subgroup regions. 


\section{ILLUSTRATIONS-Continued}

Page

13. Relation of observed 2-year, 10-year, and 100-year urban peak discharge to peak discharge estimated from equations 39,41 , and 44

14. Skew coefficient characteristics and boundaries of homogeneous skew regions in Mississippi

15. Map showing weighted-grid unbiased regional skew of logtransformed annual peak flow

16. Graph showing error of regional skew from weighted-grid and Interagency Advisory Committee on Water Data (IACWD) contour maps, where error of weighted-grid map is measured as the mean sum of squared prediction errors (MPRESS) and error of IACWD map is measured as mean square error (MSE)

\section{TABLES}

Table 1. Flood quantiles, standard error of estimate, and other information for gaging stations

2. Standard error of prediction for each flood-frequency regression equation

3. Additional basin characteristics for urban streams in Mississippi

4. Errors of prediction using the seven-parameter nationwide equations for urbanized streams in Mississippi

5. Characteristics of explanatory variables used in regression calculations for basins in the East and West regions with areas less than or equal to 800 square miles, basins in the Delta, and basins in the East or West regions with areas greater than 800 square miles (GT800)

6. Gaging stations used in skew coefficient analysis 


\section{CONVERSION FACTORS AND VERTICAL DATUM}

\begin{tabular}{|c|c|c|}
\hline$\underline{\text { Multiply }}$ & By & To obtain \\
\hline inch (in.) & 2.54 & centimeter \\
\hline foot $(f t)$ & 0.3048 & meter \\
\hline mile (mi) & 1.609 & kilometer \\
\hline foot per mile $(\mathrm{ft} / \mathrm{mi})$ & 0.018939 & meter per kilometer \\
\hline square mile $\left(\mathrm{mi}^{2}\right)$ & 2.590 & square kilometer \\
\hline cubic foot per second $\left(\mathrm{ft}^{3} / \mathrm{s}\right)$ & 0.02832 & cubic meter per second \\
\hline
\end{tabular}

Sea Level: In this report, "sea level" refers to the National Geodetic Vertical Datum of 1929 (NGVD of 1929)--a datum derived from a general adjustment of the first-order level nets of both the United States and Canada, formerly called Sea Level Datum of 1929. 


\title{
FLOOD CHARACTERISTICS OF MISSISSIPPI STREAMS
}

\author{
by Mark N. Landers and K. Van Wilson, Jr.
}

\begin{abstract}
Flood magnitudes for selected recurrence intervals from 2 to 500 years were determined for 330 gaged sites in the study area where annual peak-flow records have been collected. The principal study area is Mississippi; however, selected data collected in adjoining States on streams draining into or from Mississippi are also included. Flood frequency at a gaged stream site is defined by fitting the Pearson Type III probability distribution to the logtransformed annual peaks. The accuracy of the flood frequency determined for a gaged site is determined primarily by the number of years of annual peak-flow record (the sample size). Greater accuracy is achieved in the current analysis than in previous analyses because of the additional years of annual peak-flow record. Flood-frequency and basin characteristics at gaged sites were used to develop regression equations for estimating flood frequency where annual peak-flow records are not available.

Flood frequency for ungaged stream sites in Mississippi may be estimated using basin characteristics in regression equations. Regression equations were computed using the generalized-least-squares procedure rather than the ordinary-least-squares procedure used in previous regional hydrologic analyses. The generalized-least-squares procedure considers the variable error of the gaging station flood frequencies and corrects for the crosscorrelation of concurrent annual peaks. When the gaging stations in the sample for regression analysis have widely varying record lengths and concurrent peak flows, which are correlated between sites, the generalizedleast-squares procedure provides more accurate estimates of the regression coefficients and model error than does the ordinary-least-squares procedure. These flood-frequency equations provide managers with improved tools for estimating flood frequencies for purposes of management and design.
\end{abstract}




\section{INTRODUCTION}

The magnitude and frequency of floods are key factors in the design of bridges, highway embankments, culverts, levees, dams, and other structures near streams. Effective flood-plain management and the determination of flood insurance rates also require information on the magnitude and frequency of floods.

The Mississippi State Highway Department and the Federal Highway Administration recognize the need for adequate flood-frequency information for the safe, efficient design of drainage structures and roadways in Mississippi. Because of this need, the U.S. Geological Survey, in cooperation with the Mississippi State Highway Department, conducted a study to update previous flood-frequency reports using data collected through the 1988 water year. A water year, which is the 12-month period from October 1 to September 30, is designated by the calendar year in which it ends. Thus, the 12-month period ending September 30, 1988, is called the "1988 water year."

\section{Purpose and Scope}

The purpose of this report is to provide techniques for estimating the magnitude of floods with selected recurrence intervals from 2 to 500 years for streams in Mississippi. This report supersedes an earlier one by Colson and Hudson (1976) because of additional available data and new analytical techniques.

The principal study area is Mississippi; however, selected data collected in adjoining States on streams draining into or from Mississippi are also included (fig. 1). Estimates of flood magnitude are presented for 330 streamflow gaging stations in the study area. Regional estimating equations were developed to provide flood-frequency information at ungaged locations. The regional flood-frequency equations were developed using a new procedure, generalized-least-squares regression (Stedinger and Tasker, 1985, 1986), which better addresses statistical problems of hydrologic variables in regional hydrologic analyses than does ordinary-least-squares regression. Floodfrequency equations were developed for streams in four subgroups; three defined by geographic region and one by drainage-area magnitude. Additional equations for urban areas are presented from "Flood Characteristics of Urban Watersheds in the United States" (Sauer and others, 1983). 


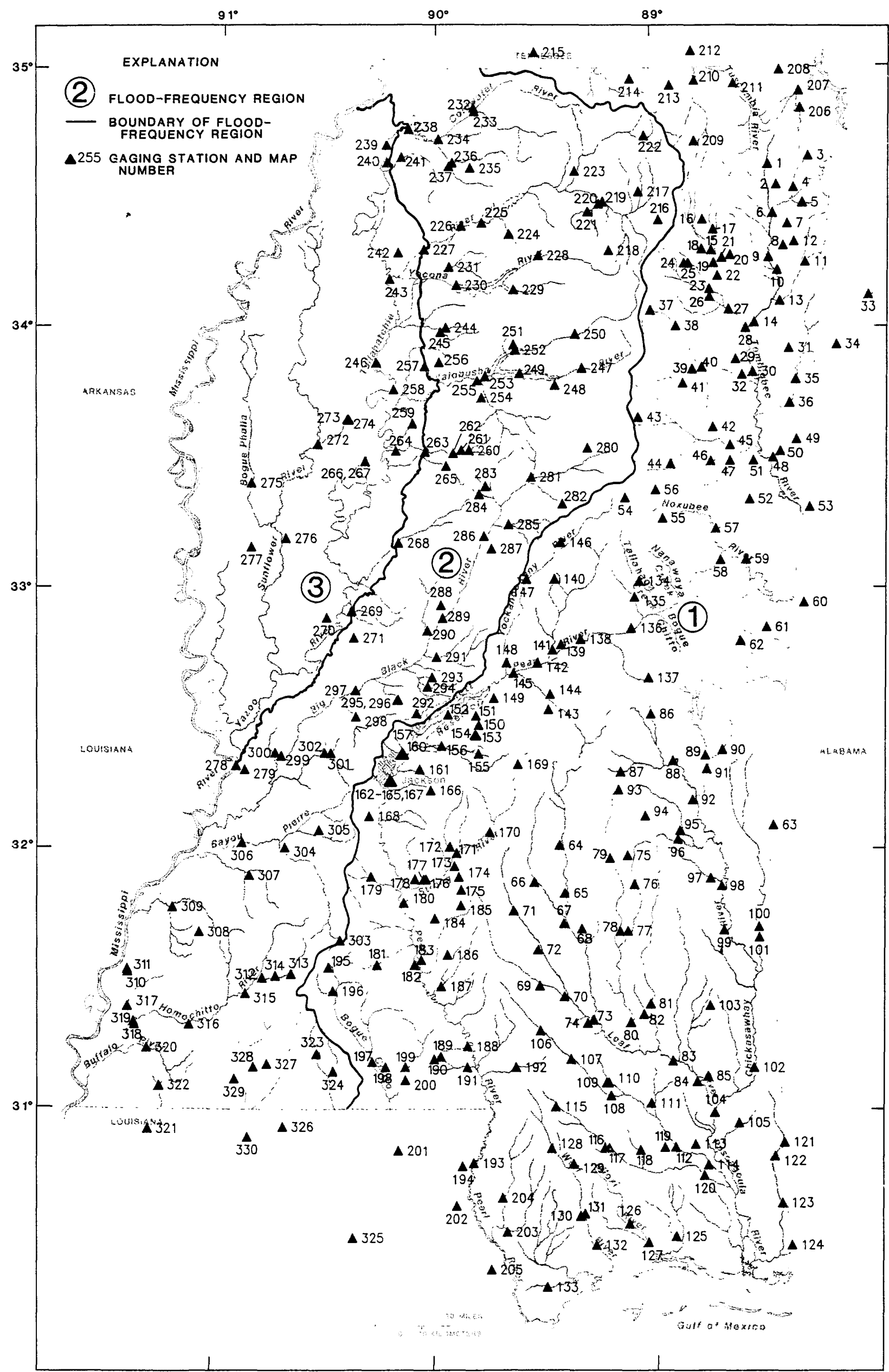

Figure 1.--Location of streamflow-gaging stations and flood-frequency regions. 


\section{General Description of Study Area}

Mississippi is in the East Gulf Coastal Plain and includes parts of several physiographic districts, but the State generally may be divided into the coastal plain uplands and the lower Mississippi River Alluvial Plain, known locally as the "Delta." The transition between the coastal plain uplands and the Delta is an abrupt, dissected escarpment characterized by steep slopes and pronounced ridges rising 150 to $250 \mathrm{ft}$ above the alluvial plain.

The Delta, in the northwestern part of the State, is a flat, lens-shaped basin having a maximum width of about $65 \mathrm{mi}$. The topography is a series of abandoned meander belts, oxbow lakes, and swamps. Regional drainage characteristics are broad, widely meandering stream courses trending to the southwest with low channel slopes and large amounts of depression and channel storage. Extensive levees protect all but the southern part of the alluvial plain from floodwaters of the Mississippi River.

The coastal plain uplands is composed of hilly uplands and gently undulating prairies. The maximum elevation in the State is located in the coastal plain uplands in the northeast corner of the State, where elevations reach about $806 \mathrm{ft}$ above sea level.

The six major drainage basins in Mississippi are the Yazoo, Big Black, Homochitto, Tombigbee, Pascagoula, and Pearl. The Yazoo, Big Black, and Homochitto basins drain southwestward into the Mississippi River. The Tombigbee basin drains southward into the Mobile River. The Pascagoula and Pearl basins drain southward into the Gulf of Mexico.

The climate of Mississippi is controlled primarily by the proximity of the Gulf of Mexico and the prevailing southwesterly winds. These conditions contribute to a generally warm and humid climate, making Mississippi one of the two wettest States in the contiguous United States. The average annual precipitation ranges from 54 inches in the northern part of the State to about 60 inches in the southern part (Wax, 1982).

\section{Acknowledgments}

The U.S. Army Corps of Engineers and many State and local agencies are acknowledged for their cooperation in the collection of much of the data used in the study. 


\section{RECORDS OF FLOODING}

Records of annual peak flow collected at streamflow-gaging stations provide the empirical basis for estimates of flood characteristics. In this study, the records were analyzed for 330 locations (fig. 1, table 1) on streams in and near Mississippi to provide a total of 8,470 years of systematic annual peakflow records.

Systematic records represent a random sample of annual peak flows at a site, generally collected over a continuous period. The distribution of systematic peak-flow-record lengths used in the regional analyses is shown in figure 2. A minimum of 10 years of record was considered necessary for estimating flood characteristics for a gaged site.

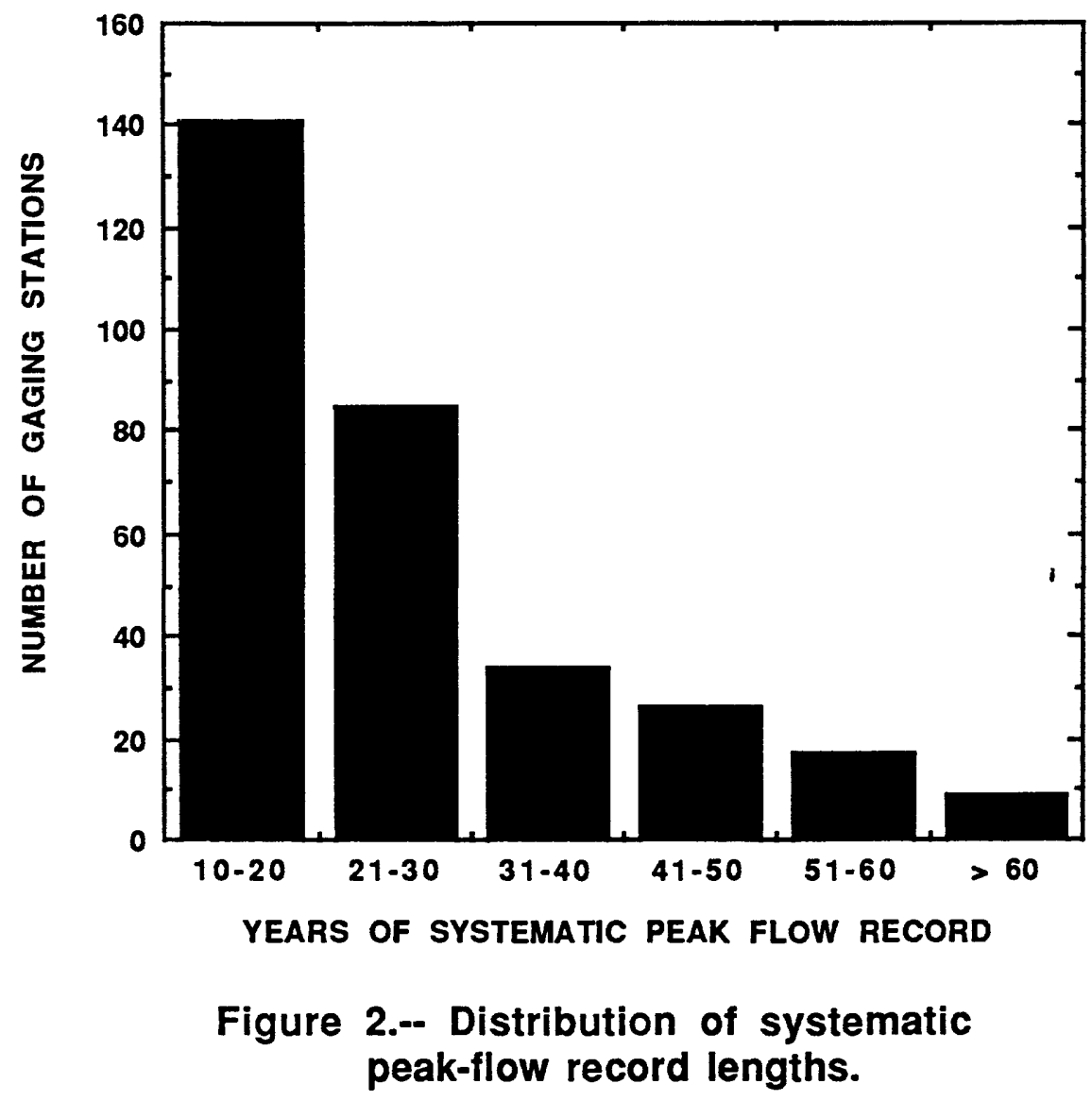


Floods of unusually large magnitude often occur at a site when systematic records are not being obtained from a streamflow gage. In this study, evidence of the occurrence of unusually large floods was obtained from newspaper files, old records of stage, local historical records, diaries, and from individuals who remembered the flood or were informed by their ancestors. This flood information, referred to as historical record in this report, was used when available to extend the record of the largest floods at a site to a historical period much longer than that of the systematic record. Historical record is available for about 40 percent of the Mississippi sites having 10 or more years of systematic record.

Synthetic data (flood peaks generated from climatic records in a rainfallrunoff model) were used in the report by Colson and Hudson (1976) to extend the length of record at 89 gage sites, ranging in drainage area from 0.04 to $4.35 \mathrm{mi}^{2}$. Additional data have been collected since 1976, and 84 of these sites now have 10 or more years of systematic record. The synthetic and recorded flood-frequency discharges for these gages were compared using a paired Student's t-test, as described by Thomas (1987). The Student's t-tests, at the 5percent level of significance for the 2-year to 100-year discharges, indicate that the synthetic data are statistically different from the systematic data for all except the 2-year and 5-year discharges. At the 1-percent level of significance, the difference was significant only at the 25-year and 100-year discharge. The bias of the synthetic data at the 5-percent level of significance was also reported by Colson (1986) and Thomas (1987). Therefore, the flood-frequency discharges based only on the systematic record were used in this study.

\section{STATISTICAL CHARACTERISTICS OF ANNUAL PEAK FLLOW}

Statistical methods of analysis are well suited to the random nature of annual flooding. Statistical methods may be used to estimate flood frequency from a sample of recorded annual peak flows at a stream site using the assumption that the recorded sample represents the population of all the recorded and unrecorded annual peak flows. The Interagency Advisory Committee on Water Data (IACWD, 1982) recommends that the Pearson Type III distribution be used as the probability model for log-transformed annual peak-flow data. The Pearson Type III distribution requires estimates of the population mean, variance, and skew at a site. These population parameters 
are estimated by computing the corresponding sample parameters, based on the systematic record, as follows:

$$
\begin{gathered}
\bar{X}=\frac{1}{N} \sum_{i=1}^{N} X_{i} \\
S^{2}=\frac{1}{N-1} \sum_{i=1}^{N}\left(X_{i}-\bar{X}\right)^{2} \\
G_{S}=\frac{N}{(N-1)(N-2) S^{3}} \sum_{i=1}^{N}\left(X_{i}-\bar{X}\right)^{3}
\end{gathered}
$$

where

$$
\begin{aligned}
& \overline{\mathbf{X}} \text { is the sample mean; } \\
& \mathbf{S} \text { is the sample standard deviation; } \\
& \mathbf{S}^{2} \text { is the sample variance; } \\
& \mathrm{G}_{\mathbf{S}} \text { is the sample skew; } \\
& \mathbf{X}_{\mathbf{i}} \text { is the log-transformed annual peak flow for year } \mathrm{i}_{\text {; }} \\
& \mathbf{N} \text { and } \\
& \text { is the sample size, that is, the number of years of } \\
& \text { peak-flow record for the stream site. }
\end{aligned}
$$

Previous studies of the sampling distribution of sample skew $\left(G_{S}\right)$ have shown that $G_{S}$ is a biased estimator of the population skew and is subject to large sampling variances as compared with $\bar{X}$ and $S^{2}$. Empirical bias correction factors were computed by Wallis and others (1974) based on Monte Carlo experiments. A bias correction equation based on record length and described by Tasker and Stedinger (1986) was used by Landers (1989), and is defined as:

$$
C_{b}=(1+6 / N)
$$


where $C_{b}$ is the bias correction coefficient and $\mathbf{N}$ is as defined previously. Sample skew coefficients were multiplied by this bias correction coefficient and used to develop unbiased regional skew coefficients.

Tasker and Stedinger (1986) showed only minor differences between bias correction coefficients from this equation and from the empirical results of Wallis and others (1974), when $\mathbf{N}$ is greater than 20 and the absolute value of $\mathrm{G}_{\mathbf{S}}$ is less than 1.0.

Population skew estimates are improved when computed from the weighted average of the sample and unbiased regional skew estimates for a site, as recommended by the IACWD (1982). Sample skew $\left(G_{\mathbf{S}}\right)$ is weighted inversely to its mean square error $\left(\mathrm{MSE}_{\mathbf{S}}\right)$, and regional skew $\left(\mathrm{G}_{\mathbf{r}}\right)$ is weighted inversely to an estimate of its sampling variance $\left(\mathrm{MSE}_{\mathbf{r}}\right)$. The IACWD (1982) uses mean square error $\left(\mathrm{MSE}_{\mathbf{r}}\right)$ as an estimate of the sampling variance of regional skew. Population skew then is estimated by:

$$
\hat{G}=\frac{\left(M S E_{r} * G_{S}\right)+\left(M S E_{S} * G_{r}\right)}{M S E_{r}+M S E_{S}}
$$

where

$$
\begin{aligned}
& \hat{G} \text { is an estimate of the population skew coefficient, and } G_{\mathbf{r}} \\
& \text { is assumed to be unbiased so that } M S E_{\mathbf{r}} \text { is equal to the } \\
& \text { sampling variance of } G_{\mathbf{r}} \text {. }
\end{aligned}
$$

Further improvements in estimated population skew are obtained by using weighted methods to estimate regional skew. Regional skew for Mississippi streams was studied in detail, and was described by Landers (1989) in a report that included a comparison of estimation techniques. The selected regional estimator is an unbiased, weighted-grid skew map. Regional skew coefficients for Mississippi are discussed in the Appendix.

\section{FLOOD-FREQUENCY ESTIMATES FROM STREAMFLOW RECORDS}

Flood-frequency estimates from records of annual peak flow at 330 gaging stations were computed by fitting the three-parameter Pearson Type III distribution to the sample of log-transformed annual peak flows, as recommended by the IACWD (1982). The regional unbiased map skew 
developed by Landers (1989) was used with the biased station skew to provide the Water Resources Council (WRC) weighted estimation of population skew. (The existing IACWD guidelines do not recommend the unbiasing of station skew.) Computations were made using U.S. Geological Survey computer program J407, "Annual Flood Frequency Analysis Using WRC Guidelines" (Lepkin and others, 1981).

Stream basins were reviewed to determine if the basins were affected by regulation or channelization, which may violate the stationary time series assumption and make the station unrepresentative of regional floodfrequency characteristics. Data from sites in basins that were regulated or channelized during the period of record were analyzed to determine the effect of regulation or channelization (noted in table 1) on annual peak-flow records. In several basins, gages were in place prior to significant regulation or channelization. For each of these gaging stations, the period of record prior to significant regulation or channelization was used to expand the natural, regional data base. However, flood-frequency information for these gages given in table 1 represents existing conditions. Station flood-frequency values are not weighted with regional values for regulated or channelized streams.

\section{Weighted Flood-Frequency Estimates}

If two independent estimates of flood frequency are weighted in inverse proportion to their error (variance), the error of the weighted average is less than that of either estimate (IACWD, 1982). The regional flood-frequency estimates developed in this investigation are assumed to be independent of the station flood-frequency estimates. The two estimates were weighted inversely proportional to their respective time-sampling and prediction errors to obtain a best estimate of flood-frequency at each gage in accordance with Appendix 8 of Bulletin 17B (IACWD, 1982). The estimates shown in table 1 for selected recurrence intervals from 2 to 500 years are weighted estimates unless otherwise noted.

\section{Ungaged Sites on Gaged Streams}

Flood-frequency estimates from a gaged stream site may be extrapolated to an ungaged site on the same stream using drainage area ratios raised to the 
0.6 power. This procedure is suggested if the drainage area at an ungaged site is within 50 percent of the drainage area at the gaged site on the same stream. This extrapolated estimate and the regional regression estimate for the ungaged site are weighted in the following equation:

$$
\mathrm{Q}_{\mathrm{T}(\mathrm{w})}=4\left(\frac{\Delta \mathrm{A}}{\mathrm{A}_{\mathrm{g}}}\right)^{2} \mathrm{Q}_{\mathrm{r}}+\left[1-4\left(\frac{\Delta \mathrm{A}}{\mathrm{A}_{\mathrm{g}}}\right)^{2}\right]\left(\frac{\mathrm{A}_{\mathrm{u}}}{\mathrm{A}_{\mathrm{g}}}\right)^{0.6} \mathrm{Q}_{\mathrm{g}}
$$

where

$\mathrm{Q}_{\mathrm{T}(\mathrm{w})}$ is the weighted discharge, in cubic feet per second, at the ungaged site for a recurrence interval of $T$ years;

Q is the weighted gage discharge, in cubic feet per second, for the selected recurrence interval, from table 1;

$\mathbf{Q}_{\mathbf{r}}$ is the regional regression discharge, in cubic feet per second, at the ungaged site for the selected recurrence interval;

$\mathbf{A}_{\mathbf{u}}$ is the drainage area, in square miles, at the ungaged site;

$\mathbf{A}_{\mathbf{g}}$ is the drainage area, in square miles, at the gaged site; and

$\Delta \mathbf{A} \quad$ is the difference between the drainage areas at the gaged and ungaged sites.

Where the drainage area at an ungaged site differs by more than 50 percent from that at the gaged site, the regional estimate should be used. If an ungaged site is between two gaged sites on the same stream, the suggested "50 percent rule" should be applied to determine which gaged site, if either, should be used to make an adjustment to the regional estimate at the 
ungaged site. If the drainage area at the ungaged site is within 50 percent of that at both gaged sites, the flood-frequency estimate for the ungaged site can be interpolated logarithmically, on the basis of drainage area, between the weighted gage discharges $\left(\mathbf{Q}_{\mathrm{g}}\right)$ from each gaged site.

\section{Accuracy of Flood-Frequency Estimates for Gaged Stream Sites}

"Streamflow characteristics can only be estimated; their true value can never be determined because there is a time-sampling error in every record of streamflow and a model error in every analytical method" (Hardison, 1969). It is important to evaluate the error associated with a given flood estimate because of the large range of accuracy that may be obtained in flood estimates using different methods. A measure of the accuracy or error of a flood estimate is necessary to evaluate the confidence or factor of safety with which it should be used, to compare and select methods of estimation, and to serve as a basis for risk analysis. Accuracy may be indicated by the variance or standard error of estimate.

Flood estimates from peak-flow records may contain errors due to: (1) any systematic measurement or computational errors, (2) use of an unrepresentative population probability distribution, or (3) errors in estimation of the population parameters defining the frequency distribution (time-sampling errors). The first source of error is addressed by quality assurance procedures in the data collection, computation, and review process. These errors generally are small and, in fact, non-systematic. The second source of error exists because the population of floods defies consistent, precise representation by any frequency distribution. The third source of errors lies in the estimation of population frequency distribution parameters for the sample data. This time-sampling error is assumed to be large, compared to the other two sources of error discussed. Time-sampling error is the only error quantified in the standard error of a flood-magnitude estimate from station peak-flow records for a recurrence interval $(T)$. The standard error of the T-year flood estimate is the sum of errors in the estimation of the mean, the standard deviation, and the skew of the Pearson Type III distribution from the logarithms of annual peak flow for a given site. The time-sampling error is a function of the slope of the frequency curve (sample standard deviation), the estimated skewness, the recurrence interval $(T)$ being 
estimated, and the length of record as a measure of how representative the sample may be of the population of annual peaks. Methods of computing the standard (time-sampling) error have been presented by different authors [Bobee (1973), (Hardison (1971), and Kite (1988)]. This report uses the method described by Kite (1988) to compute the time-sampling errors for each station flood-frequency estimate. These time-sampling errors are combined with the error of prediction of the regional estimator to compute the standard error of the weighted estimate. The standard error, in percent, is shown in table 1 for the corresponding weighted or station flood-flow estimates.

The standard error of estimate is an indicator of the accuracy of a floodfrequency estimate. It is the square root of the variance of estimate about the unknown, true value being estimated. When errors are normally distributed, about two-thirds of the estimates are expected to lie within one standard error greater than or less than the true value. Ninety-five percent of the estimates are expected to be within two standard errors greater than or less than the true value. In this report, standard error is reported as a percentage of the true value being estimated. Thus, if a 10-year flood of magnitude $1,000 \mathrm{ft}^{3} / \mathrm{s}$ has a standard error of 30 percent, the true value would be expected to be between about 700 and $1,300 \mathrm{ft}^{3} / \mathrm{s}$ about two-thirds of the time.

\section{Historical Record Evaluation}

Evaluation of historical record in flood-frequency analyses is complex, and the most appropriate method is not certain at this time. In this investigation, historical records are included in the computation of Pearson Type III flood-frequency estimates using the adjusted-moment method recommended by IACWD (1982) and included in the J407 computer program (Lepkin and others, 1981). The effective record length obtained from the contribution of information from the historical record is required for computing the standard error of station flood-frequency estimates and for weighting station estimates with regional flood-frequency estimates. For a given recurrence interval, the effective record length is the number of years of systematic data that would produce the same standard error as a given combination of historical and systematic data (Stedinger and Cohn, 1986). Effective record length for stations having historical records was based on results of Monte Carlo simulations by Stedinger and Cohn (1986), which were 
provided in a sub-routine of the generalized-least-squares regression model by Tasker and Stedinger (1989). The effective record length computed in the generalized-least-squares regression model was used in the computation of standard error.

\section{Flood-Frequency of the Pearl River Main Stem}

The Pearl River is formed by the confluence of Tallahaga Creek, Nanawaya Creek, and Bogue Chitto about 85 miles northeast of Jackson, Miss., and flows southward through Jackson and into the Gulf of Mexico (fig. 1). Upstream of Jackson, the drainage basin is average- or fan-shaped; whereas, the basin is typically elongated downstream, except where major tributaries flow into the Pearl River causing the basin shape to fan out.

The Ross Barnett Reservoir, located about 10 miles northeast of Jackson (fig. 1), is designed primarily for water supply and recreation; however, it has been used successfully to provide some flood-peak reduction. The reservoir normally is operated so that the pool is maintained at a near-constant level, and the inflow is passed through without significant attenuation. Since completion of the reservoir, the largest and third largest floods of record on the Pearl River at Jackson occurred in April 1979 and in May 1983. These flood-peak discharges at the Jackson gage, located at U.S. Highway 80 in south Jackson, were compared with discharges at State Highway 43 (Meeks Bridge) near Canton (about 12 miles upstream from the dam). The comparison indicated the May 1983 flood peak was reduced about 20 percent by the regulation of the Ross Barnett reservoir discharge, and the April 1979 flood peak may have been reduced a lesser amount. Some natural flood-peak attenuation between the gages at Meeks Bridge and at Jackson was expected due to variation in basin shape, which was indicated by adjusting the peak discharges at Meeks Bridge and at the Jackson gage for basin shape.

A basin shape coefficient developed by Wilson and Trotter (1961) was used in this report to demonstrate the effect of basin shape on flood flows along the Pearl River main stem (fig. 3). This basin shape coefficient is inversely related to the ratio of the distance that flood waters must travel divided by average width of the basin. Wilson and Trotter (1961) reported shape coefficients ranging from 0.55 to 1.48 for corresponding length-to-width ratios ranging from 13.0 to 1.50 for Mississippi streams (excluding the Delta). 


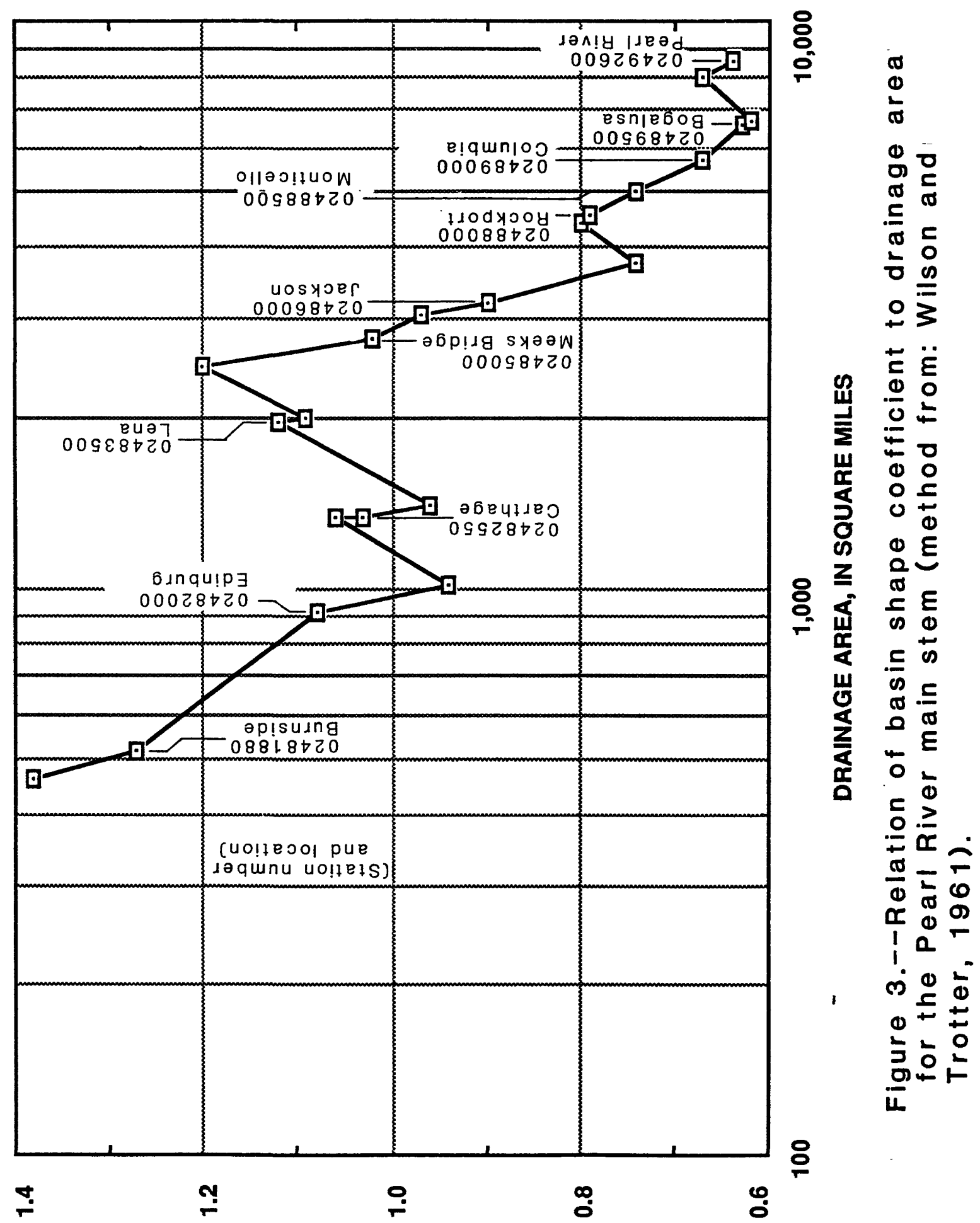

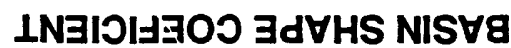


The ratio is computed using $r=L^{2} / A$, where $r$ is the ratio, $L$ is the valley length, and $A$ is the drainage area. For a drainage area of $1.0 \mathrm{mi}^{2}, L$ for shape coefficients of 0.55 and 1.48 are 3.61 and $1.22 \mathrm{mi}$, respectively. Therefore, a larger basin shape coefficient would suggest a more fan-shaped basin; whereas, the smaller coefficient would suggest a more elongated basin with the coefficient of 1.0 for an average-shaped basin. The elongated basin would tend to provide more channel storage and dissipation of flood flows primarily because of the longer flow length.

The basin shape coefficient was determined along the Pearl River main stem from Burnside (near the confluence of Tallahaga Creek, Nanawaya Creek, and Bogue Chitto) to Pearl River, La. In this river reach, the coefficient was determined at each gaging site and at the mouth of each major tributary (fig. 3).

Flood-frequency discharges for 11 sites on the Pearl River are shown in table 1 and are plotted with drainage area in figure 4. The discharges for seven of these sites were agreed upon in 1980 by the U.S. Geological Survey and the U.S. Army Corps of Engineers, Mobile District, following the April 1979 flood. These sites were re-analyzed to include record through the 1988 water year, but analyses indicated that no revisions were warranted. For the other four sites (Burnside, Lena, Meeks Bridge, and Rockport), the records were extended using correlations with the nearest long-term station in accordance with Appendix 7 of Bulletin 17B (IACWD, 1982). The floodfrequency discharges for each site were divided by the appropriate basin-shape coefficient (fig. 3) to determine the discharges for an average-shaped basin (fig. 5).

If an estimate of a discharge for a specific frequency is needed for an ungaged site on the Pearl River, it is necessary to: (1) determine the drainage area, (2) obtain the discharge for an average-shaped basin from figure 5, and (3) multiply by the appropriate basin shape coefficient from figure 3. 


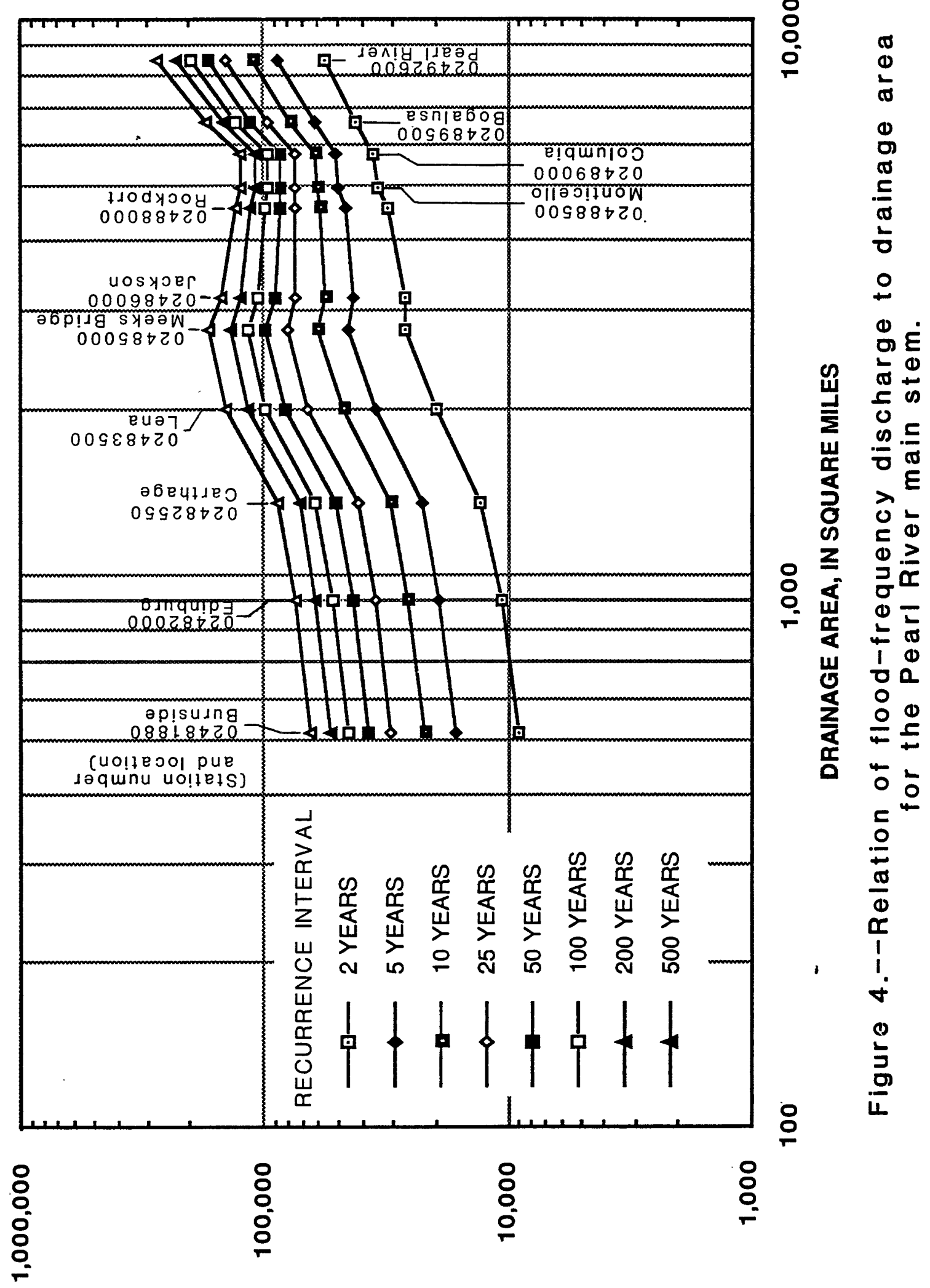

aNOOتS y

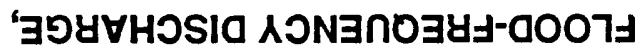




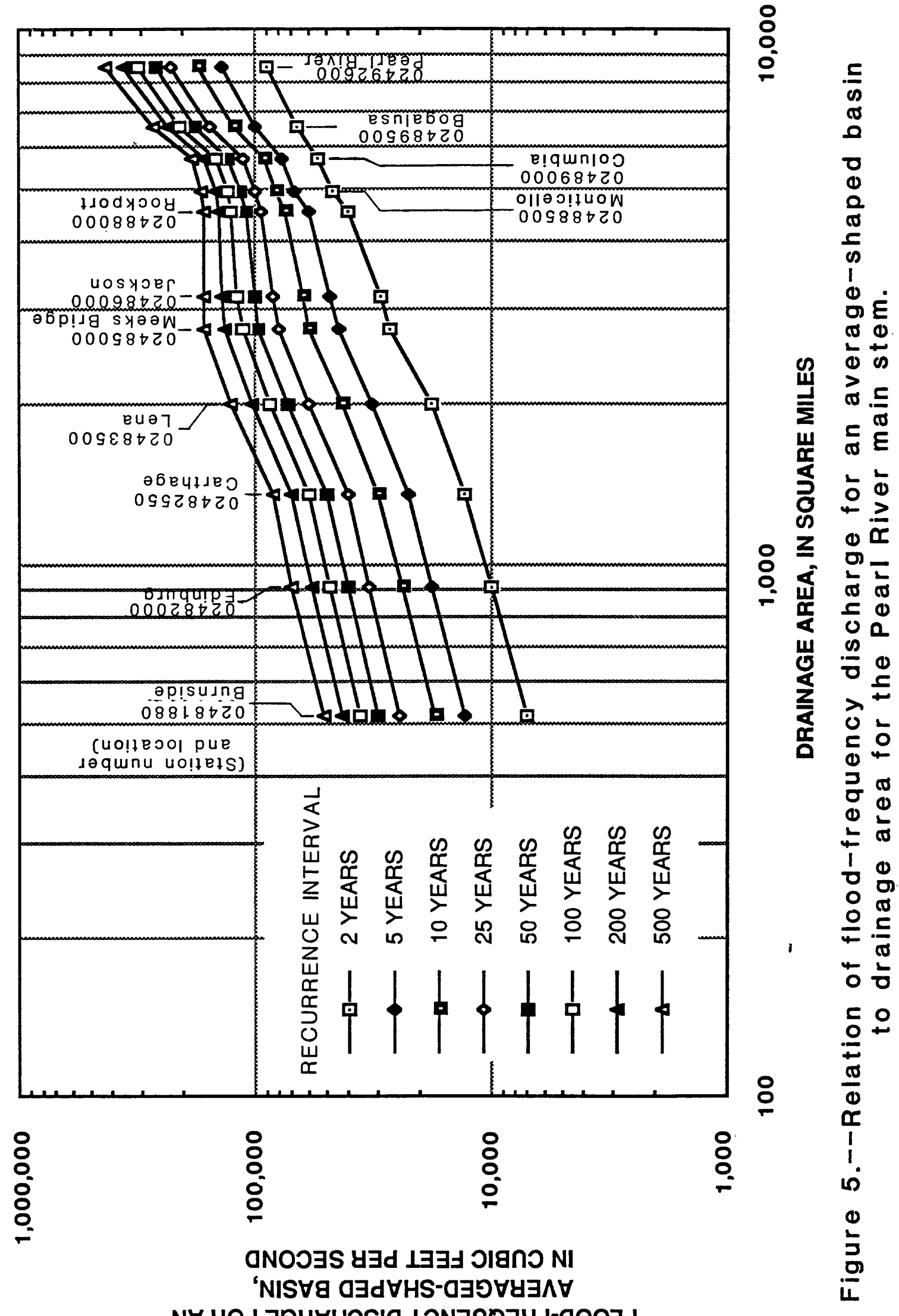

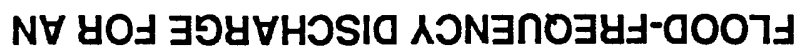




\section{REGIONAL FLOOD-FREQUENCY ESTIMATES FOR RURAL STREAMS}

Streamflow gaging records are available at only a small percentage of the stream sites where flood-frequency estimates are needed. Regionalization procedures are necessary to transfer flood-characteristic information from gaged to ungaged sites. Regional flood-frequency estimates also improve accuracy at a gaged site by weighting with station estimates, assuming that the station estimate is independent of the regional estimate. Regionalization procedures generally define relations between flood-frequency characteristics and explanatory drainage basin variables for gaged streams that are representative of similar streams in a specific class or region. Regionalization procedures have been the subject of much research through the years, and methods used by the U.S. Geological Survey have evolved as a result.

Graphical index-flood regionalization procedures were used by Wilson and Trotter (1961) for estimating flood magnitudes with recurrence intervals from 1.2 to 50 years for separate regions of the State. This detailed analysis included an adjustment factor for basin shape. Index-flood procedures were also presented by Patterson (1964) for streams in the lower Mississippi River basin and by Barnes and Golden (1966) for streams in the South Atlantic Slope and eastern Gulf of Mexico basins, Ogeechee River to the Pearl River, including parts of Mississippi. Continuing research by the U.S. Geological Survey led to the use of ordinary-least-squares (OLS) regression procedures to estimate $\mathrm{T}$-year floods directly from drainage basin or climatic explanatory variables (Thomas and Benson, 1970). Regional T-year flood estimators for recurrence intervals from 2 to 100 years were determined using OLS procedures and were reported by Colson and Hudson (1976) for streams statewide, and by Landers (1985) for streams in the Lower Mississippi River Alluvial Plain. Recent developments in the regionalization of flood characteristics have centered on accounting for the deficiencies in the assumptions of OLS regression when applied to hydrologic variables.

Regional estimators of annual peak flood magnitude were computed in this study for recurrence intervals from 2 to 500 years. The maximum recurrence interval was 50 years in the report by Wilson and Trotter (1961) and 100 years in the report by Colson and Hudson (1976). Maximum recurrence-interval is increased in this report because of changes in design standards requiring estimates of the 200-year and 500-year recurrence 
intervals and not because of an improvement in the confidence given to the accuracy or methods.

\section{Generalized-Least-Squares Regression}

Two significant assumptions of OLS that usually are violated when estimating $\mathrm{T}$-year floods are: 1 ) the errors are statistically uniform (homoscedastic), and 2) the observations are statistically independent in the sample. The error of $\mathrm{T}$-year flood estimates varies from stream to stream with the length of record used to make the estimates. Also, T-year flood estimates may be correlated between streams experiencing similar climatic conditions and having similar drainage basin characteristics.

A procedure for estimating regional flood frequencies recently has been proposed by Stedinger and Tasker (1985 and 1986) that uses a weighting matrix to account for the time-sampling error and the cross-correlation of flood characteristics between sites. This procedure is called generalized-leastsquares regression (GLS).

Cross-correlation between observations is estimated as a function of distance between gaged sites. The correlation-distance function is estimated from gages having long, concurrent record periods and in this study, is estimated from station pairs having concurrent record periods in excess of 30 or 50 years, depending on the region within the State. GLS regression also requires matrices of the mean, standard deviation, and skew associated with the matrix of log-transformed station T-year flood estimates. The standard deviation and skew matrices should be independent of the residual errors of the regional estimators in order that the model error can be quantified from the total residual error. In this study, regional estimates of the mean and standard deviation were computed using OLS regression of station mean and standard deviation against log-transformed drainage area and slope. The independent matrix of skews was estimated by using the matrix of estimates of population skew coefficients at each station.

Because GLS procedures compute and account for the time-sampling error and cross correlation of the observed $T$-year values, the total error of prediction of the regression equation may be divided into time-sampling errors arising from data limitations and model error arising from model limitations. Stedinger and Tasker (1985) used Monte Carlo simulations to 
prove that, "In situations where the available streamflow records at gaged sites are of different and widely varying length and concurrent flows at different sites are cross-correlated, the GLS procedure provided more accurate parameter estimates, better estimates of the accuracy with which the regression model's parameters were being estimated, and almost unbiased estimates of the variance of the underlying regression model's residual errors," as compared with OLS or weighted-least-squares procedures.

\section{Explanatory Variables}

Regional flood-frequency estimators provide a means of extending the information gained at gaged locations to ungaged locations. Station T-year flood estimates were regressed on a range of potential explanatory variables including: drainage area, channel slope, channel length, mean basin elevation, basin shape factors, mean annual precipitation, and precipitation intensity. This testing was also performed on subgroups of the whole-sample group of sites, according to drainage area, region, and recurrence interval. Significant explanatory variables are drainage area, channel slope, and channel length. Logarithms of discharge have an approximately linear relation with logarithms of the selected basin characteristics, as shown in figure 6. The inverse relation of channel length, as a basin shape factor to discharge, is also illustrated in figure 6.

\section{$\underline{\text { Regional Boundaries }}$}

An underlying assumption of regional flood-frequency relations is that the relation between $T$-year flood discharges and basin characteristics is similar for each stream and may be generalized for all streams represented in the data sample. This assumption was tested by comparing the regression residuals (observed value minus predicted value) between the whole-sample groups and selected subgroups. Tested subgroups were selected on the basis of major drainage basin boundaries, known regional variations in flood characteristics, and drainage area. Hypothesis tests were used to compute the probable equivalence between the whole-sample group and subgroups of the mean and median OLS regression residuals of the 10-year flood estimate. 

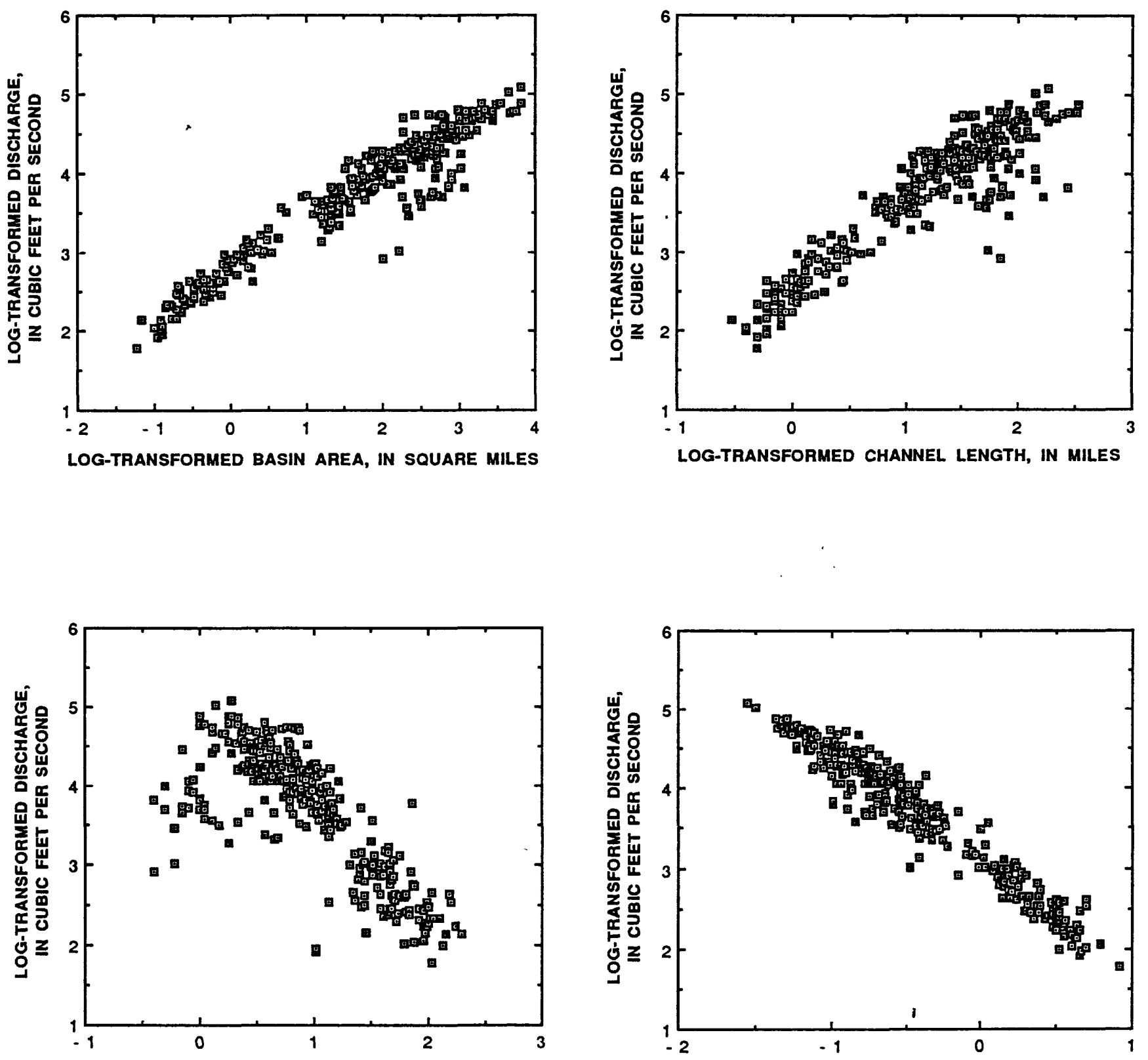

Log-tRANSFORMEd ChaNNEL SLOPE, IN FEet PER MILE

LOG-TRANSFORMED CHANNEL. LENGTH PER SQUARE MILE OF BASIN AREA, IN MILES

Figure 6.--Relation of the 10-year discharge to basin characteristics. 
Figure 7 shows the characteristics of the OLS residuals for sites within the major drainage basin subgroups for an equation computed from the wholesample group of sites outside the Delta region. These comparisons were also made using unweighted GLS residuals with similar results.
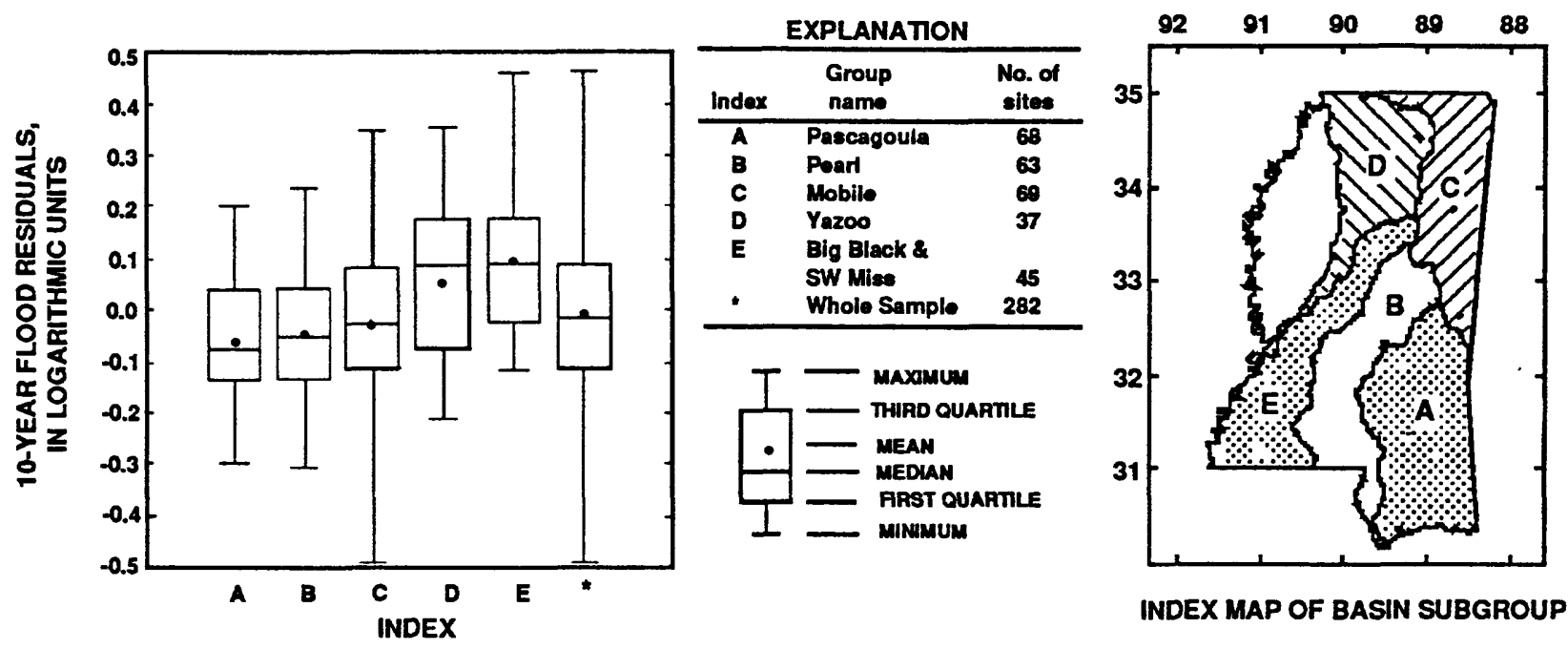

Figure 7. . - Characteristics of the 10-year flood residuals for the drainage basin subgroups and the whole-sample group of sites outside the Delta region.

Flood characteristics were determined to be non-homogeneous among four subgroups. Three of these subgroups are defined by geographic boundaries and one by drainage area magnitude. Regional flood-frequency equations were computed for each subgroup. Urbanized drainage basins were also analyzed separately.

\section{Selection of the Appropriate Flood-Frequency Equation}

Techniques for estimating the magnitude of floods with recurrence intervals from 2 to 500 years in Mississippi are provided in this report. If flood-frequency information is needed at a gaged site, it should be obtained from table 1. If the gage is not listed in table 1 , the user must decide whether the appropriate estimate is obtained by weighting the station and regional estimates or from the unweighted station estimate (as when a stream is regulated or otherwise regionally unrepresentative.) 
If flood-frequency information is needed at an ungaged site or if a regional estimate is needed to weight with a station estimate, then the appropriate regional flood-frequency equation must be selected. A user would select: (1) the Delta equations, if the stream is in the Delta; (2) the GT800 equations, if the stream is outside the Delta with drainage area greater than 800 square miles (GT800); or (3) the East or West equations, based on stream-site location (fig. 1). In figure 1, regions 1, 2, and 3 are the East, West, and Delta regions, respectively. The Delta and West boundary is crossed by stream basins sloping westward down the abrupt, dissected escarpment. For ungaged sites located in the Delta part of these basins, it is suggested that two discharges be estimated for each frequency by assuming all of the basin lies in each region and then averaging the discharges by areal weight. Drainage basins affected by urbanization should be estimated using the equations presented from the report by Sauer and others (1983), with the appropriate rural estimating equation.

The accuracy for each flood-frequency equation may be measured by using the standard error of prediction. The standard error of prediction for each equation is shown in table 2 .

Table 2.--Standard error of prediction for each flood-frequency regression equation [GT800, basins in the eastern or western regions with areas greater than 800 square miles]

\begin{tabular}{ccccc}
\hline $\begin{array}{c}\text { Recurrence } \\
\text { interval, } \\
\text { in years }\end{array}$ & \multicolumn{5}{c}{$\begin{array}{c}\text { Standard error of prediction for each } \\
\text { region in percent }\end{array}$} \\
\hline & East & West & Delta & GT 800 \\
2 & 34 & 35 & 34 & 22 \\
5 & 27 & 31 & 34 & 19 \\
10 & 26 & 30 & 36 & 17 \\
25 & 27 & 31 & 38 & 16 \\
50 & 29 & 32 & 38 & 15 \\
100 & 31 & 34 & 40 & 15 \\
200 & 34 & 36 & 42 & 16 \\
500 & 38 & 39 & 45 & 17 \\
& & & & \\
\hline
\end{tabular}




\section{Delta}

The most significant flood-characteristic boundary in Mississippi is between the Deita and the remainder of the State. Wilson and Trotter (1961) and Landers (1985) presented this region of the State as a separate hydrologic area with a unique flood-frequency relation. Landers (1985) presented regional flood-frequency equations for recurrence intervals from 2 to 100 years, based on data from 30 gaging stations in this region in Mississippi, Louisiana, and Arkansas. Of these 30 sites, only 6 are located in Mississippi (table 1). Comparisons of the 10-year flood regression residuais of the subgroup of 30 Delta streams to the whole-sample (statewide) group of 312 streams confirm the uniqueness of the Delta region. The statistical characteristics of the residuals are shown in figure 8.
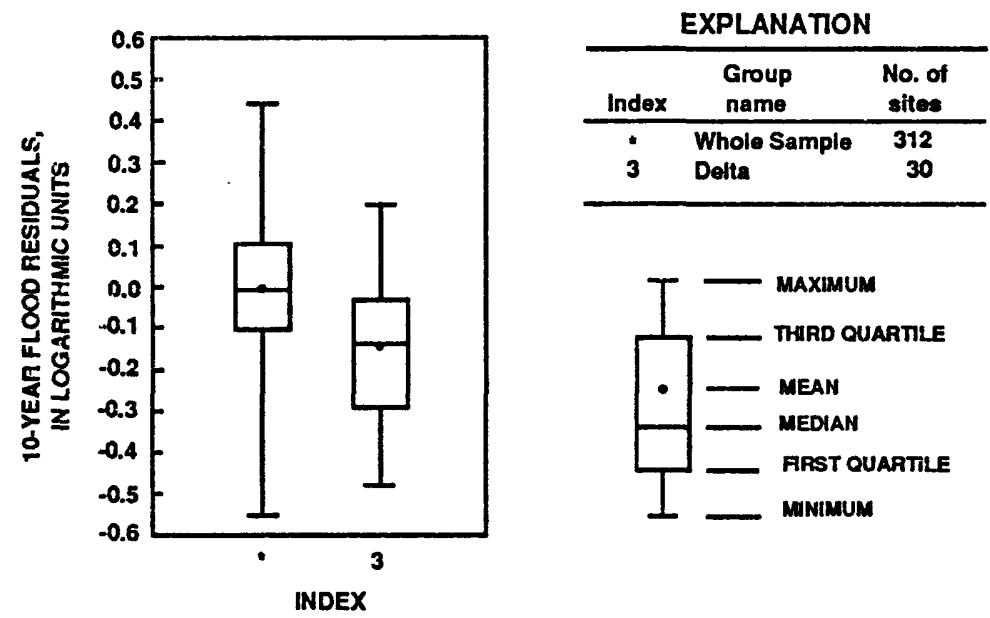

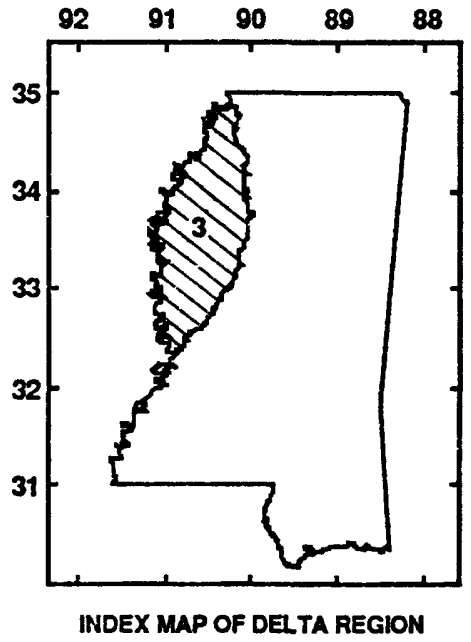

Figure 8. - Characteristics of the 10-year flood residuals for the whole-sample (statewide) group and for the Delta region.

The null hypothesis that the mean of the residuals is equal to the wholesample mean (zero) was rejected at a 1-percent significance level, using the Student's t-test. Significant additional data have not been collected since 1985, because 19 of these 30 sites were discontinued. Therefore, the equations from Landers (1985) are repeated here without alteration. Those equations were computed using OLS regression procedures, and were checked in this 
analysis. The recurrence interval was extended to 500 years using OLS regression procedures. The equations are as follows:

$$
\begin{aligned}
& \mathrm{Q}_{2}=171(\mathrm{~A})^{0.87}(\mathrm{~S})^{0.25}(\mathrm{~L})^{-0.52} \\
& \mathrm{Q}_{5}=192(\mathrm{~A})^{0.93}(\mathrm{~S})^{0.37}(\mathrm{~L})^{-0.54} \\
& \mathrm{Q}_{10}=205(\mathrm{~A})^{0.96}(\mathrm{~S})^{0.42}(\mathrm{~L})^{-0.56} \\
& \mathrm{Q}_{25}=224(\mathrm{~A})^{0.99}(\mathrm{~S})^{0.48}(\mathrm{~L})^{-0.58} \\
& \mathrm{Q}_{50}=232(\mathrm{~A})^{1.00}(\mathrm{~S})^{0.52}(\mathrm{~L})^{-0.57} \\
& \mathrm{Q}_{100}=236(\mathrm{~A})^{1.00}(\mathrm{~S})^{0.57}(\mathrm{~L})^{-0.55} \\
& \mathrm{Q}_{200}=243(\mathrm{~A})^{1.00}(\mathrm{~S})^{0.60}(\mathrm{~L})^{-0.54} \\
& \mathrm{Q}_{500}=249(\mathrm{~A}) 1.00(\mathrm{~S})^{0.64}(\mathrm{~L})^{-0.52}
\end{aligned}
$$

where

$\mathrm{Q}_{\mathrm{T}}$ is the estimated peak discharge, in cubic feet per second, for a recurrence interval of $T$ years;

A is the contributing drainage area, in square miles;

$S$ is the channel slope, in feet per mile, defined as the difference in altitude between points located at 10 and 85 percent of the main channel length divided by the channel length between the two points, as determined from topographic maps; and

$L$ is the main-channel length, in miles, from the point of discharge to the drainage divide as measured in 0.1 mile increments on topographic maps. At a stream junction, the branch draining the largest area is considered the main channel. 


\section{GT800}

Streams outside the Delta were analyzed for flood characteristic homogeneity over the range of drainage areas (fig.9). Comparisons of subgroups of OLS residuals indicate that flood estimates are over-predicted on stream basins larger than about $800 \mathrm{mi}^{2}$ and smaller than about $1 \mathrm{mi}^{2}$ (fig. 10). The subgroup of basins larger than $800 \mathrm{mi}^{2}$ was the most statistically different. When this subgroup of 33 sites was removed, the new whole sample (249 sites) was representative of the small drainage area sites (fig. 11). Equations for sites with drainage areas greater than $800 \mathrm{mi}^{2}$ (GT800) were computed using GLS procedures and are as follows:

$$
\begin{aligned}
& \mathrm{Q}_{2}=131(\mathrm{~A})^{0.97}(\mathrm{~S})^{0.21}(\mathrm{~L})^{-0.47} \\
& \mathrm{Q}_{5}=382(\mathrm{~A})^{0.90}(\mathrm{~S})^{0.22}(\mathrm{~L})^{-0.48} \\
& \mathrm{Q}_{10}=668(\mathrm{~A})^{0.87}(\mathrm{~S})^{0.21}(\mathrm{~L})^{-0.49} \\
& \mathrm{Q}_{25}=1260(\mathrm{~A})^{0.84}(\mathrm{~S})^{0.18}(\mathrm{~L})^{-0.52} \\
& \mathrm{Q}_{50}=1950(\mathrm{~A})^{0.83}(\mathrm{~S})^{0.15}(\mathrm{~L})^{-0.55} \\
& \mathrm{Q}_{100}=2890(\mathrm{~A})^{0.83}(\mathrm{~S})^{0.12}(\mathrm{~L})^{-0.59} \\
& \mathrm{Q}_{200}=4050(\mathrm{~A})^{0.82}(\mathrm{~S})^{0.09}(\mathrm{~L})^{-0.63} \\
& \mathrm{Q}_{500}=6070(\mathrm{~A})^{0.83}(\mathrm{~S})^{0.06}(\mathrm{~L})^{-0.68}
\end{aligned}
$$




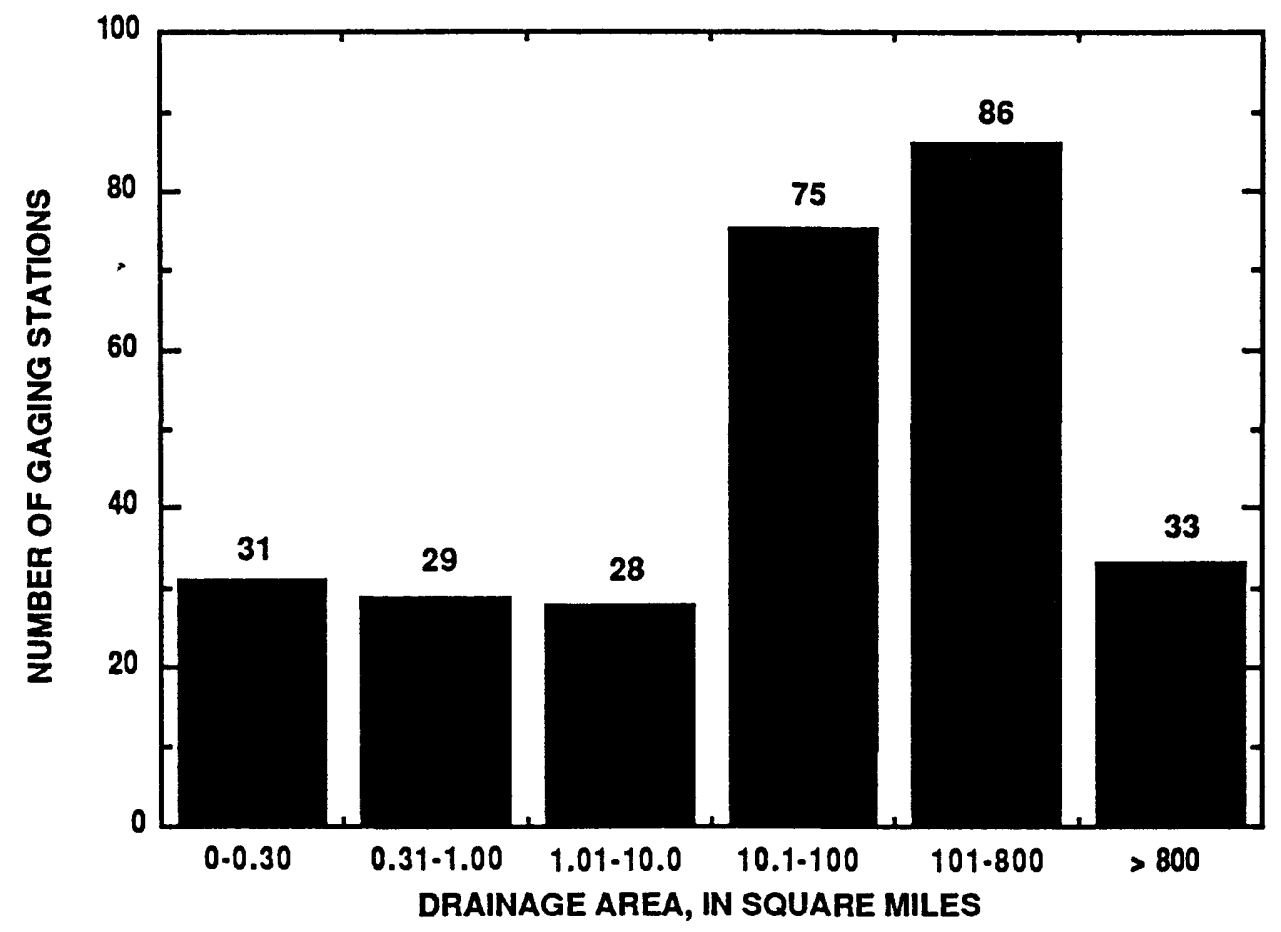

Figure 9.- Distribution of drainage area for 282 gaging stations outside the Delta region.

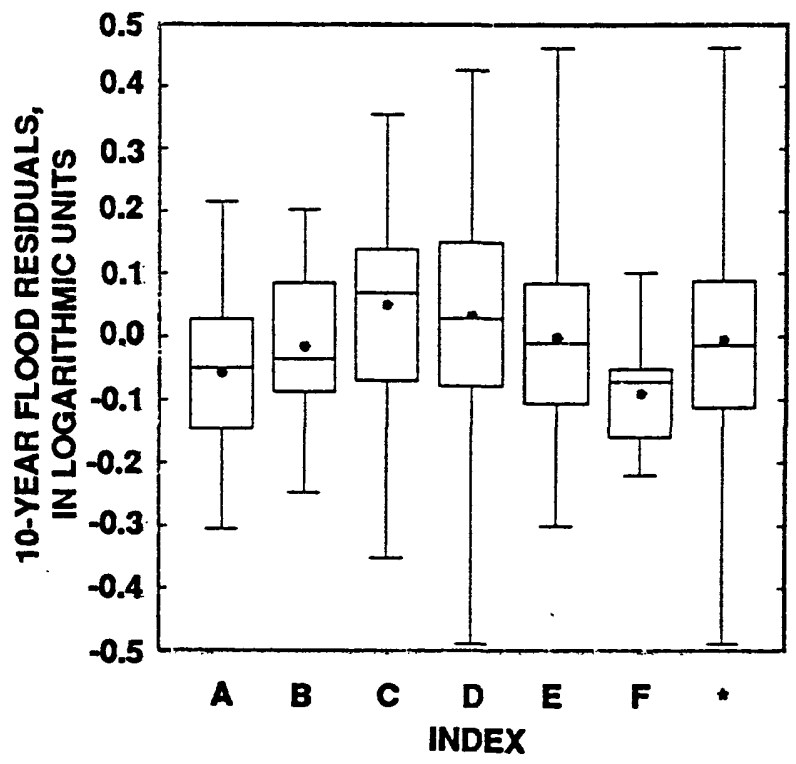

\begin{tabular}{ccc}
\multicolumn{5}{c}{ EXPLANATION } \\
\hline Index & $\begin{array}{c}\text { Drainage area, } \\
\text { In square miles }\end{array}$ & $\begin{array}{c}\text { No. of } \\
\text { sites }\end{array}$ \\
\hline A & $0-0.30$ & 31 \\
B & $0.31-1.00$ & 29 \\
C & $1.01-10.0$ & 28 \\
D & $10.1-100$ & 75 \\
E & $101-800$ & 86 \\
F & $>800$ & 33 \\
$*$ & Whole Sample & 282 \\
\hline
\end{tabular}

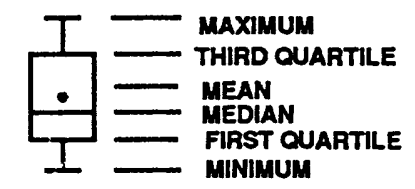

Figure 10.--Characteristics of the 10-year flood residuals for drainage area subgroups and the whole-sample group of sites outside the Delta region. 


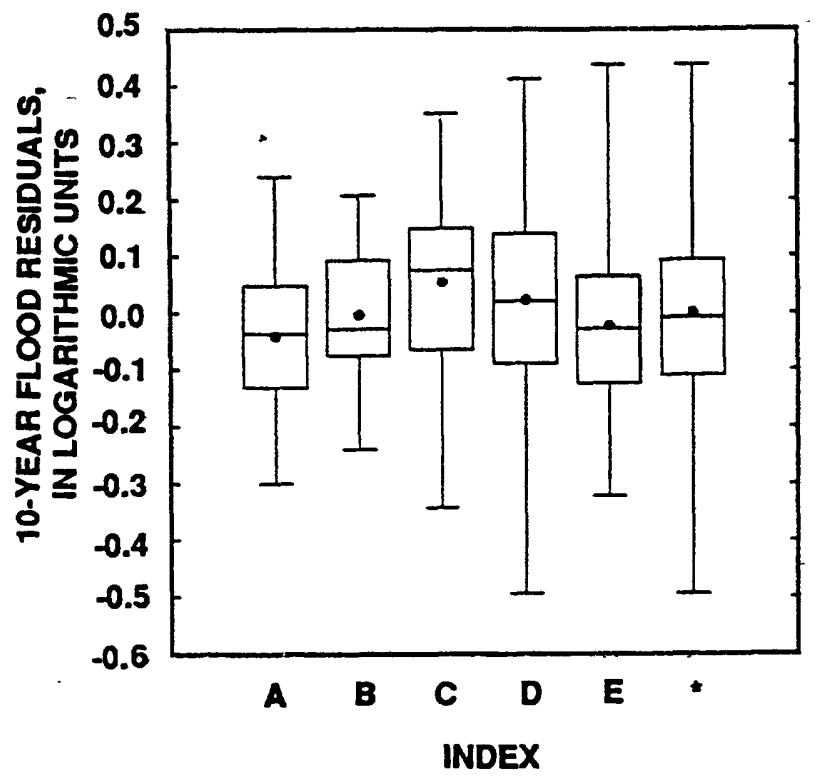

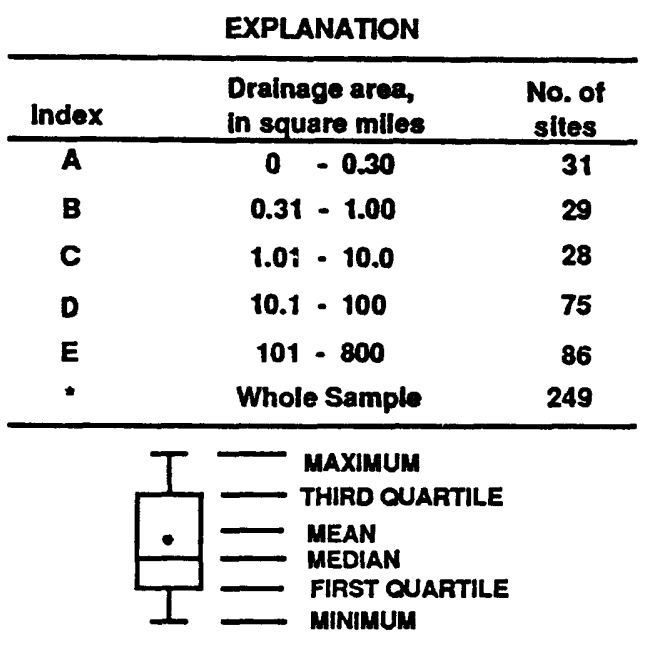

Figure 11.--Characteristics of the 10-year flood residuals for drainage area subgroups and the whole-sample group of sites outside the Delta region having drainage areas less than or equal to 800 square miles.

\section{East}

The whole sample of 249 sites for stream basins outside the Delta region and less than or equal to $800 \mathrm{mi}^{2}$ was also analyzed for flood-characteristic homogeneity. Residuals of the 10-year flood estimate were compared by major basin subgroup. The 10-year flood tended to be over-predicted in the Pearl, Pascagoula, and Mobile River basins (fig. 7). These basins were combined and are referred to as the East region (fig. 12). The small areas of the Hatchie and Tennessee River basins located in Mississippi were included in the East region. The null hypothesis that the mean of the residuals from the 174 sites in the East region is equal to the whole sample mean (zero) was 
rejected at a 1-percent significance level using the Student's t-test. Equations for the East region were computed using GLS procedures and are as follows:

$$
\begin{aligned}
& \mathrm{Q}_{2}=296(\mathrm{~A})^{0.81}(\mathrm{~S})^{0.03}(\mathrm{~L})^{-0.36} \\
& \mathrm{Q}_{5}=406(\mathrm{~A})^{0.84}(\mathrm{~S})^{0.07}(\mathrm{~L})^{-0.35} \\
& \mathrm{Q}_{10}=482(\mathrm{~A})^{0.85}(\mathrm{~S})^{0.09}(\mathrm{~L})^{-0.34} \\
& \mathrm{Q}_{25}=577(\mathrm{~A})^{0.85}(\mathrm{~S})^{0.10}(\mathrm{~L})^{-0.32} \\
& \mathrm{Q}_{50}=648(\mathrm{~A})^{0.85}(\mathrm{~S})^{0.11}(\mathrm{~L})^{-0.31} \\
& \mathrm{Q}_{100}=716(\mathrm{~A})^{0.85}(\mathrm{~S})^{0.11}(\mathrm{~L})^{-0.30} \\
& \mathrm{Q}_{200}=786(\mathrm{~A})^{0.85}(\mathrm{~S})^{0.12}(\mathrm{~L})^{-0.29} \\
& \mathrm{Q}_{500}=874(\mathrm{~A})^{0.85}(\mathrm{~S})^{0.12}(\mathrm{~L})^{-0.28}
\end{aligned}
$$
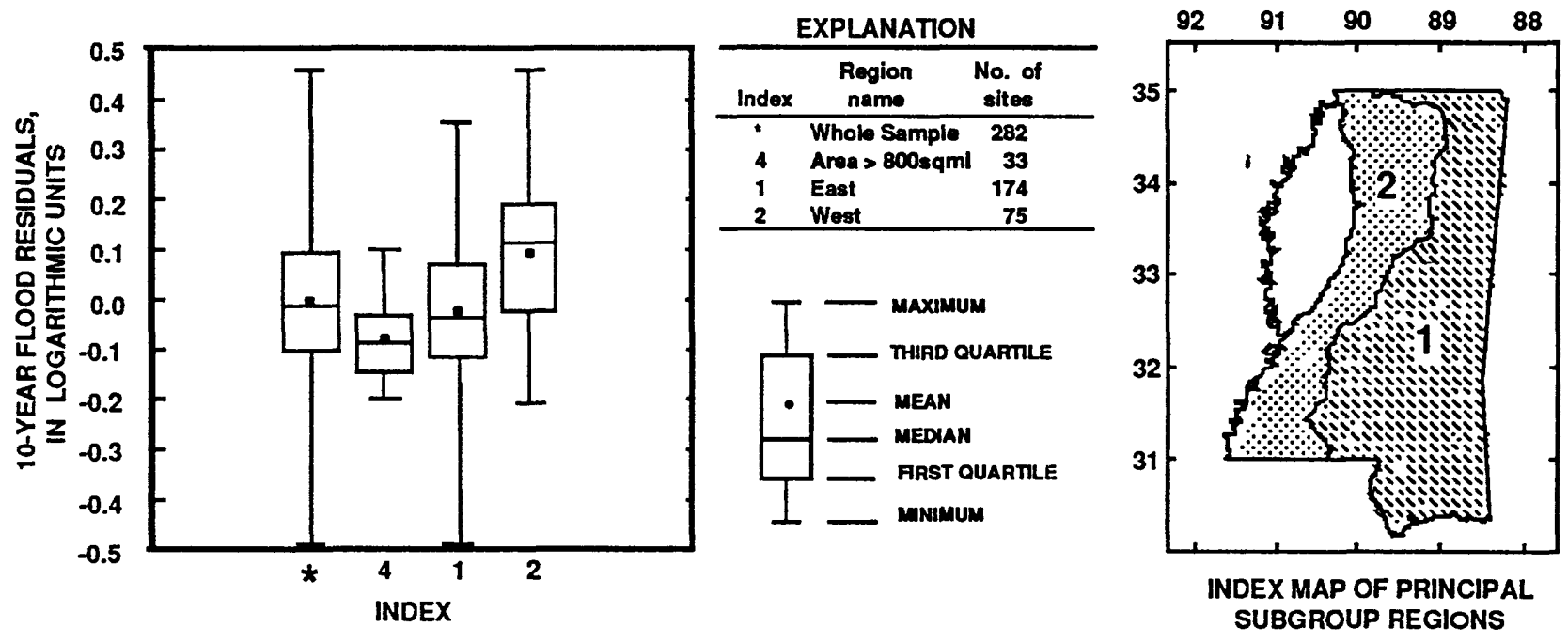

Figure 12.- Characteristics of the 10-year flood residuals for the whole-sample group of sites outside the Delta region and for the principal subgroup regions. 


\section{West}

The 10-year flood tended to be under-predicted for streams in the Yazoo (upstream of the Delta), Big Black, and southwest Mississippi drainage basins when the whole-sample of 249 sites for stream basins outside the Delta region and less than or equal to $800 \mathrm{mi}^{2}$ was analyzed for flood-characteristic homogeneity (fig. 7). These basins were combined and are referred to as the West region of the State (fig. 12). The null hypothesis that the mean of the residuals from the 75 sites in the West region is equal to the whole-sample mean was rejected at a 1-percent significance level using the Student's t-test. Equations for streams in the West region were computed using GLS procedures and are as follows:

$$
\begin{aligned}
& \mathrm{Q}_{2}=66.2(\mathrm{~A})^{0.88}(\mathrm{~S})^{0.51}(\mathrm{~L})^{-0.11} \\
& \mathrm{Q}_{5}=94.7(\mathrm{~A})^{0.93}(\mathrm{~S})^{0.51}(\mathrm{~L})^{-0.15} \\
& \mathrm{Q}_{10}=122(\mathrm{~A})^{0.96}(\mathrm{~S})^{0.49}(\mathrm{~L})^{-0.19} \\
& \mathrm{Q}_{25}=164(\mathrm{~A})^{0.99}(\mathrm{~S})^{0.47}(\mathrm{~L})^{-0.24} \\
& \mathrm{Q}_{50}=197(\mathrm{~A}) 1.00(\mathrm{~S})^{0.45}(\mathrm{~L})^{-0.26} \\
& \mathrm{Q}_{100}=230(\mathrm{~A}) 1.00(\mathrm{~S})^{0.44}(\mathrm{~L})^{-0.25} \\
& \mathrm{Q}_{200}=262(\mathrm{~A}) 1.00(\mathrm{~S})^{0.42}(\mathrm{~L})^{-0.25} \\
& \mathrm{Q}_{500}=305(\mathrm{~A}) 1.00(\mathrm{~S})^{0.41}(\mathrm{~L})^{-0.25}
\end{aligned}
$$

\section{REGIONAL FLOOD-FREQUENCY ESTIMATES FOR URBANIZED STREAMS}

Data have been collected in Mississippi on eight urban streams for which the period of actual flood data has been one of relatively constant urbanization. A preliminary analysis of the flood data on four of these streams in the Jackson area was reported by Wilson (1966). Due to the limited data, equations were not developed for this report, but a comparison was 
made between station frequency discharges (table 1) and discharges computed from the seven-parameter equations developed by Sauer and others in 1983. Those equations were developed using all available U.S. Geological Survey urban drainage basin data throughout the United States. Seven of the Mississippi urban sites were included in this nationwide analysis, which used flood data through the 1977 water year. The seven-parameter equations and definitions, excerpted from Sauer and others (1983), are as follows:

\begin{tabular}{|c|c|c|c|}
\hline & & & $\begin{array}{l}\text { Average } \\
\text { standard } \\
\text { error of } \\
\text { prediction, } \\
\text { in percent } \\
\end{array}$ \\
\hline $\mathrm{UQ}_{2}$ & $=$ & $2.35 \mathrm{~A}^{0.41} \mathrm{SL}^{0.17}(\mathrm{RI} 2+3)^{2.04}(\mathrm{ST}+8)^{-0.65}(13-\mathrm{BDF})^{-0.32} \mathrm{IA}^{0.15} \mathrm{RQ}_{2}{ }^{0.47}$ & \pm 38 \\
\hline $\mathrm{UQ}_{5}$ & $=$ & $2.70 \mathrm{~A}^{0.35} \mathrm{SL}^{0.16}(\mathrm{RI} 2+3)^{1.86}(\mathrm{ST}+8)^{-0.59}(13-\mathrm{BDF})^{-0.31} \mathrm{IA}^{0.11} \mathrm{RQ}^{0.54}$ & \pm 37 \\
\hline $\mathrm{UQ}_{10}$ & $=$ & $2.99 \mathrm{~A}^{0.32} \mathrm{SL}^{0.15}(\mathrm{RI} 2+3)^{1.75}(\mathrm{ST}+8)^{-0.57}(13-\mathrm{BDF})^{-0.30} \mathrm{IA}^{0.09} \mathrm{RQ}_{10} 0.58$ & \pm 38 \\
\hline $\mathrm{UQ}_{25}$ & $=$ & $2.78 \mathrm{~A}^{0.31} \mathrm{SL}^{0.15}(\mathrm{RI} 2+3)^{1.76}(\mathrm{ST}+8)^{-0.55}(13-\mathrm{BDF})^{-0.29} \mathrm{IA}^{0.07} \mathrm{RQ}_{25}{ }^{0.60}$ & \pm 40 \\
\hline $\mathrm{UQ}_{50}$ & $=$ & $2.67 \mathrm{~A}^{0.29} \mathrm{SL}^{0.15}(\mathrm{RI} 2+3)^{1.74}(\mathrm{ST}+8)^{-0.53}(13-\mathrm{BDF})^{-0.28} \mathrm{IA}^{0.06} \mathrm{RQ} \mathrm{Q}^{0.62}$ & \pm 42 \\
\hline $\mathrm{UQ}_{100}$ & & $2.50 \mathrm{~A}^{0.29} \mathrm{SL}^{0.15}(\mathrm{RI} 2+3)^{1.76}(\mathrm{ST}+8)^{-0.52}(13-\mathrm{BDF})^{-0.28} \mathrm{IA}^{0.06} \mathrm{RQ}_{100^{0}} 0.63$ & \pm 44 \\
\hline $\mathrm{UQ}_{500}$ & & $2.27 \mathrm{~A}^{0.29} \mathrm{SL}^{0.16}(\mathrm{RI} 2+3)^{1.86}(\mathrm{ST}+8)^{-0.54}(13-\mathrm{BDF})^{-0.27} \mathrm{IA}^{0.05} \mathrm{RQ}_{500^{0.63}}$ & \pm 49 \\
\hline
\end{tabular}

where

$\mathrm{UQ}_{\mathrm{T}}$ is the urban peak discharge, in cubic feet per second, for the recurrence interval of $T$ years;

A is the contributing drainage area, in square miles;

SL is the main channel slope, in feet per mile, measured between points which are 10 percent and 85 percent of the main channel length upstream from the study site (for sites where SL is greater than 70, 70 is used in the equations); 
RI2 is rainfall intensity, in inches, for the 2-hour 2-year occurrence (U.S. Weather Bureau, 1961).

ST is basin storage, the percentage of the drainage basin occupied by lakes, reservoirs, swamps, and wetlands (inchannel storage of a temporary nature, resulting from detention ponds or roadway embankments, is not included in the computation of ST);

BDF is the basin development factor;

IA is the percentage of the drainage basin occupied by impervious surfaces, such as houses, buildings, streets, and parking lots; and

$\mathbf{R Q}_{\mathrm{T}}$ is the peak discharge, in cubic feet per second, for an equivalent rural drainage basin in the same hydrologic area as the urban basin, and for recurrence interval of $T$ years.

The basin development factor (BDF) describes the conditions of the drainage system. The following description of the BDF and how it is computed is a quotation from Sauer and others (1983).

The most significant index of urbanization that results from this study is a basin development factor (BDF), which , provides a measure of the efficiency of the drainage system. This parameter, which proved to be highly significant in the regression equations, can be easily determined from drainage maps and field inspections of the drainage basin. The basin is first divided into thirds. Then, within each third, four aspects of the drainage system are evaluated and each assigned a code as follows:

1. Channel improvements.--If channel improvements such as straightening, enlarging, deepening, and clearing 
are prevalent for the main drainage channels and principal tributaries (those that drain directly into the main channel), then a code of 1 is assigned. Any or all of these improvements would qualify for a code of 1 . To be considered prevalent, at least 50 percent of the main drainage channels and principal tributaries must be improved to some degree over natural conditions. If channel improvements are not prevalent, then a code of zero is assigned.

2. Channel linings.--If more than 50 percent of the length of the main drainage channels and principal tributaries has been lined with an impervious material, such as concrete, then a code of 1 is assigned to this aspect. If less than 50 percent of these channels is lined, then a code of zero is assigned. The presence of channel linings would obviously indicate the presence of channel improvements as well. Therefore, this is an added factor and indicates a more highly developed drainage system.

3. Storm drains, or storm sewers.--Storm drains are defined as enclosed drainage structures (usually pipes), frequently used on the second tributaries where the drainage is received directly from streets or parking lots. Many of these drains empty into open channels; however, in some basins they empty into channels, enclosed as box or pipe culverts. When more than 50 percent of the secondary tributaries within a subarea (third) consists of storm drains, then a code of 1 is assigned to this aspect; if less than 50 percent of the secondary tributaries consists of storm drains, then a code of zero is assigned. It should be noted that if 50 percent or more of the main drainage channels and principal tributaries are enclosed, then the aspects of channel improvements and channel linings would also be assigned a code of 1 . 
4. Curb-and gutter streets.--If more than 50 percent of a subarea (third) is urbanized (covered by residential, commercial, and/or industrial development), and if more than 50 percent of the streets and highways in the subarea are constructed with curbs and gutters, then a code of 1 would be assigned to this aspect. Otherwise, it would receive a code of zero. Drainage from curb-andgutter streets frequently empties into storm drains.

The above guidelines for determining the various drainage-system codes are not intended to be precise measurements. A certain amount of subjectivity will necessarily be involved. Field checking should be performed to obtain the best estimate. The basin development factor (BDF) is the sum of the assigned codes; therefore, with three subareas (thirds) per basin, and four drainage aspects to which codes are assigned in each subarea, the maximum value for a fully developed drainage system would be 12 . Conversely, if the drainage system were totally undeveloped, then a BDF of zero would result. Such a condition does not necessarily mean that the basin is unaffected by urbanization. In fact, a basin could be partially urbanized, have some impervious area, have some improvement of secondary tributaries, and still have an assigned BDF of zero.

The BDF is fairly easy index to estimate for an existing urban basin. The 50-percent guideline will usually not be difficult to evaluate because many urban areas tend to use the same design criteria, and therefore have similar drainage aspects, throughout. Also, the BDF is convenient for projecting future development. Obviously, full development of the drainage system and maximum urban effects on peaks would occur when BDF $=12$. Projections of full development or intermediate stages of development can usually be obtained from city engineers. 
The nationwide equations were used to estimate the 2-year, 10-year, and 100-year floods for the eight Mississippi urban sites. Four additional basin characteristics needed in these equations are presented in table 3. The nationwide equation estimates are compared with the observed station estimates in figure 13. The comparison is also made on the basis of the rootmean-square error (RMS) of the estimating equation, computed as:

$$
\mathrm{RMS}=\sqrt{(\bar{X})^{2}+\mathrm{S}^{2}}
$$

where $\bar{X}$ is the average error and $S$ is the standard deviation of the error. The root-mean-square error is considered an approximation of the standard error of prediction. Table 4 presents errors of prediction for the group of all eight sites and for the group of five sites in Jackson. For the Jackson sites, the minimum and maximum errors are significantly negative for the 2-year and both positive and negative for the 100-year recurrence interval. Average errors for the 10-year and 100-year recurrence intervals are similar to those reported for adjoining states by Sauer (1986).

Table 3.--Additional basin characteristics for urban streams in Mississippi

[BDF, basin development factor; RI2, rainfall intensity for the 2-hour 2-year occurrence; ST, basin storage; IA, impervious area]

\begin{tabular}{clcccc}
\hline $\begin{array}{c}\text { Station } \\
\text { number }\end{array}$ & \multicolumn{1}{c}{ Station name } & BDF & $\begin{array}{c}\text { RI2 } \\
\text { (inches) }\end{array}$ & $\begin{array}{c}\text { ST } \\
\text { (percent) }\end{array}$ & $\begin{array}{c}\text { IA } \\
\text { (percent) }\end{array}$ \\
\hline 2473047 & Gordon Creek at Hattiesburg & 5 & 2.7 & 0 & 21 \\
2485800 & Eubanks Creek at Jackson & 8 & 2.5 & 0 & 33 \\
2485950 & Town Creek at Jackson & 7 & 2.5 & 0 & 29 \\
2486100 & Lynch Creek at Jackson & 4 & 2.5 & 0 & 27 \\
2486115 & Three Mile Creek at Jackson & 6 & 2.5 & 0 & 29 \\
2486350 & Caney Creek at Jackson & 6 & 2.5 & 2 & 14 \\
7289610 & Bachelor Creek at Canton & 2 & 2.4 & 0 & 10 \\
7290910 & Spanish Bayou at Natchez & 4 & 2.6 & 0 & 27 \\
\hline
\end{tabular}




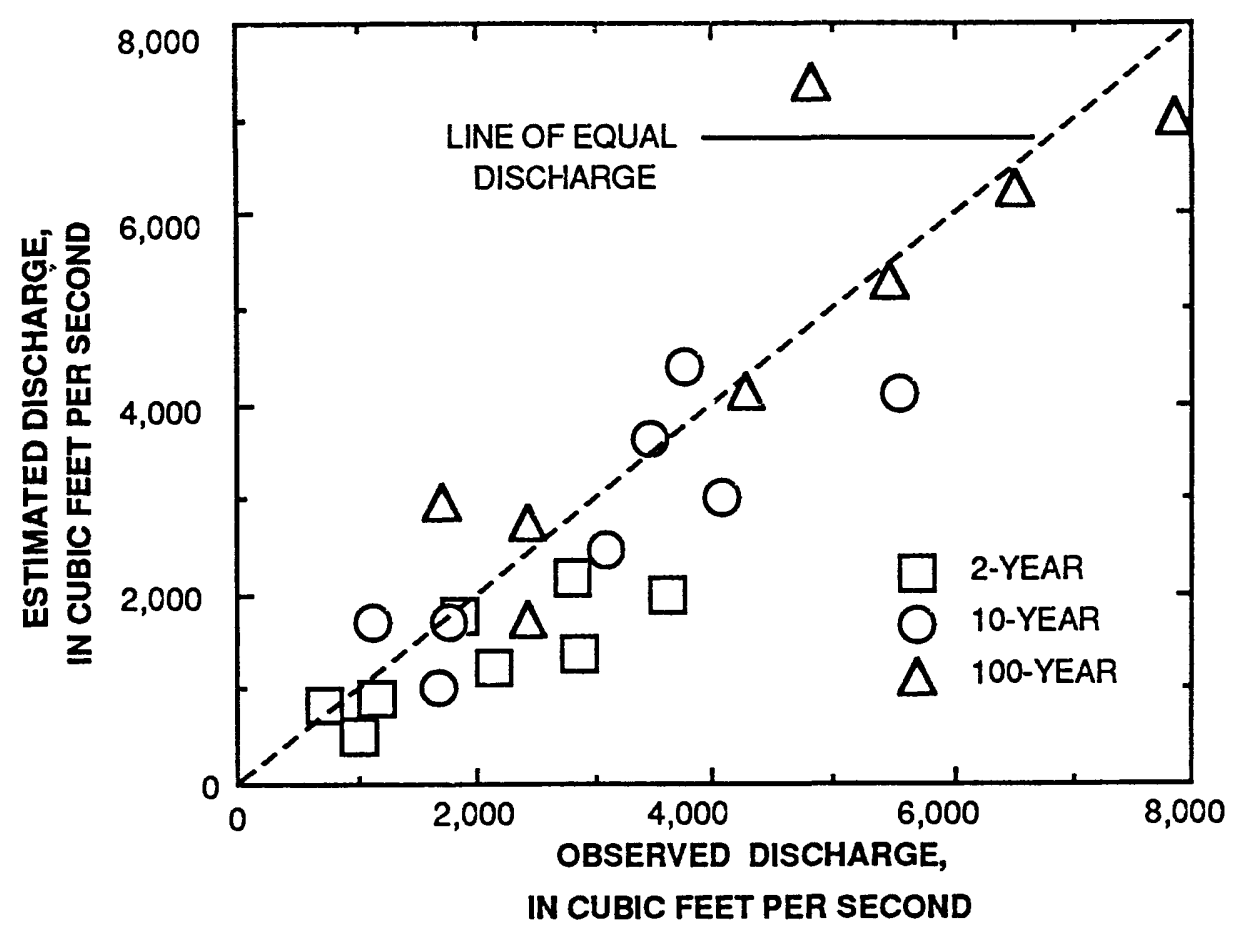

Figure 13.-- Relation of observed 2-year, 10-year, and 100-year urban peak discharge to peak discharge estimated from equation 39,41 , and 44.

Table 4.--Errors of prediction using the seven-parameter nationwide equations for urbanized streams in Mississippi

\begin{tabular}{lcccccc}
\hline & $\begin{array}{c}\text { Recurrence } \\
\text { interval, } \\
\text { in years }\end{array}$ & Minimum & Maximum & Average & $\begin{array}{c}\text { Standard } \\
\text { deviation }\end{array}$ & $\begin{array}{c}\text { Root-mean } \\
\text { square } \\
\text { error }\end{array}$ \\
\hline Sites & & & & & & \\
All & 2 & -52 & +14 & -28 & \pm 24 & \pm 37 \\
(8 sites) & 10 & -39 & +50 & -6 & \pm 29 & \pm 29 \\
& 100 & -29 & +73 & +11 & - \pm 34 & \pm 36 \\
& 2 & -52 & -23 & -42 & \pm 12 & \pm 44 \\
Jackson & 2 & -39 & +16 & -19 & \pm 21 & \pm 28 \\
(5 sites) & 10 & -29 & +54 & +2 & \pm 31 & \pm 31 \\
& 100 & & & & &
\end{tabular}


With the limited data, the Student's t-test, at the 1-percent level of significance, indicates that the negative error for the 2-year recurrence interval is statistically significant when considering only the Jackson sites. However, for all sites combined, no bias in using the seven-parameter equations is proven. The RMS error for the 2-, 10-, and 100-year discharges for all eight sites (table 4 ) is somewhat lower than $\pm 38, \pm 38$, and \pm 44 percent, respectively, as reported in the nationwide study (Sauer and others, 1983); however, when considering only the Jackson sites, the RMS is higher for the 2-year discharge.

The seven-parameter nationwide equations can be used to estimate flood frequencies for an ungaged urbanized stream in Mississippi. However, the limited data, especially in Jackson, indicate that the 2-year to 10-year discharges may be significantly underestimated using the nationwide equations. This emphasizes the need for more peak runoff data for urbanized areas in Jackson and throughout Mississippi.

\section{LIMITATIONS OF REGIONAL FLOOD-FREQUENCY ESTIMATES}

Limitations always exist for an estimate obtained from a regional floodfrequency equation. The most significant known limitations are listed in the following sections. To avoid introducing large errors in estimates, the user should become aware of possible basin projects which may alter flood flows.

\section{Rural Streams}

The following limitations should be observed when using the regional equations in this report for estimating flood-frequency discharges on a rural Mississippi stream because the equations:

- $\quad$ are not considered to be representative for basins outside the range of characteristics (explanatory variables) in the sample set for each region (table 5);

- should not to be used for sites where a significant part of the basin is affected by regulation and (or) channelization; 
- do not apply to estuarine sites near the mouths of coastal streams at which unusual flood discharges result from hurricane tides flowing into or out of storage;

- $\quad$ should be used with caution near the mouths of streams draining into larger streams because the larger stream may cause critical stages and discharges at the recurrence interval in question; or

- may not be fully representative of the steep loess "bluff" hills, bordering parts of the Delta, and the flat coastal region of the State, extending roughly $20 \mathrm{mi}$ inland from the Gulf of Mexico, due to the limited data in these areas.

Table 5.--Characteristics of explanatory variables used in regression calculations for basins in the East and West regions with areas less than or equal to 800 square miles, basins in the Delta, and basins in the East or West regions with areas greater than 800 square miles (GT800)

[Area, in square miles; Channel slope, in feet per mile; Channel length, in miles]

\begin{tabular}{|c|c|c|c|c|c|}
\hline Region & $\begin{array}{c}\text { Basin } \\
\text { characteristic }\end{array}$ & Mean & Median & Minimum & Maximum \\
\hline East & $\begin{array}{l}\text { Area } \\
\text { Channel slope } \\
\text { Channel length }\end{array}$ & $\begin{array}{r}146 \\
25.4 \\
23.0\end{array}$ & $\begin{array}{l}40.3 \\
10.2 \\
12.2\end{array}$ & $\begin{array}{l}0.10 \\
1.5 \\
0.4\end{array}$ & $\begin{array}{l}799 \\
170 \\
123\end{array}$ \\
\hline West & $\begin{array}{l}\text { Area } \\
\text { Channel slope } \\
\text { Channel length }\end{array}$ & $\begin{array}{r}131 \\
28.8 \\
18.2\end{array}$ & $\begin{array}{l}35.3 \\
10.9 \\
12.3\end{array}$ & $\begin{array}{l}0.06 \\
2.3 \\
0.3\end{array}$ & $\begin{array}{l}654 \\
192 \\
70.7\end{array}$ \\
\hline Delta & $\begin{array}{l}\text { Area } \\
\text { Channel slope } \\
\text { Channel length }\end{array}$ & $\begin{array}{l}389 \\
2.1 \\
65.7\end{array}$ & $\begin{array}{r}300 \\
1.0 \\
56.0\end{array}$ & $\begin{array}{l}0.11 \\
0.4 \\
0.5\end{array}$ & $\begin{array}{c}1,170 \\
10.6 \\
269\end{array}$ \\
\hline GT800 & $\begin{array}{l}\text { Area } \\
\text { Channel slope } \\
\text { Channel length }\end{array}$ & $\begin{array}{c}2,368 \\
2.1 \\
134\end{array}$ & $\begin{array}{c}1,650 \\
1.8 \\
110\end{array}$ & $\begin{array}{r}831 \\
0.7 \\
49.1\end{array}$ & $\begin{array}{c}6,590 \\
4.4 \\
338\end{array}$ \\
\hline
\end{tabular}




\section{Urbanized Streams}

The seven-parameter nationwide equations for estimating floodfrequency discharges on an urbanized Mississippi stream apply when the basin and climatic variables are within the following ranges:

- A -0.2 to $100 \mathrm{mi}^{2}$

- SL -3.0 to $70 \mathrm{ft} / \mathrm{mi}$

- RI2 -0.2 to 2.8 in

- ST - 0 to 11 percent

- BDF - 0 to 12

- IA - 3 to 50 percent

The maximum value for SL for use in the equations is $70 \mathrm{ft} / \mathrm{mi}$; although numerous drainage basins used in the development of the equations had SL values up to $500 \mathrm{ft} / \mathrm{mi}$. If values for the variables are outside these ranges, the standard error may be considerably higher than for sites where all variables are within the specified range (Sauer and others, 1983).

\section{SUMMARY}

This report provides techniques for estimating the magnitude of floods with recurrence intervals from 2 to 500 years for streams in Mississippi. Estimates of flood magnitude are presented for 330 streamflow-gaging stations. Flood-frequency discharges for seven of the eleven streamflowgaging stations on the Pearl River, which were agreed upon in 1980 by the U.S. Geological Survey and the U.S. Army Corps of Engineers, Mobile District, are included. A graphical relation of flood-frequency discharge to drainage area for the Pearl River main stem, with an adjustment for basin shape, is also presented. 
Regression analyses were used to define relations between floodfrequency characteristics and explanatory drainage basin variables for 282 rural streamflow-gaging stations, which are representative of similar streams in a specific class or region. To improve accuracy of the regression equations, the State was divided into four subgroups, three defined by geographic boundaries and one by drainage area magnitude. Generalized-least-squares regression, which defines more accurate estimates of regression coefficients and model error than ordinary-least-squares regression, was used in the analyses of three subgroups. The Delta subgroup was analyzed using ordinary-least-squares regression, and because relatively little data have been collected since 1985, previously published equations are presented with extension to 500 years. The regression analyses indicated that size of drainage area, slope of the main channel, and length of the main channel were the most significant basin characteristics that affect the magnitude and frequency of floods for all four subgroups. Regression equations presented for the four subgroups may be used to estimate the magnitude and frequency of floods for ungaged rural stream sites in the State. If the drainage area at an ungaged site is within 50 percent of the drainage area at a gaged site on the same stream, the flood-frequency estimate can be extrapolated using the flood frequency at the gaged site weighted with the regional estimate at the ungaged site using equation 6.

Only eight sites were available for which the period of record was one of relatively constant urbanization. For these sites, a comparison was made between frequency discharges computed from the record and discharges computed from the seven-parameter nationwide equations described previously. When considering only the five sites in Jackson, the 2-year discharge appears to be under-estimated using the nationwide equations; however, for all sites combined, no bias in using the nationwide equations is proven. Therefore, the seven-parameter nationwide equations are presented and can be used to estimate the magnitude and frequency of floods for an ungaged urban stream in the State. 


\section{REFERENCES}

Barnes, H.H., Jr., and Golden, H.G., 1966, Magnitude and frequency of floods in the United States, Part 2B, South Atlantic Slope and Eastern Gulf of Mexico Basins, Ogeechee River to Pearl River: U.S. Geological Survey Water-Supply Paper 1674, 409 p.

Bobee, Bernard, 1973, Sample error of T-year events computed by fitting a Pearson type 3 distribution, Water Resources Research, v. 9, chap. 5, p. 1264-1270.

Colson, B.E., 1986, Comparison of flood frequency estimates from synthetic and observed data on small drainage areas in Mississippi: U.S. Geological Survey Water-Resources Investigations Report 86-4034, 23 p.

Colson, B.E., and Hudson, J.W., 1976, Flood frequency of Mississippi streams: Mississippi State Highway Department, RO-76-014-PR, 34 p.

Fisher, R.A., 1931, The moments of the distribution of normal samples of measures of departure from normality: Proceedings of the Royal Society of London, v. 130, p. 16-28.

Hardison, C.H., 1969, Accuracy of streamflow characteristics: U.S. Geological Survey Professional Paper 650-D, p. D210-D214.

---1971, Prediction error of regression estimates of streamflow characteristics at ungaged sites: U.S. Geological Survey Professional Paper 750-C, p. 228-236.

Interagency Advisory Committee on Water Data, 1982, Bulletin 17B, Guidelines for determining floodflow frequency: U.S. Geological Survey, Office of Water Data Coordination, Reston, Va., 28 p.

Kite, G.W., 1988, Frequency and risk analysis in hydrology: Water Resources Publications, Denver, Colo., chap. 9, 10, and 15. 
Landers, M.N., 1985, Floodflow frequency of streams in the alluvial plain of the lower Mississippi River in Mississippi, Arkansas, and Louisiana: U.S. Geological Survey Water-Resources Investigations Report 85-4150, $21 \mathrm{p}$.

-1989, Regional skew coefficients for flood-frequency analysis of Mississippi streams: Proceedings of 19th Mississippi Water Resources Conference, March 14-15, 1989, Jackson, Miss., p. 66-70.

Lepkin, W.D., DeLapp, M.M., Kirby, W.H., and Wilson, T.A., 1981, WATSTORE User's Guide, Volume 4, U.S. Geological Survey Open-File Report 79-1336-I, p. C-1 to C-57.

Patterson, J.L., 1964, Magnitude and frequency of floods in the United States, Part 7, Lower Mississippi River Basin: U.S. Geological Survey WaterSupply Paper 1681, 636 p.

Sauer, V.B., 1986, New studies of urban flood frequency in the southeastern United States in Hydraulics and Hydrology, Transportation Research Record 1073: Transportation Research Board, National Research Council, p. 10-15.

Sauer, V.B., Thomas, W.O., Jr., Stricker, V.A, and Wilson, K.V., Sr., 1983, Flood characteristics of urban watersheds in the United States: U.S. Geological Survey Water-Supply Paper 2207, 63 p.

Stedinger, J.R., and Cohn, T.A., 1986, Flood frequency analysis with paleoflood information: Water Resources Research, v. 22, no. 5, p. 785-793.

Stedinger, J.R., and Tasker, G.D., 1985, Regional hydrologic analysis 1: ordinary, weighted and generalized least squares compared: Water Resources Research, vol. 21, no. 9, p. 1421-1432.

----1986, Regional hydrologic analysis 2: model error estimators, estimation of sigma and log-Pearson type 3 distribution: Water Resources Research, v. 22, no. 10, p. 1487-1499. 
Tasker, G.D., and Stedinger, J.R., 1986, Regional skew with weighted LS regression: Journal of Water Resources Planning and Management, v. 112 , no. 2, p. 225-237.

-1989, An operational GLS model for hydrologic regression: Journal of Hydrology, v. 111, p. 361-375.

Thomas, D.M., and Benson, M.A., 1970, Generalization of streamflow characteristics from drainage-basin characteristics: U.S. Geological Survey Water-Supply Paper 1975, 55 p.

Thomas, W.O., Jr., 1987, Comparison of flood-frequency estimates based on observed and model-generated peak flows: Proceedings of the International Symposium on Flood Frequency and Risk Analyses, May 14-17, 1986, Louisiana State University, Baton Rouge, La., p. 149-161.

Tung, Y.K., and Mays, L.W., 1981, Generalized skew coefficients for flood frequency analysis: Water Resources Bulletin, v. 17, no. 2, p. 262-269.

U.S. Weather Bureau, 1961, Rainfall frequency atlas of the United States: U.S. Department of Commerce Technical Paper no. 40,61 p.

Wallis, J.R., Matalas, N.C., and Slack, J.R., 1974, Just a moment!: Water Resources Research, v. 10, no. 2, p. 217-219.

Wax, C.L., 1982, Atlas of the climatic water balance in Mississippi: normals and variability, 1951-80: Water Resources Research Institute Bulletin, Mississippi State University, $82 \mathrm{p}$.

Wilson, K.V., Sr., 1966, Flood frequency of streams in Jackson, Mississippi: U.S. Geological Survey open-file report, 6 p.

Wilson, K.V., Sr., and Trotter, I.L., 1961, Floods in Mississippi, magnitude and frequency: U.S. Geological Survey open-file report, 326 p. 


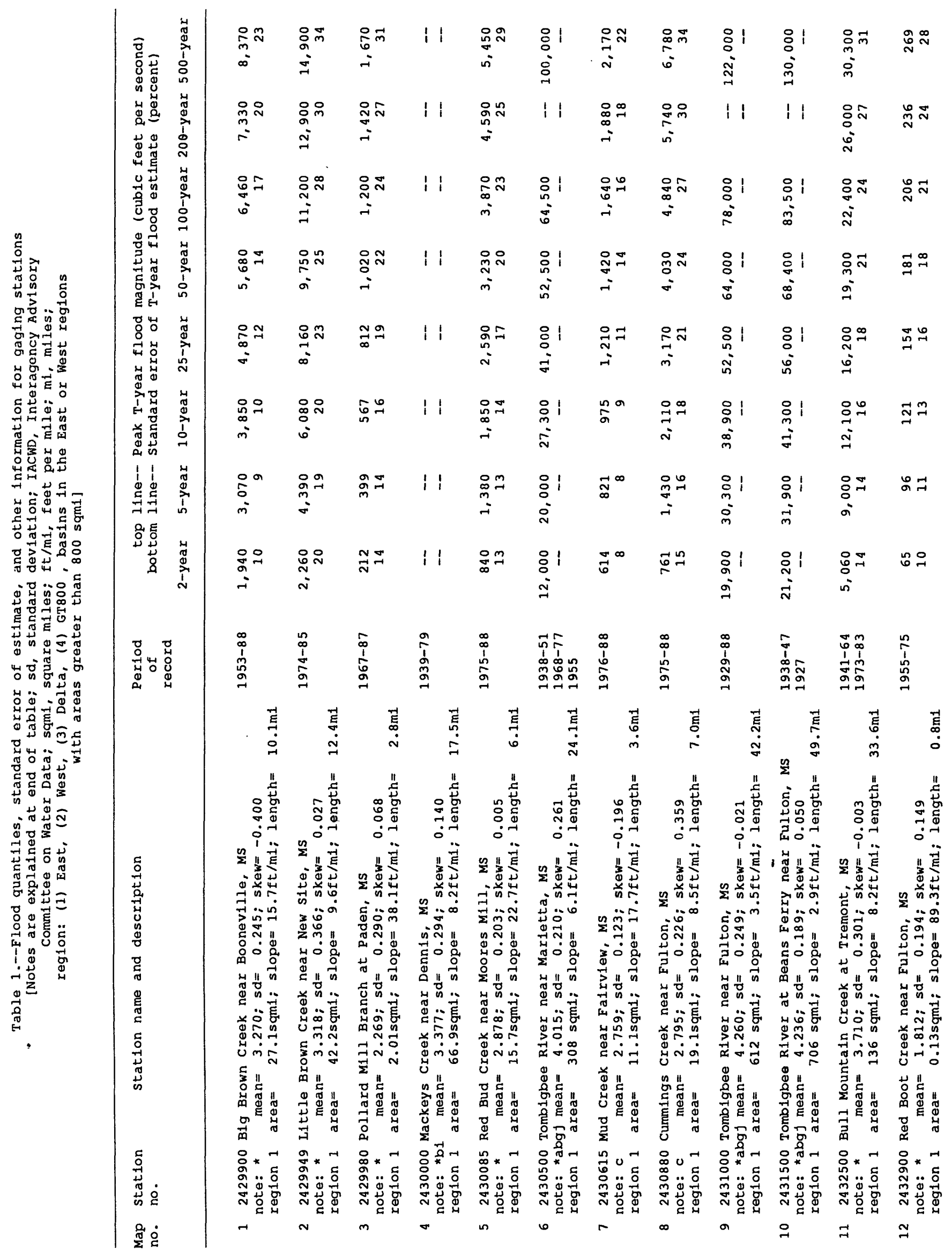




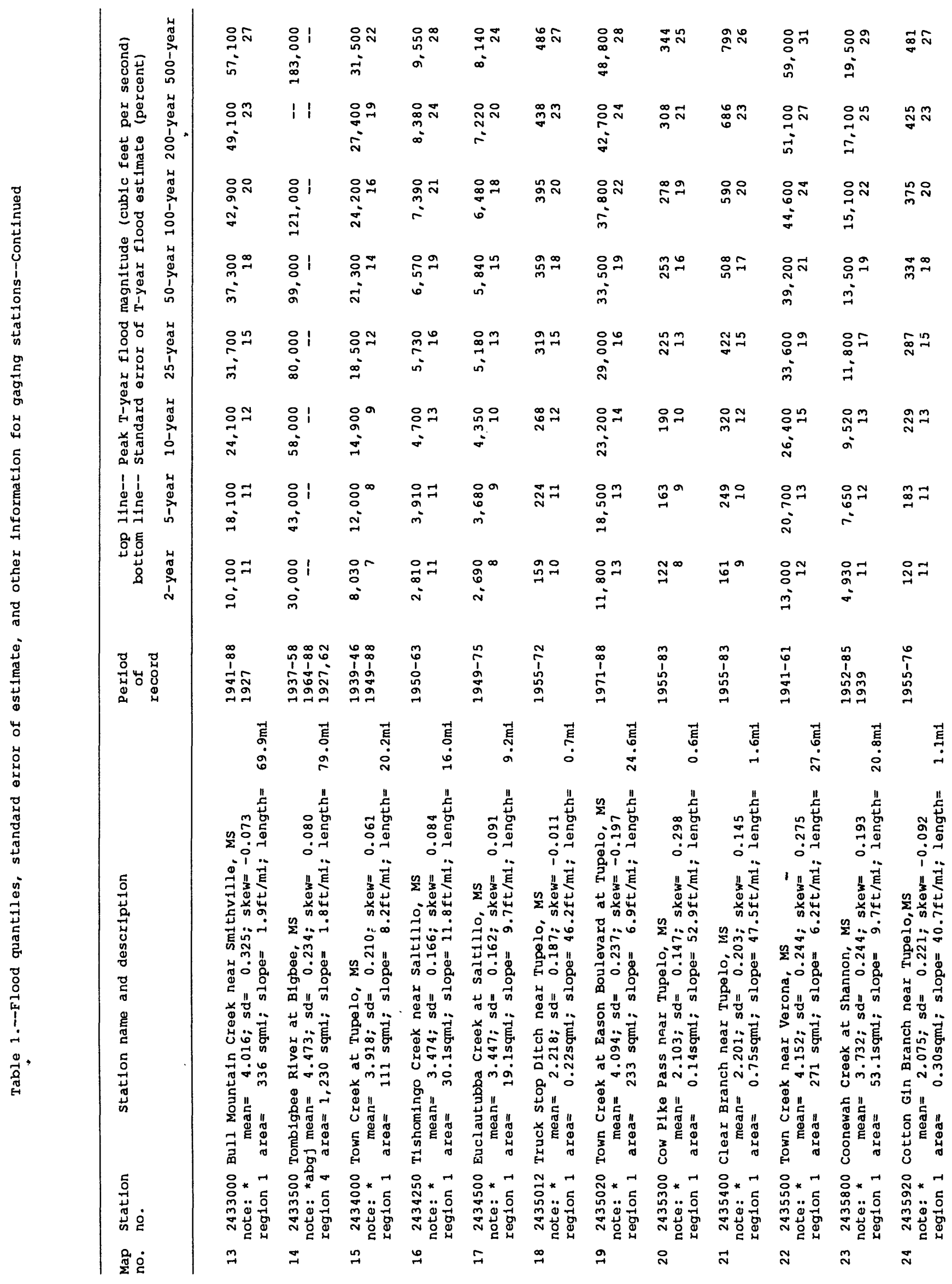




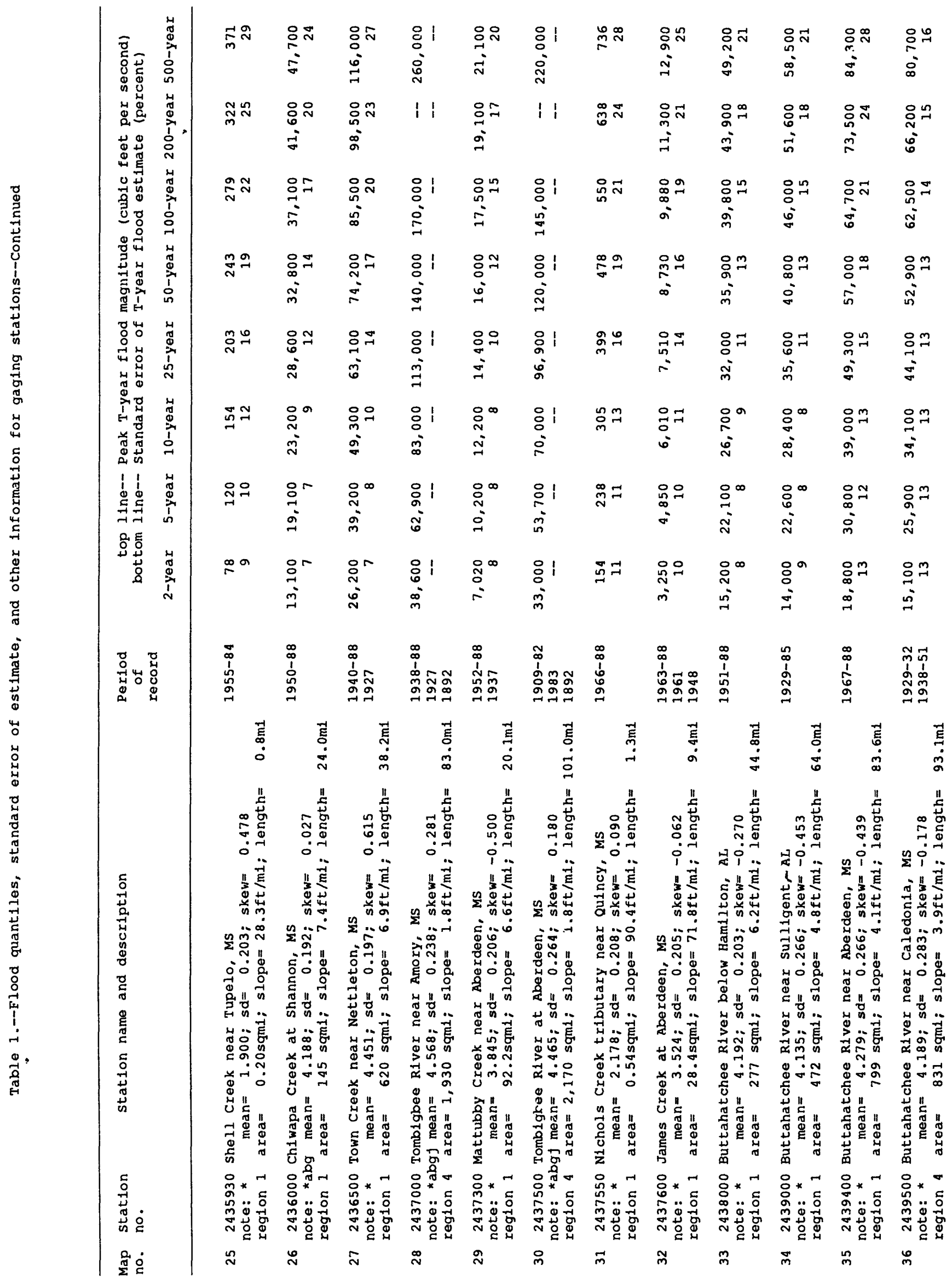




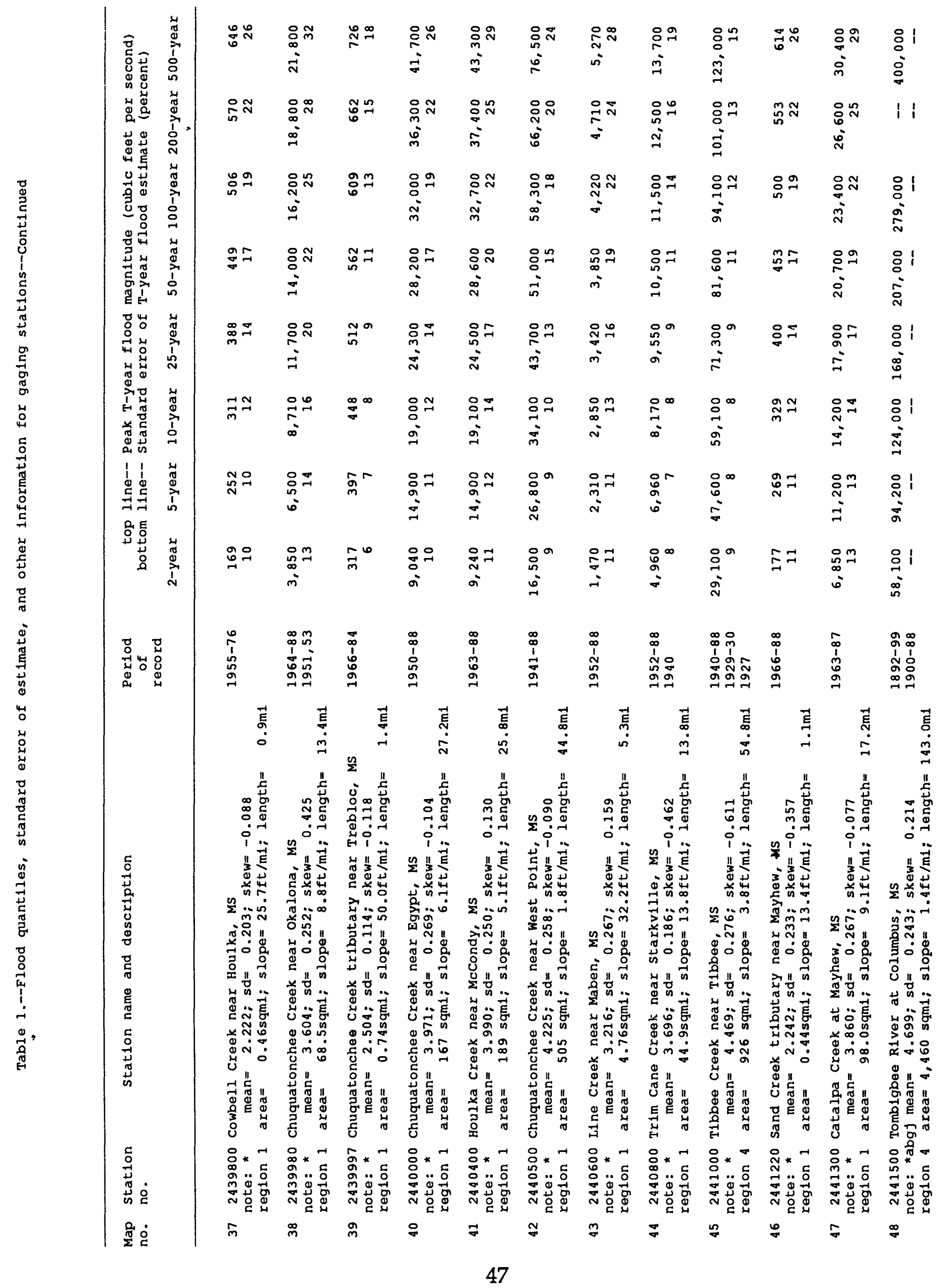




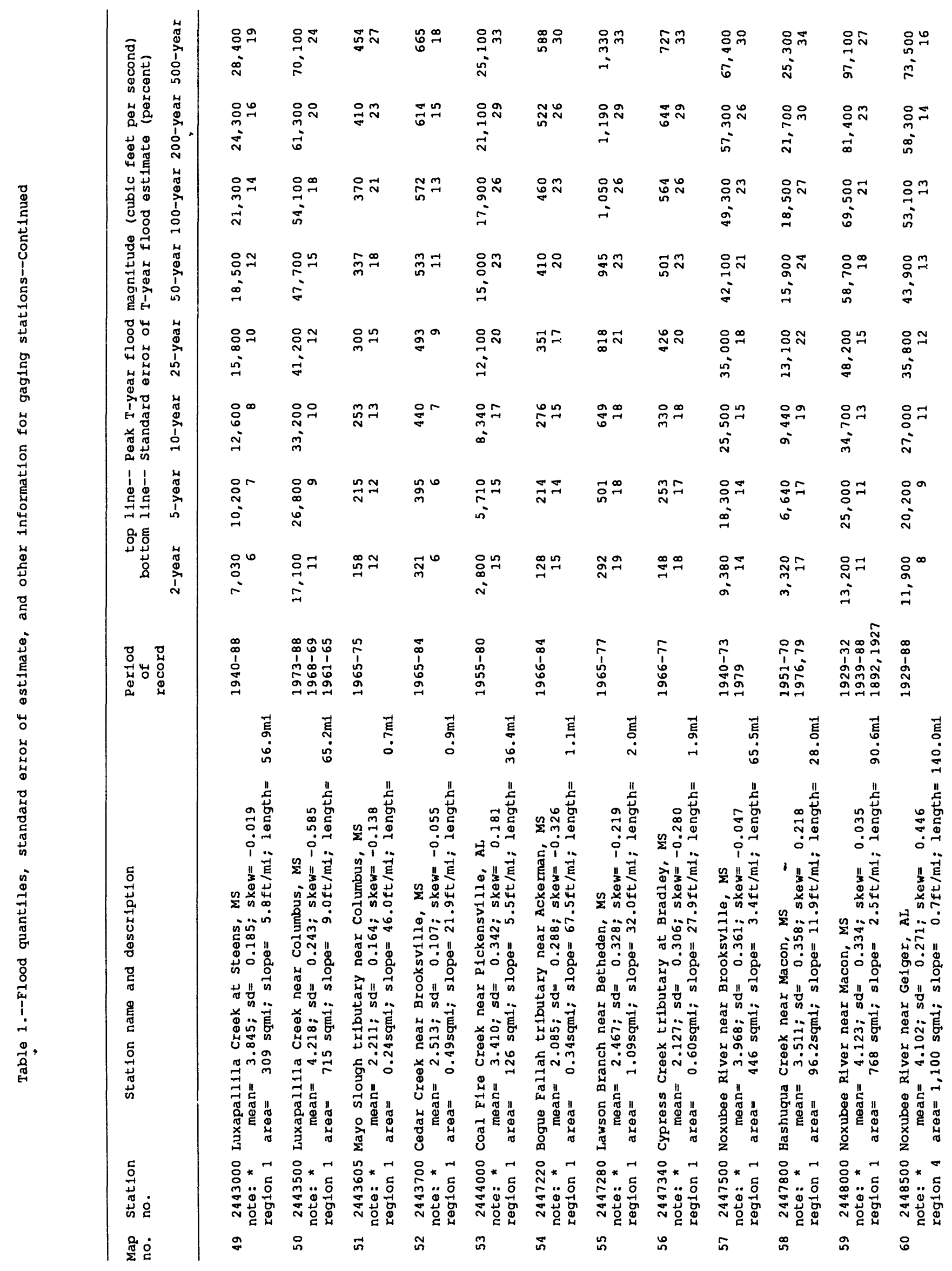




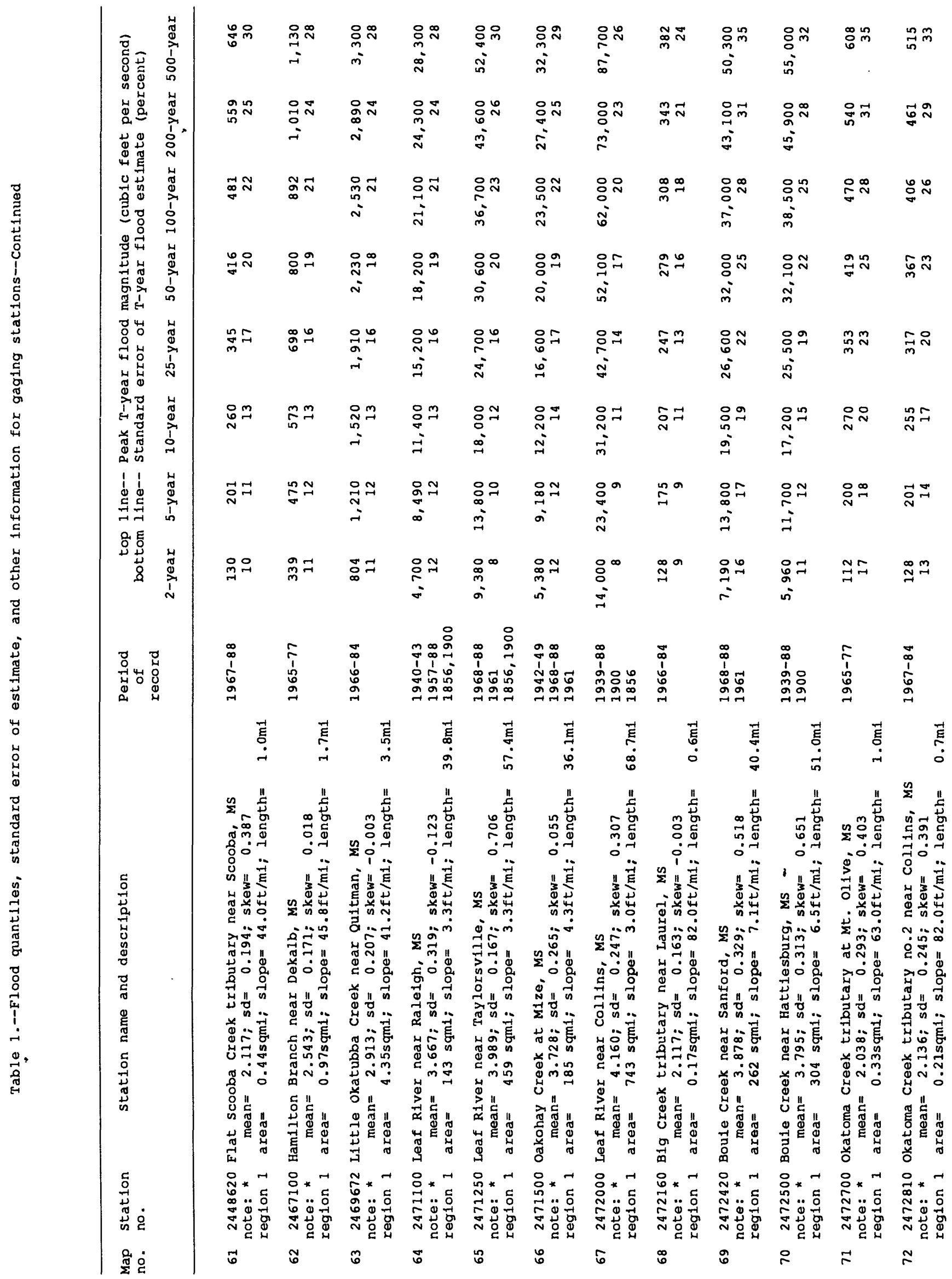




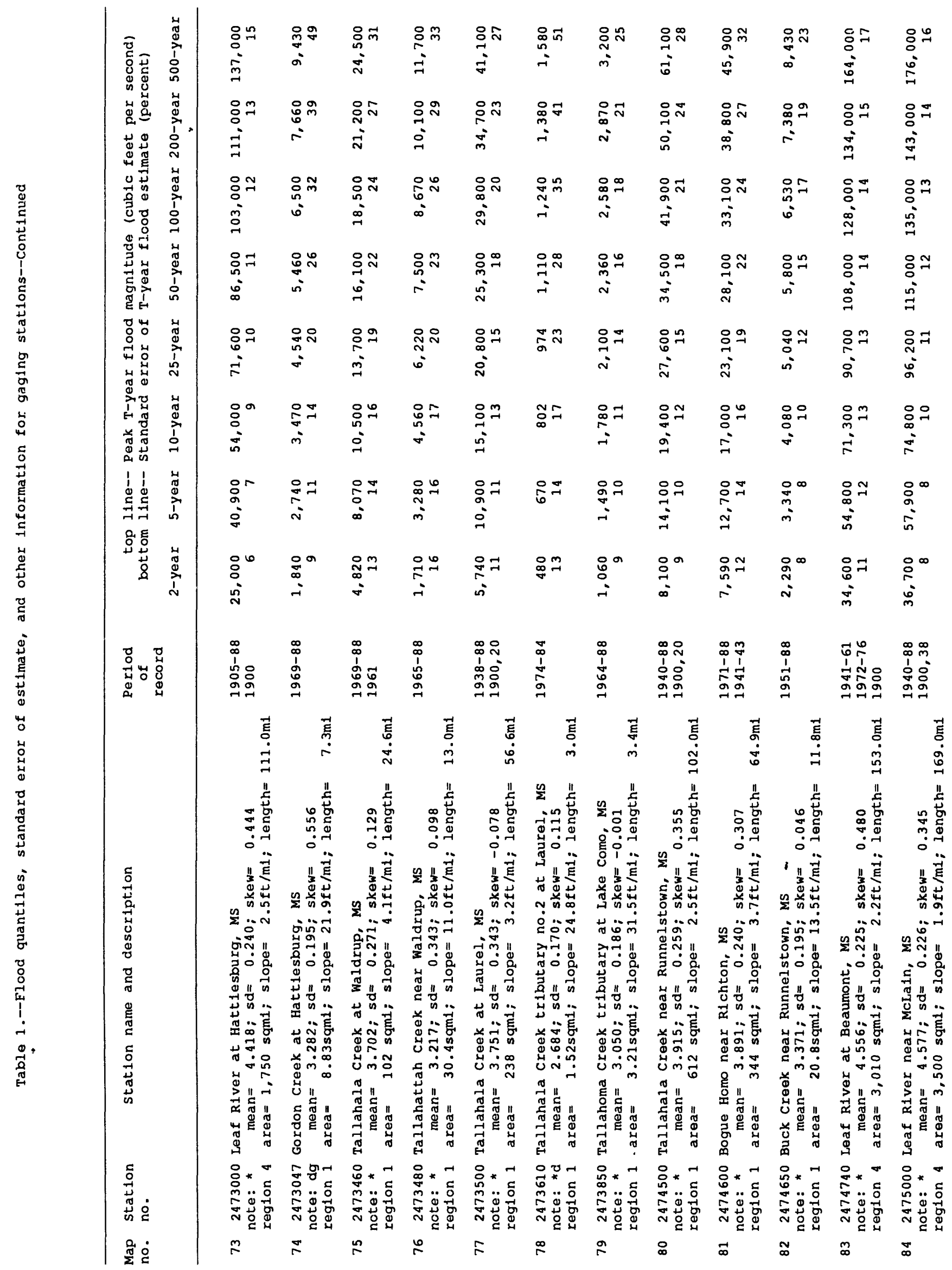




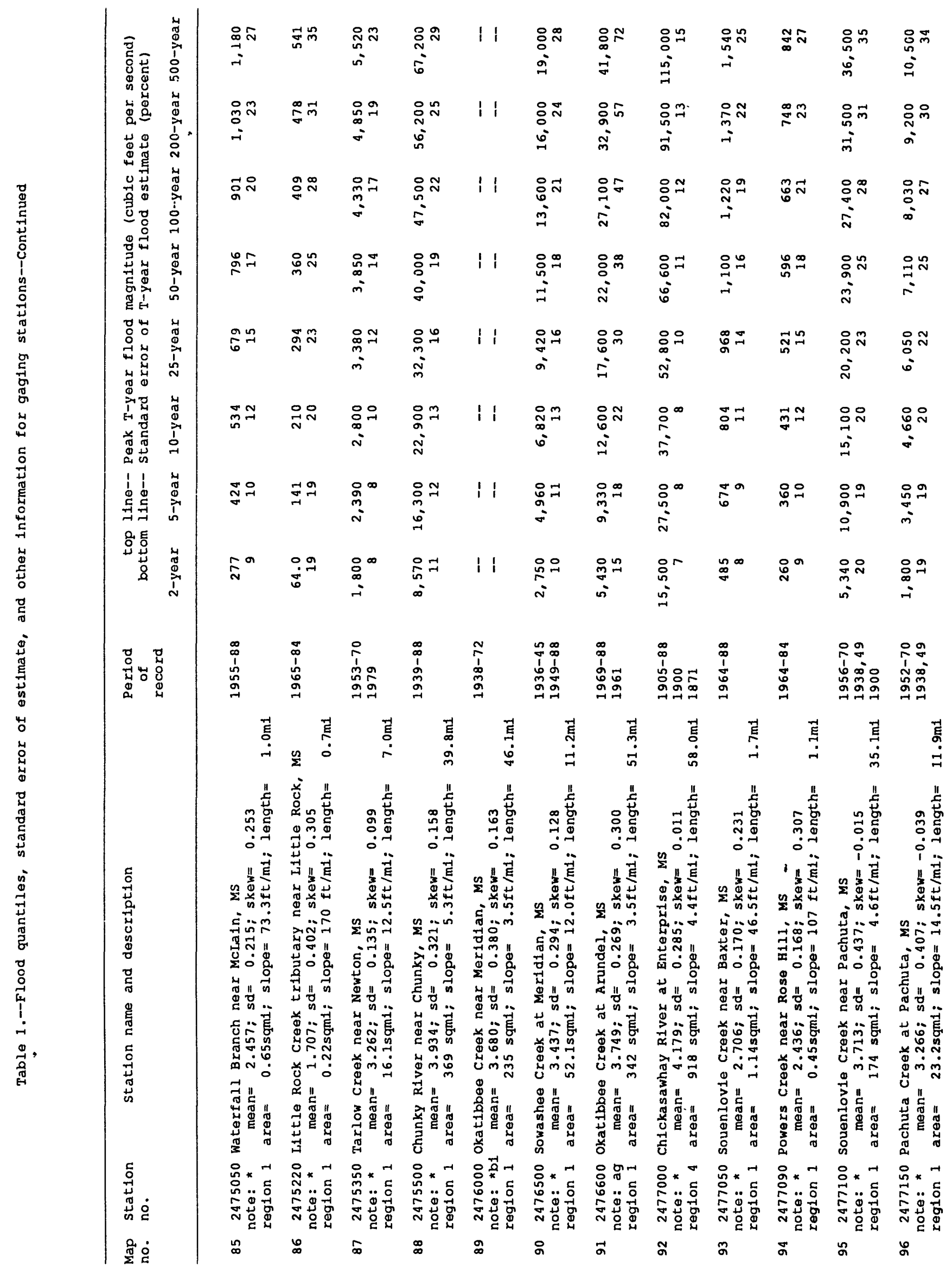




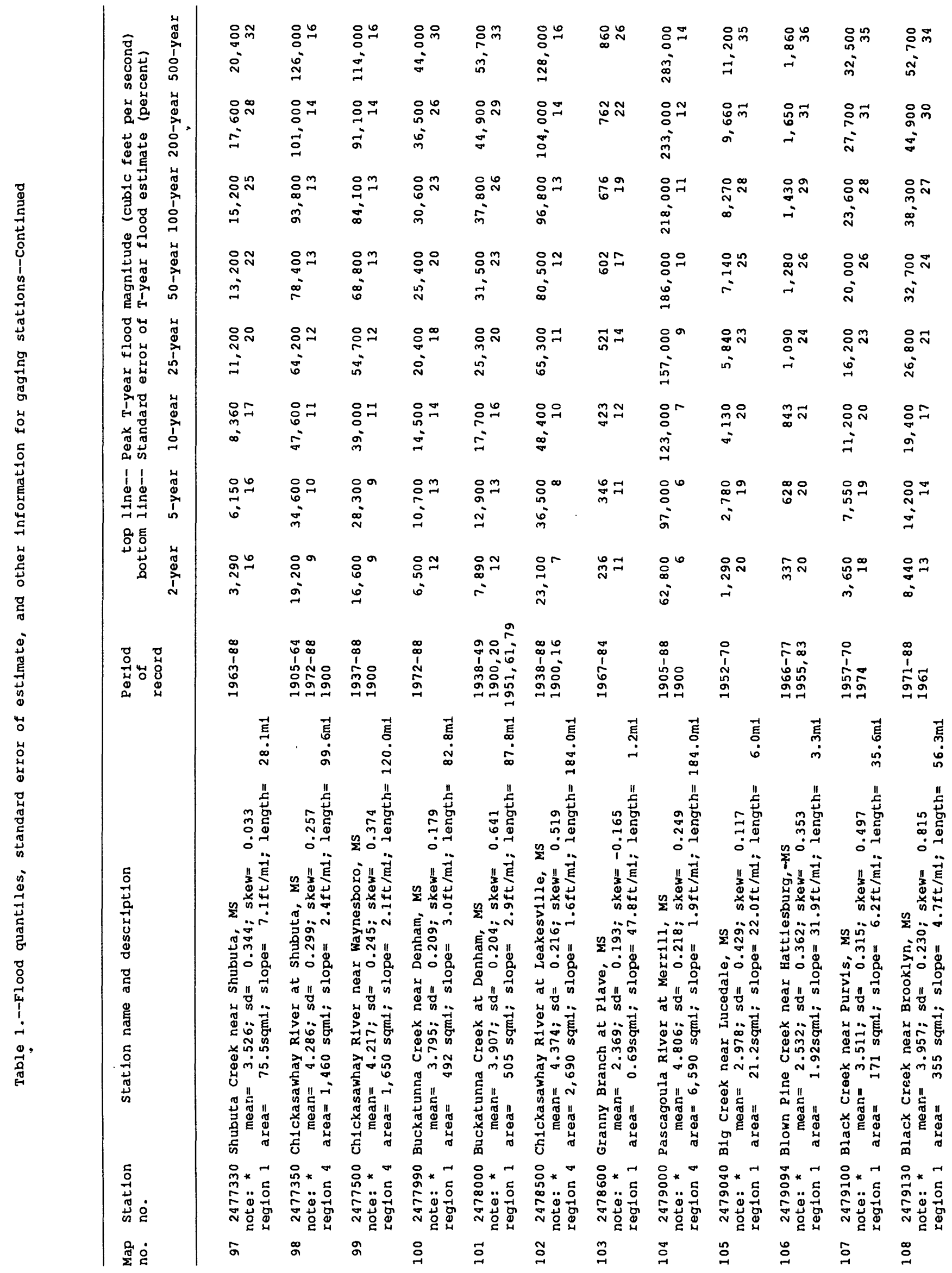




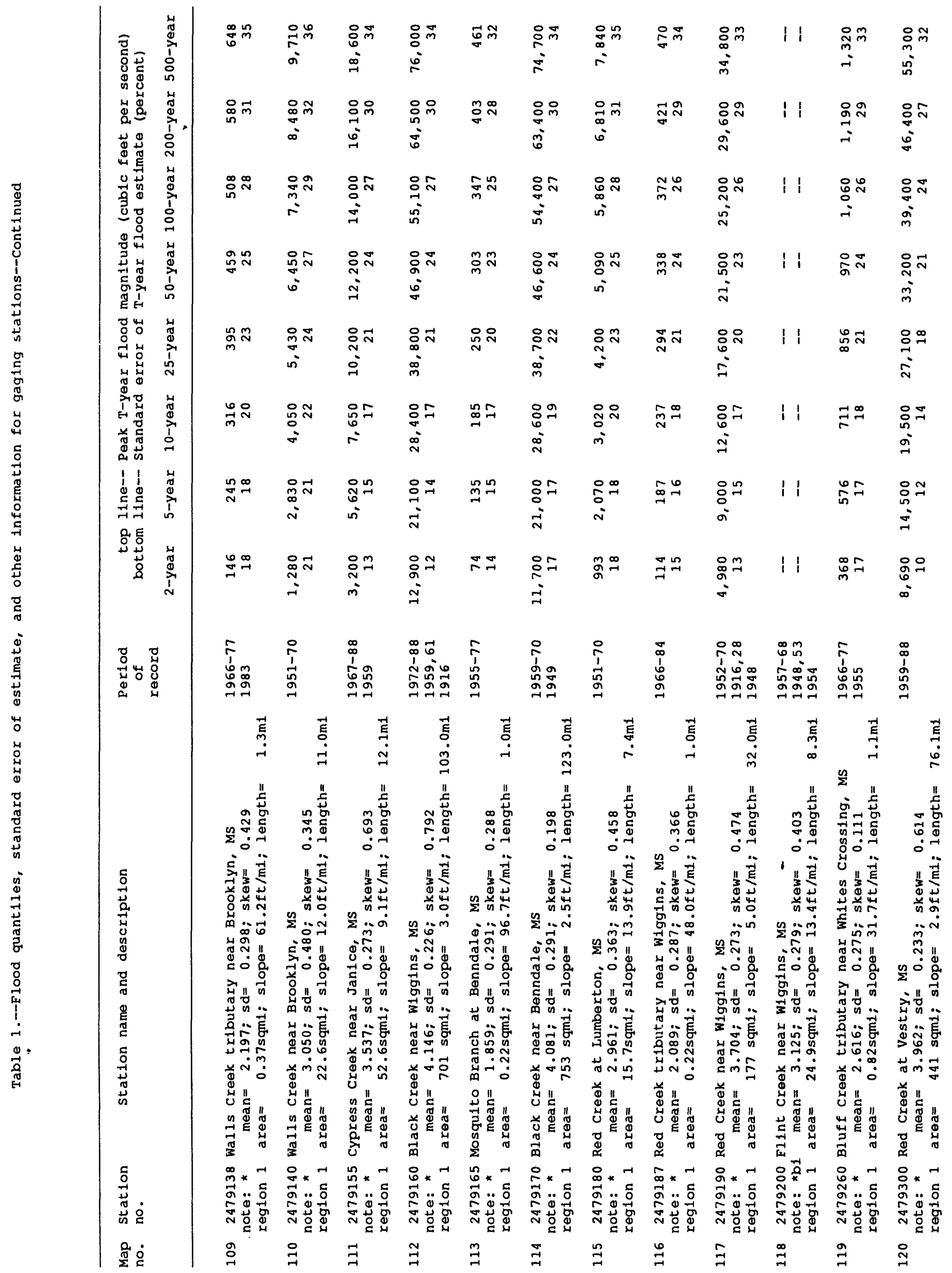




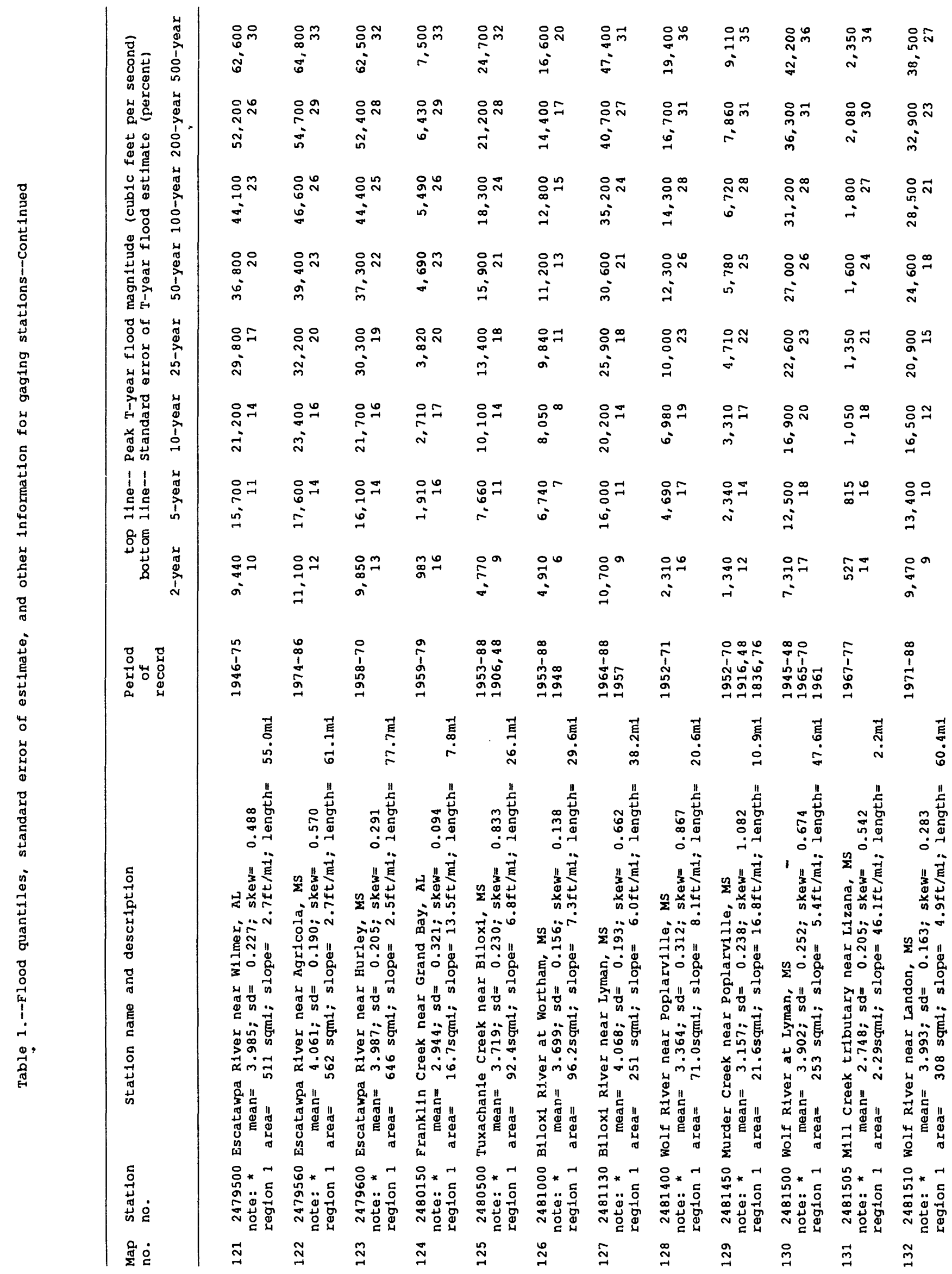




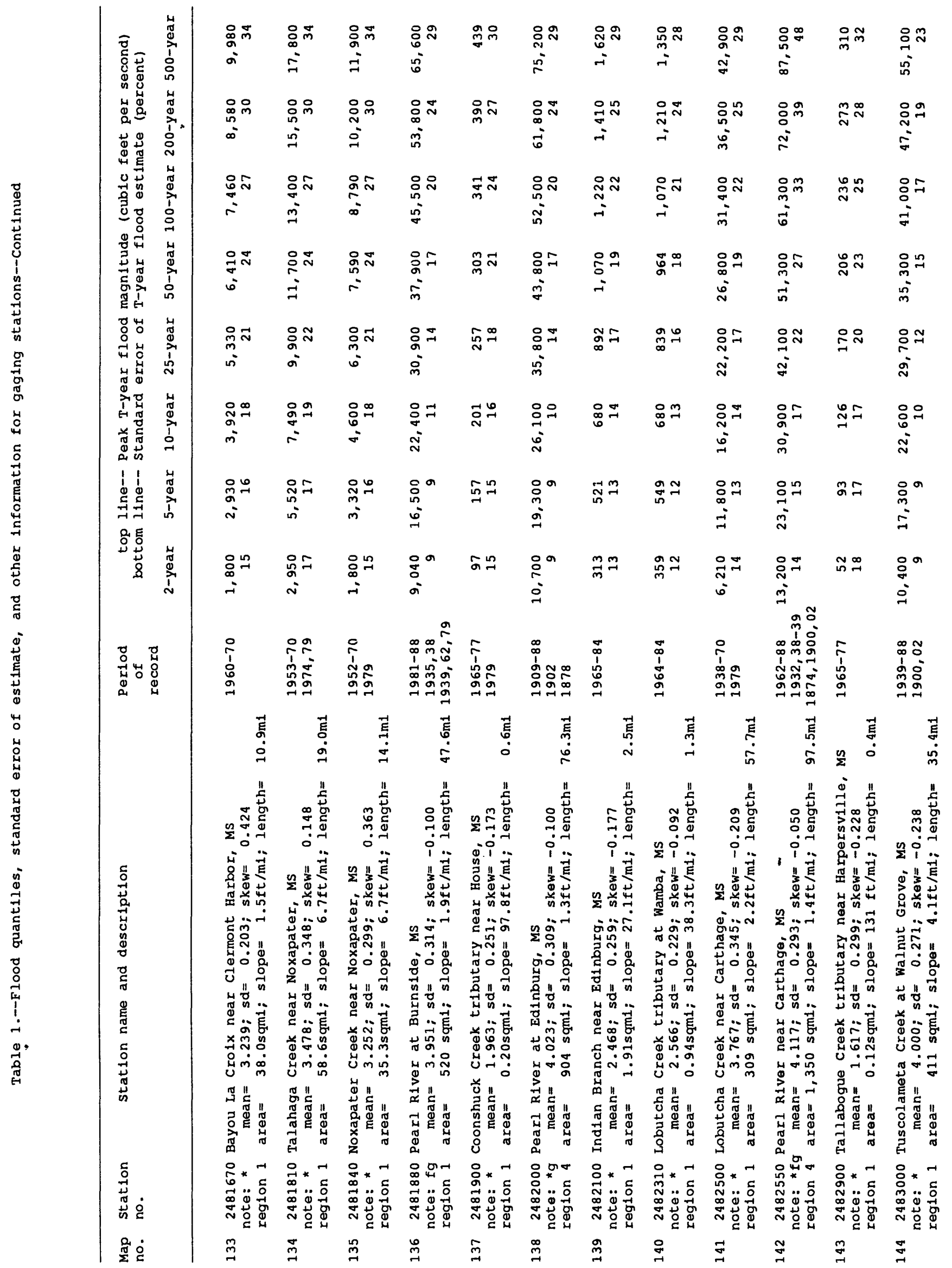




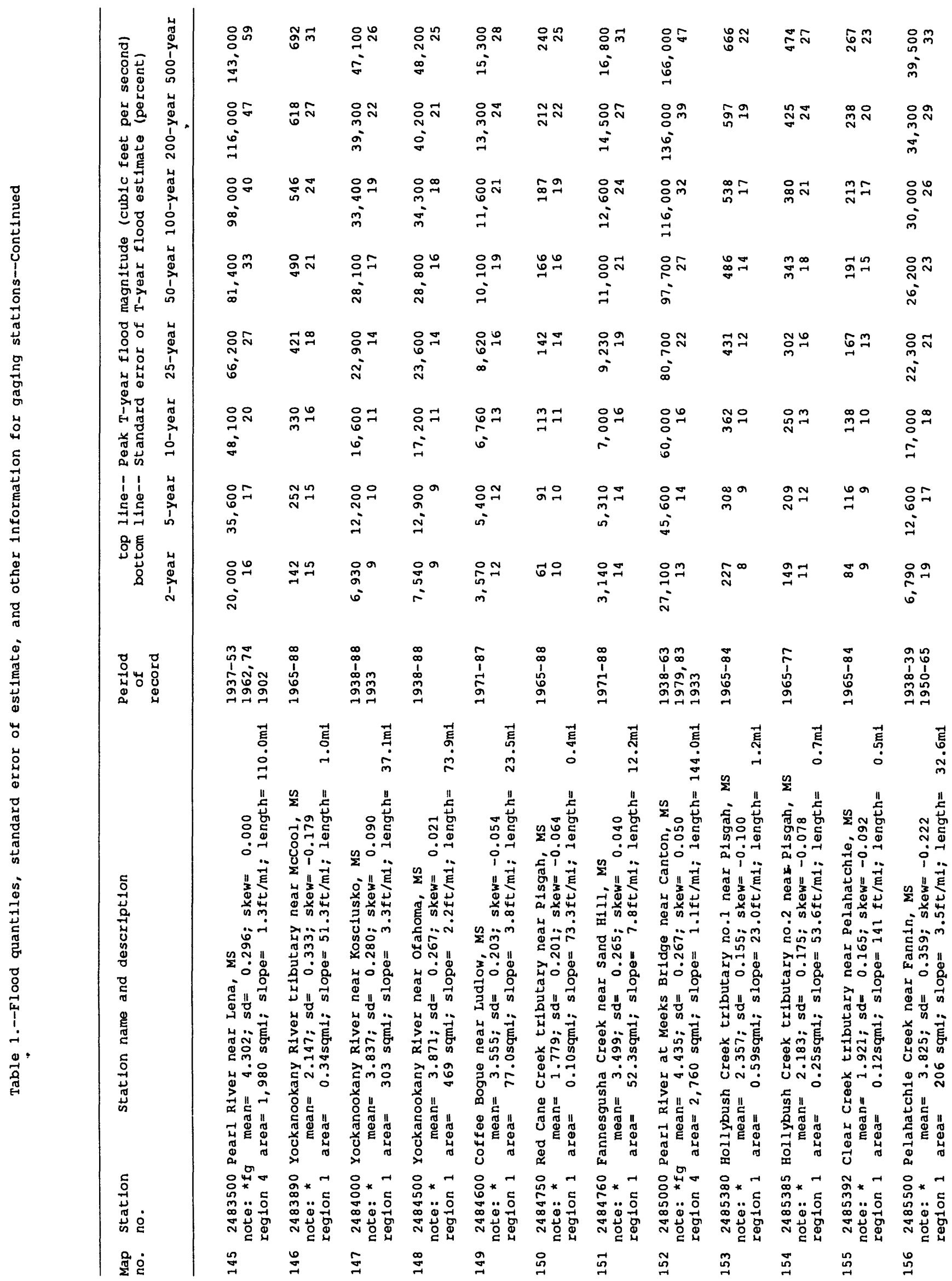




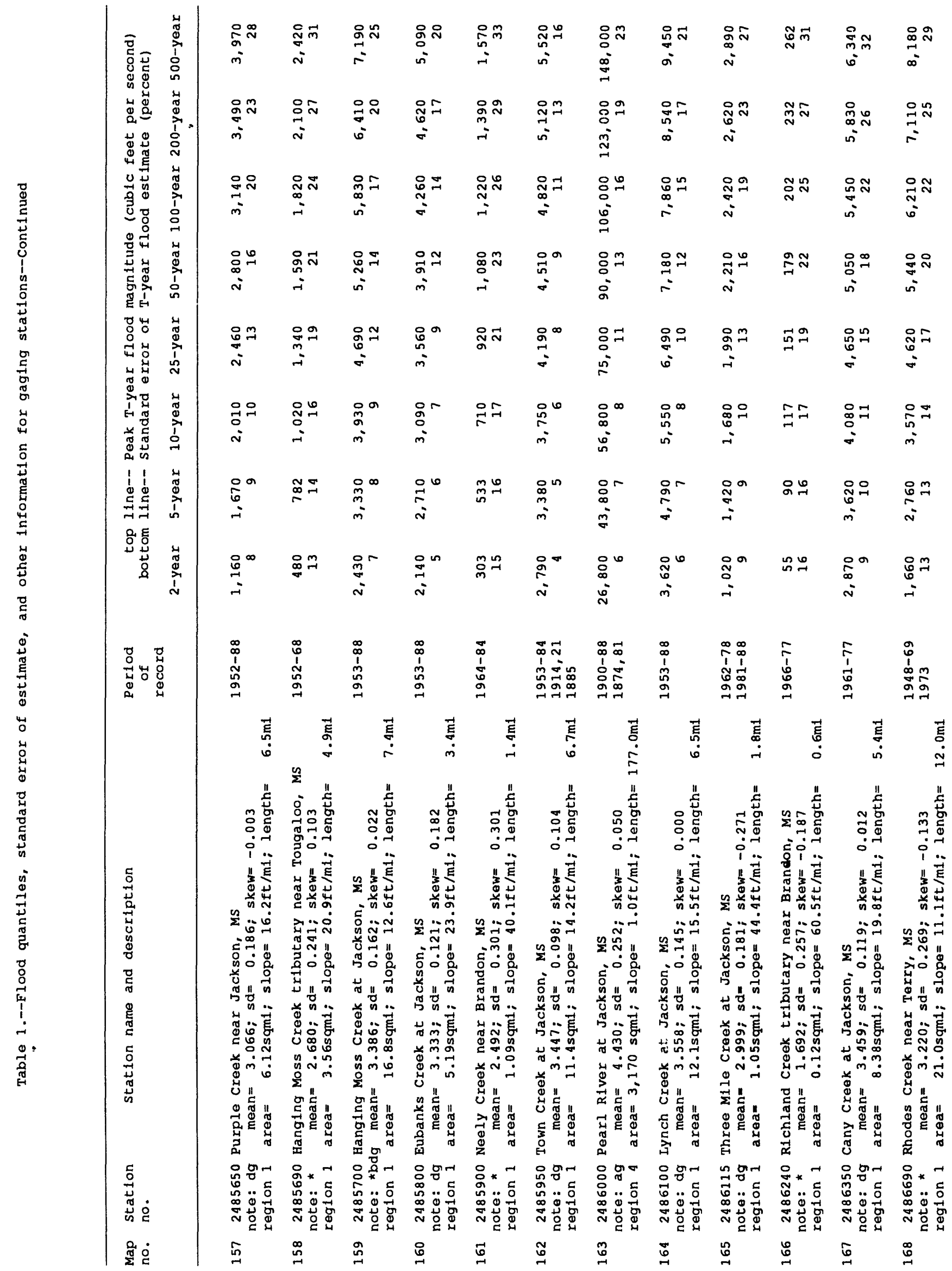




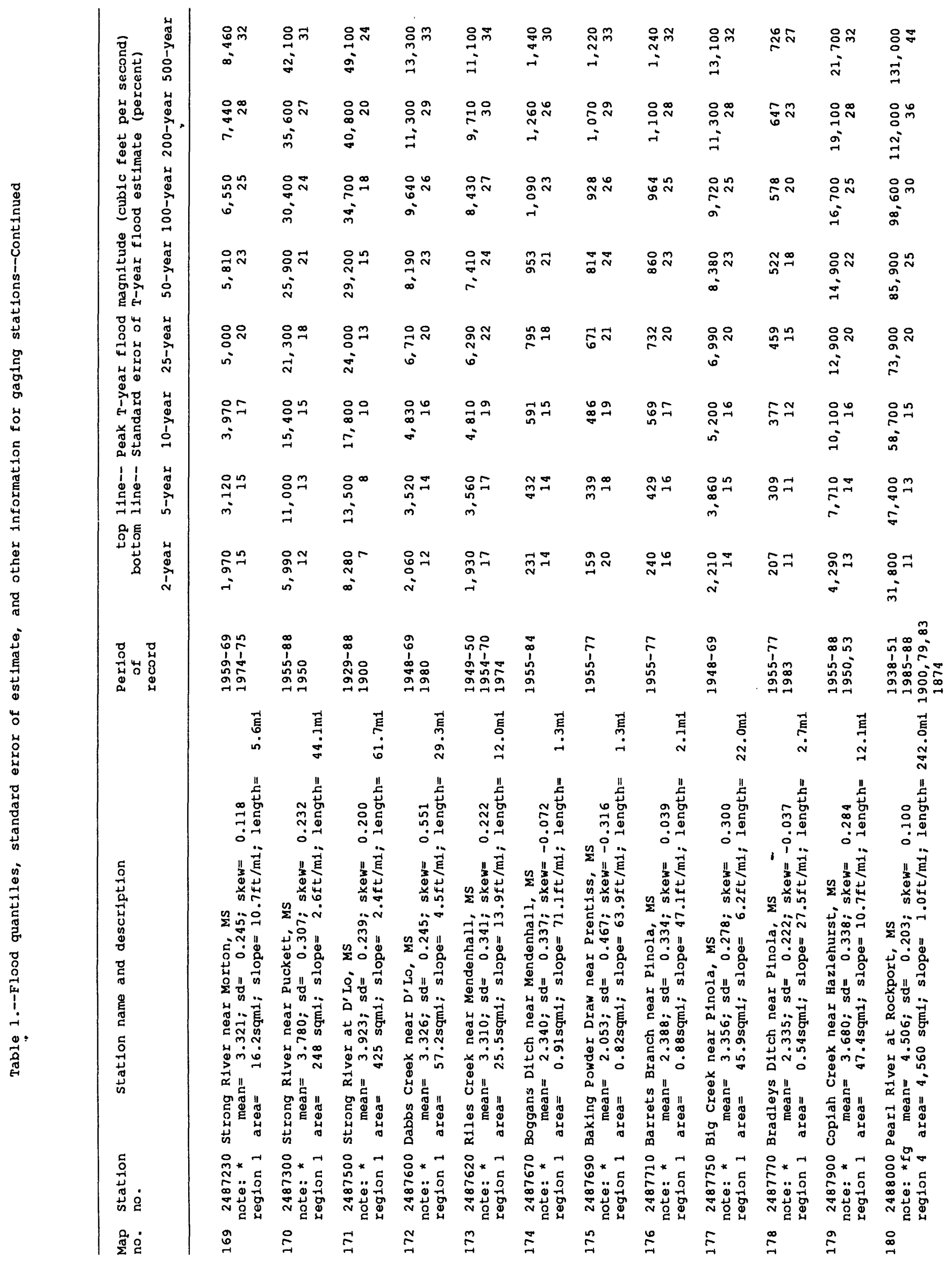




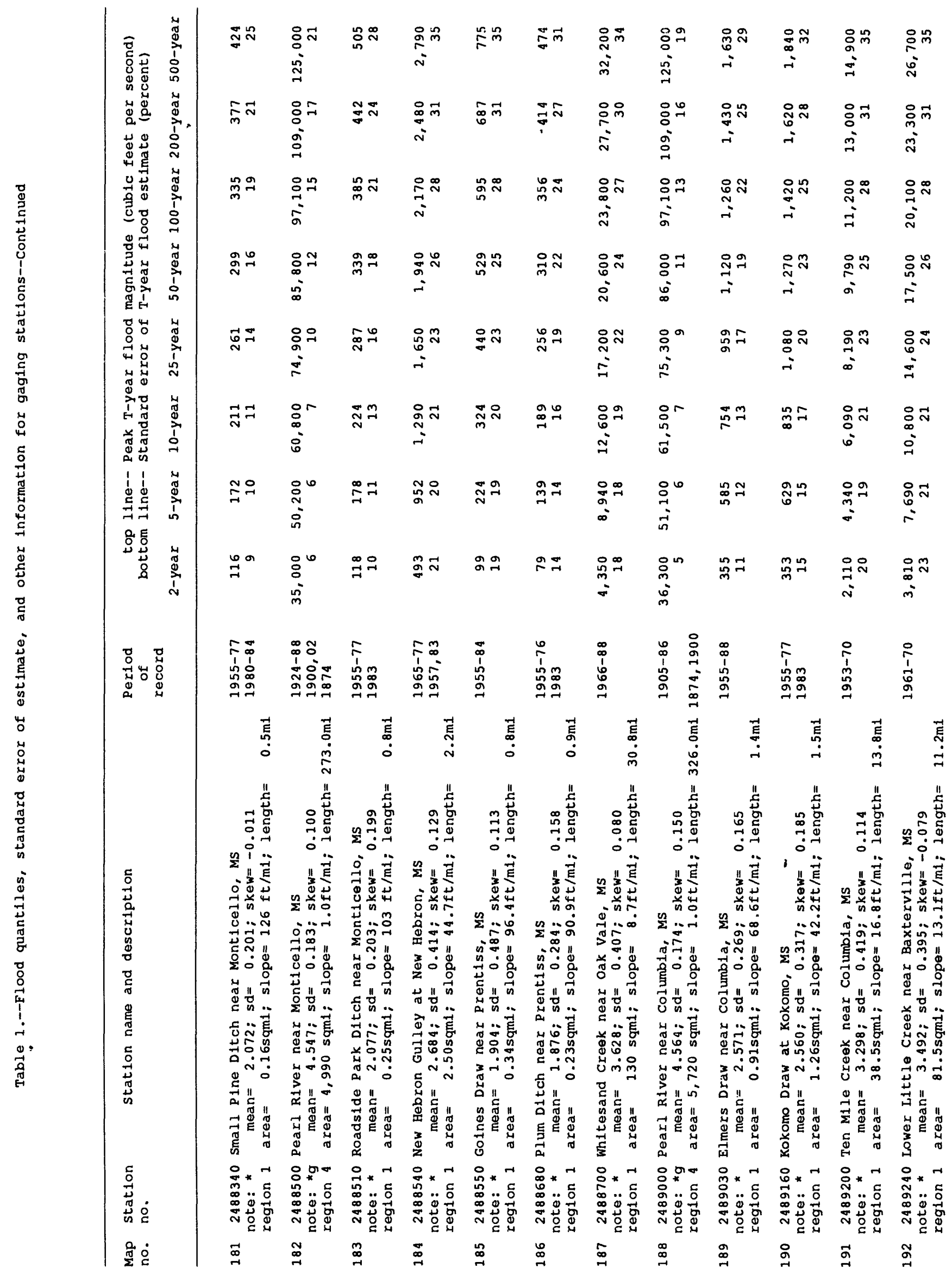




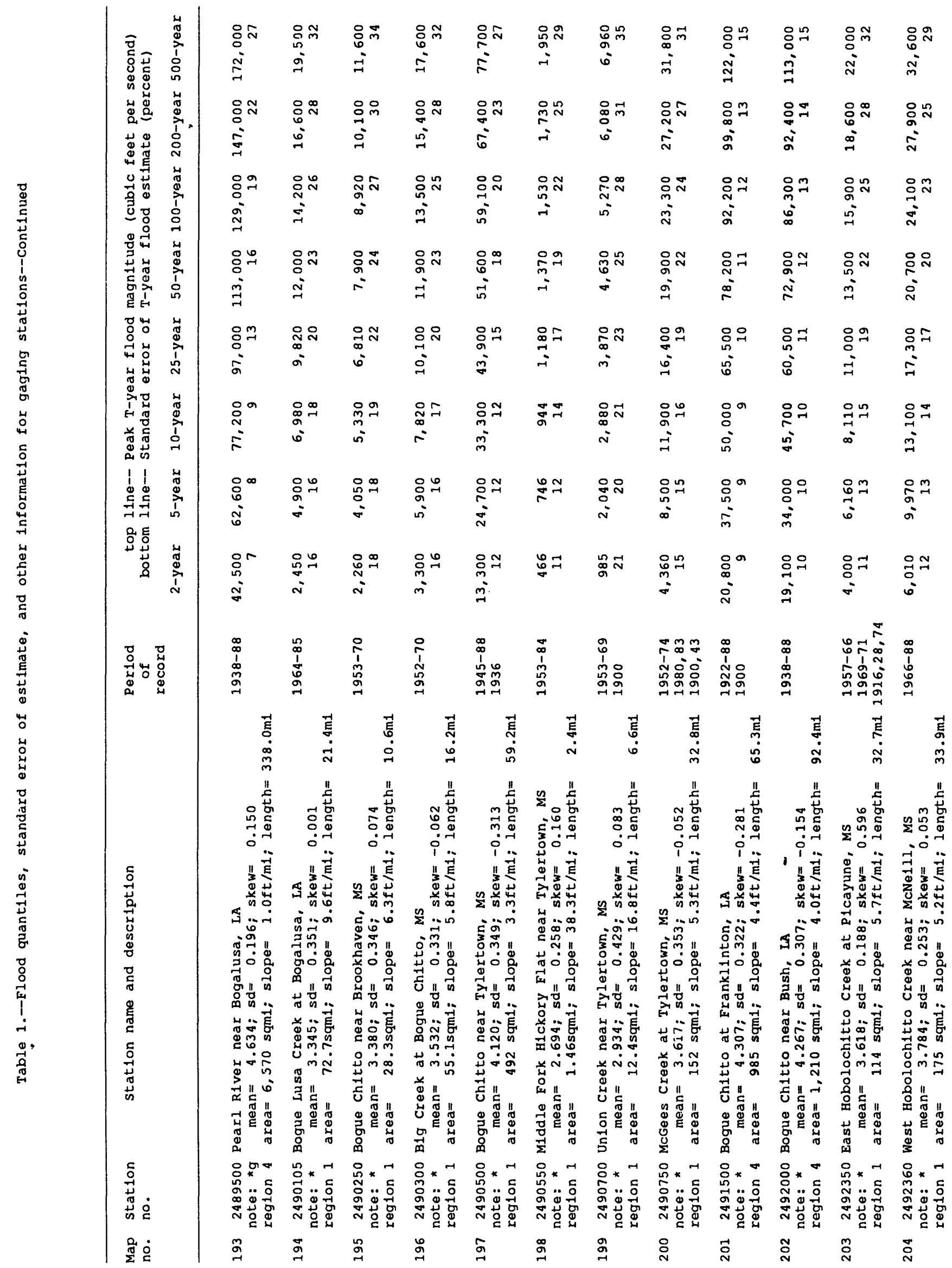




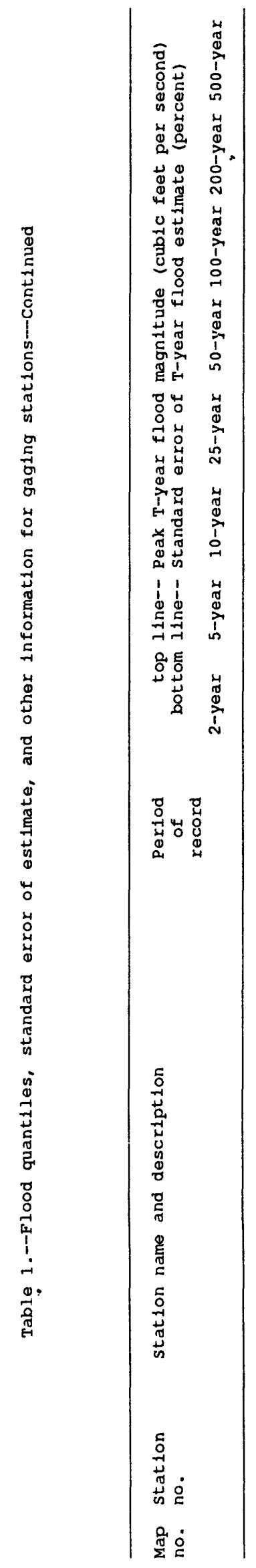

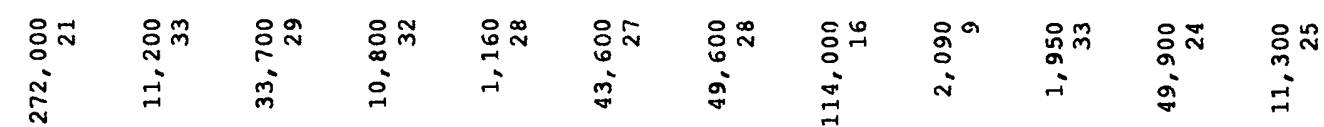

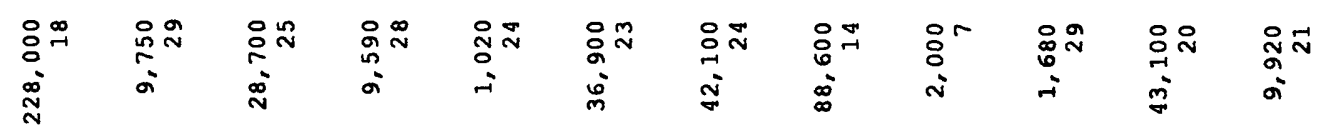

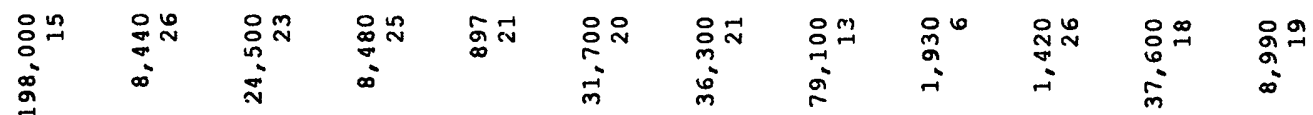

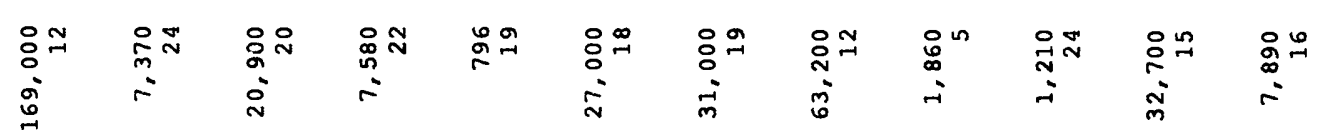

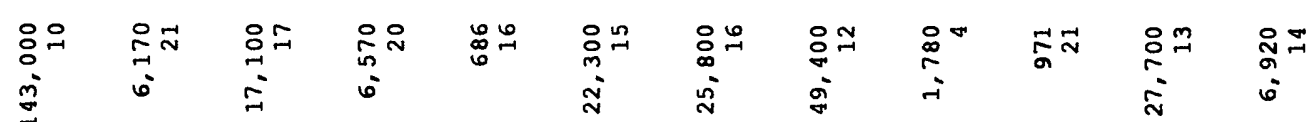

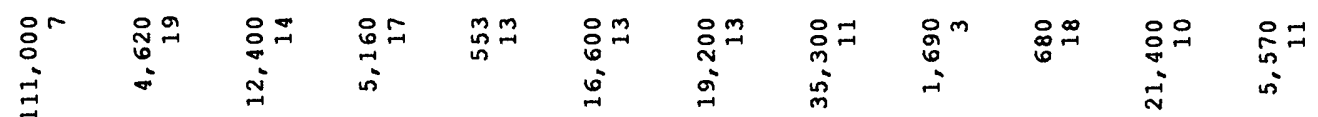

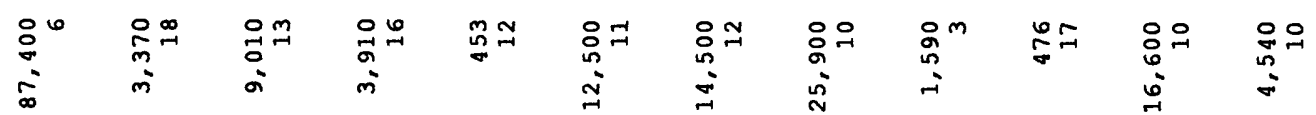

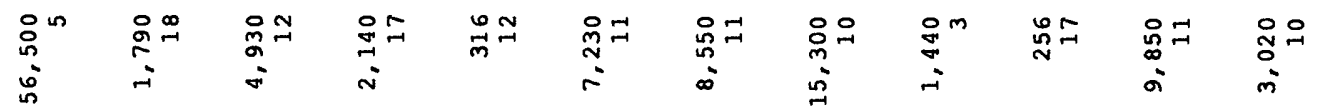

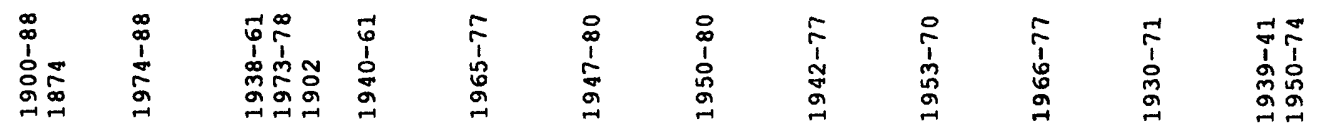

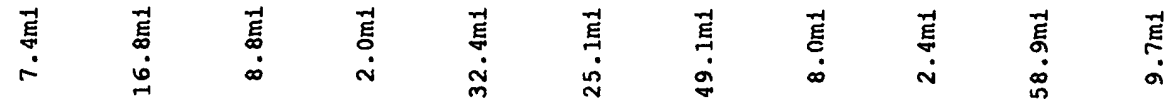

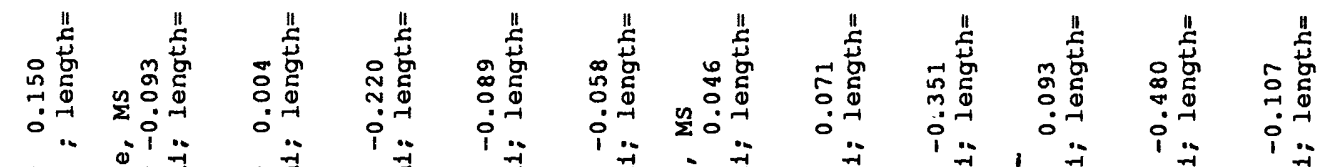

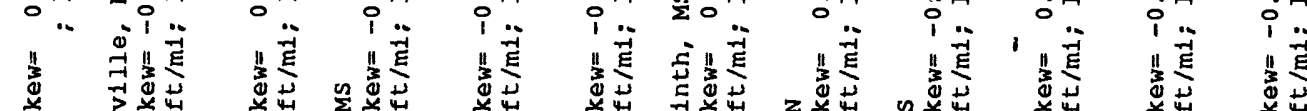

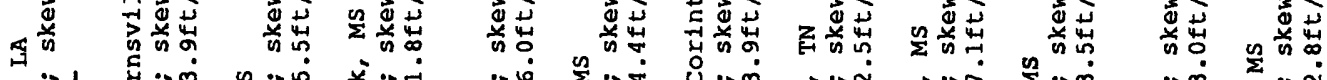

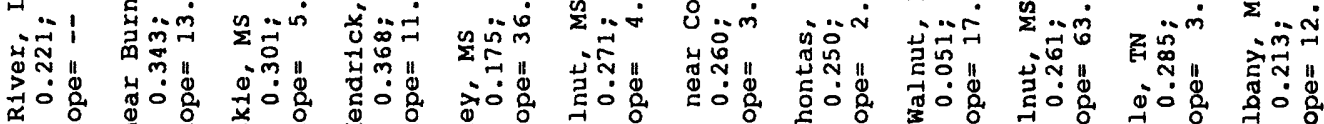

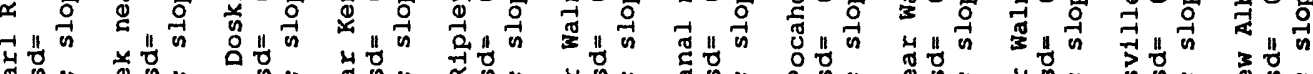

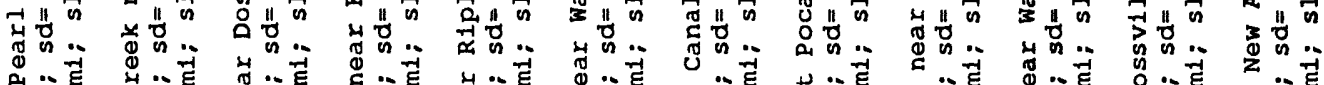

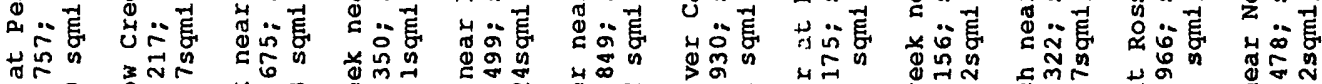

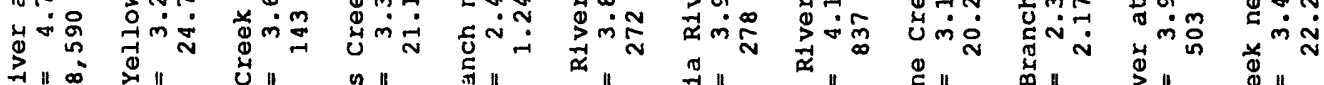

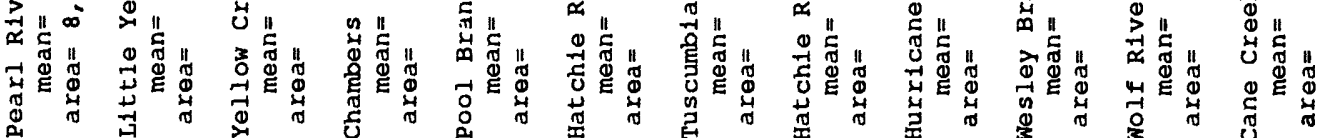
ब

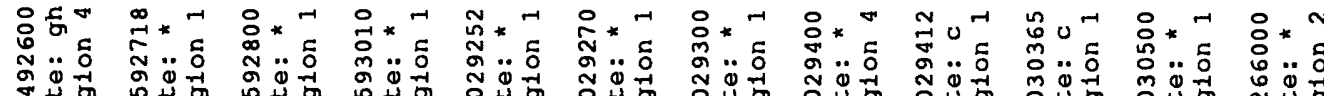

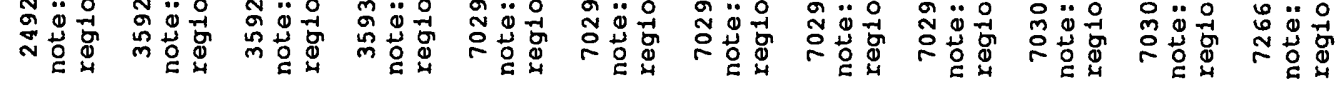

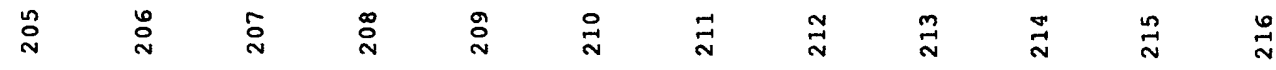




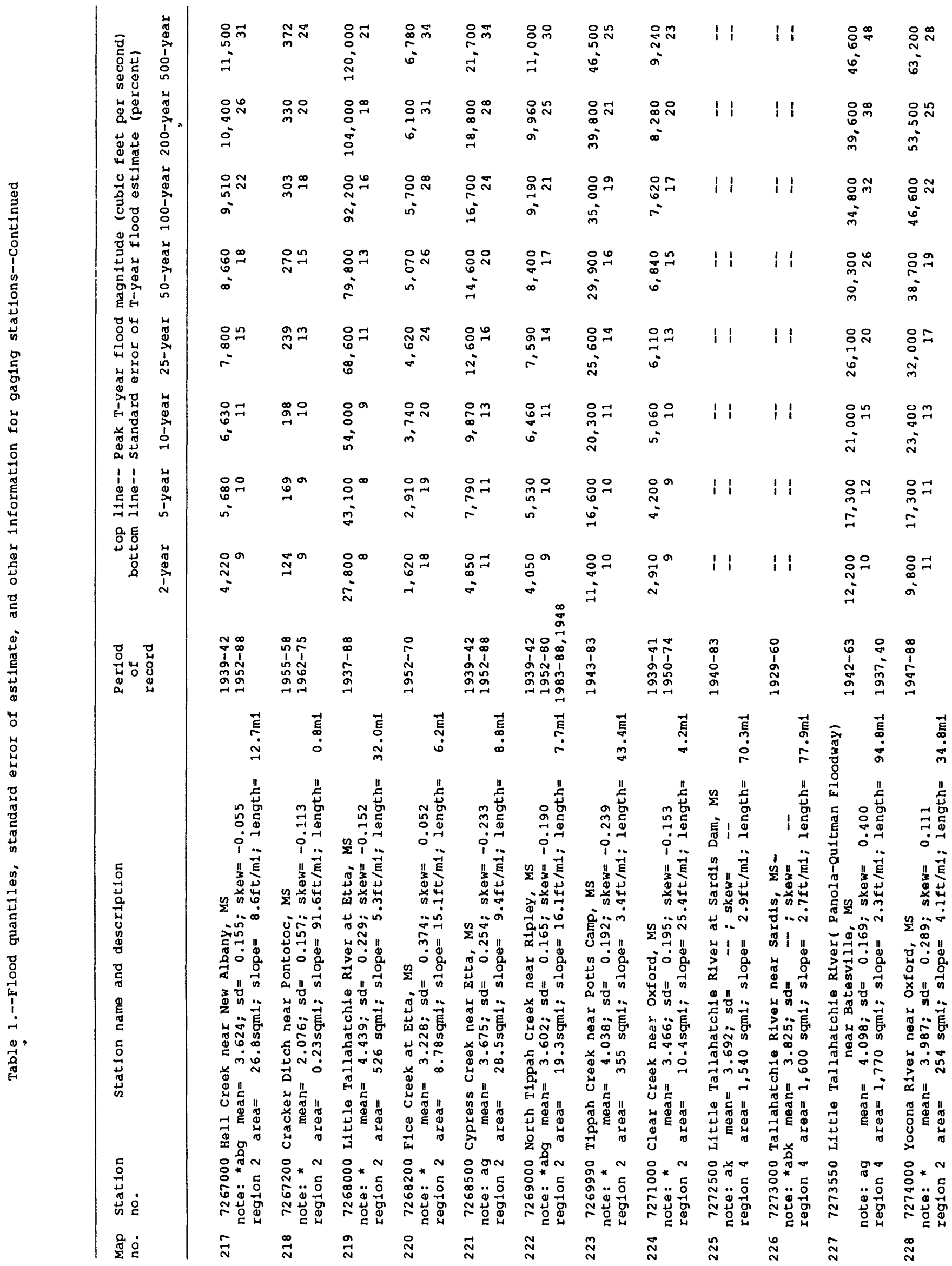




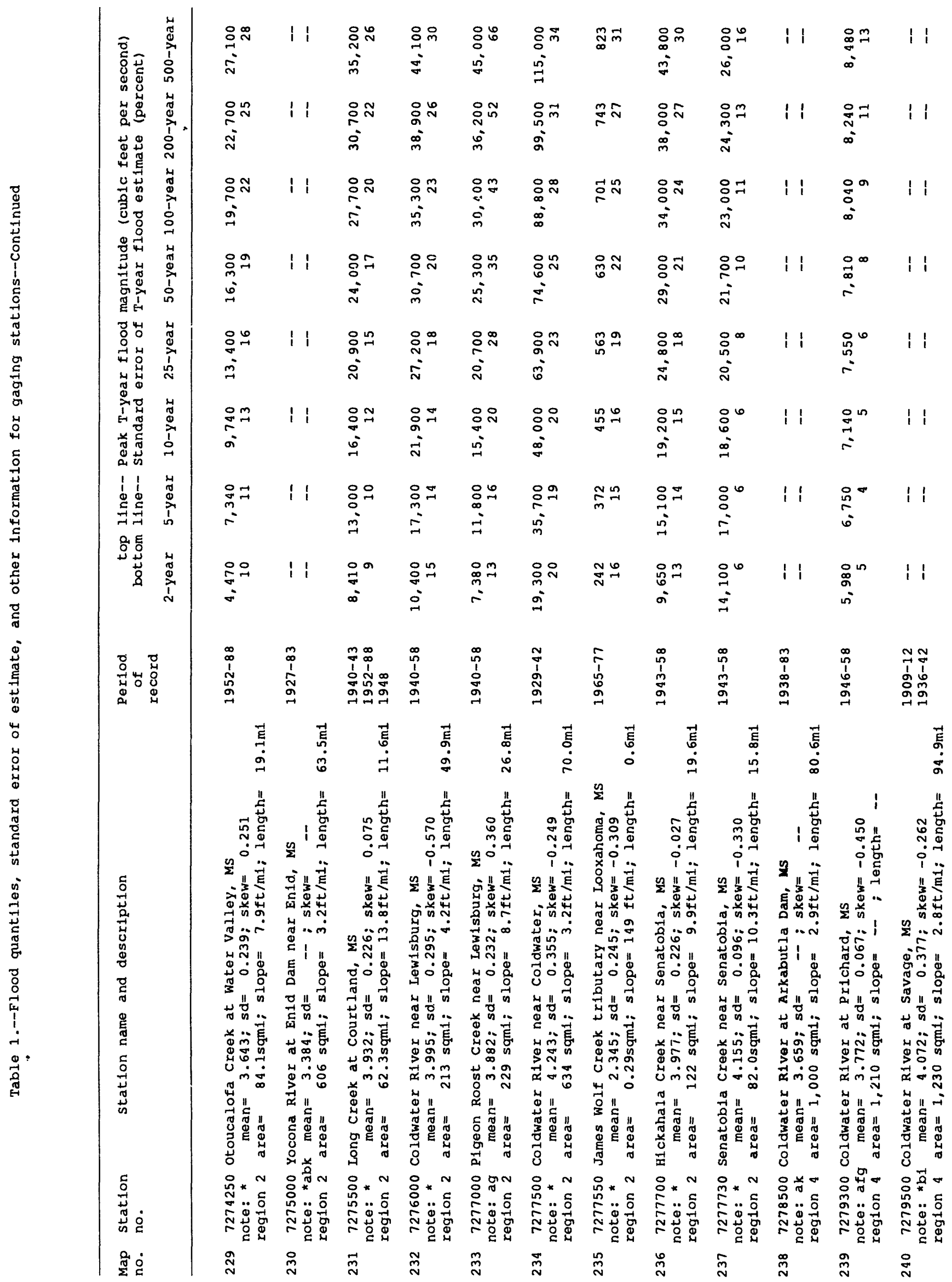




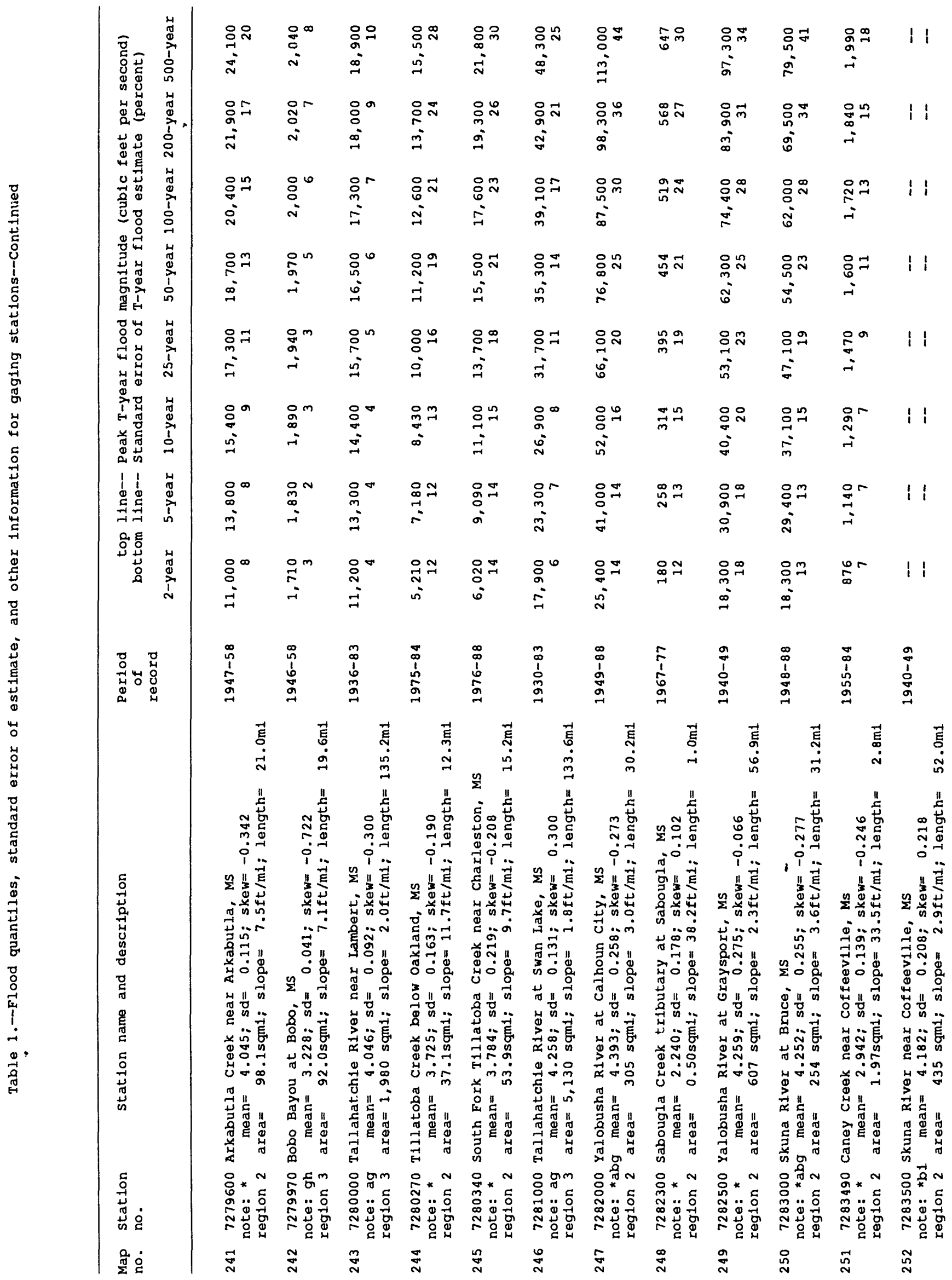




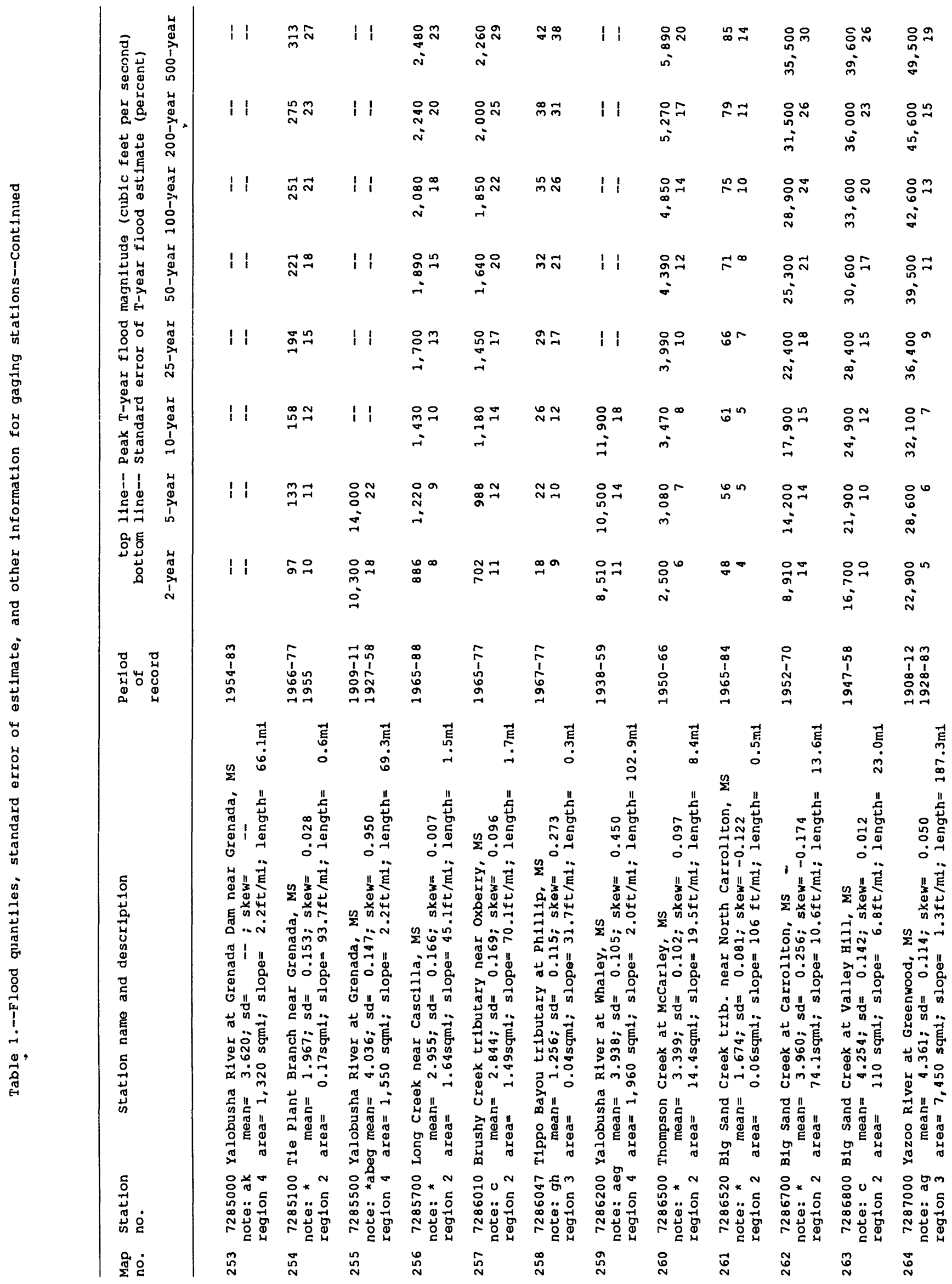




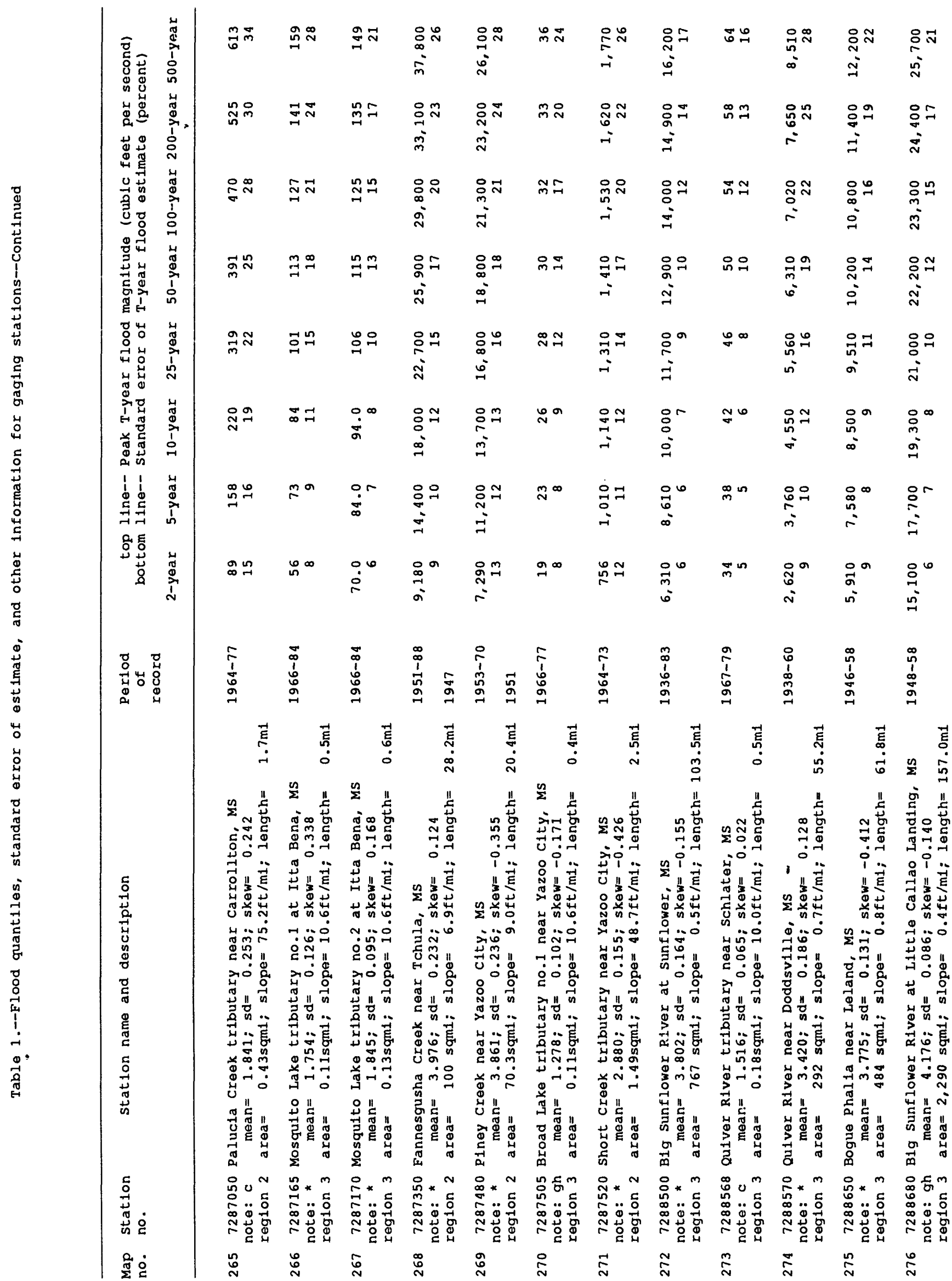




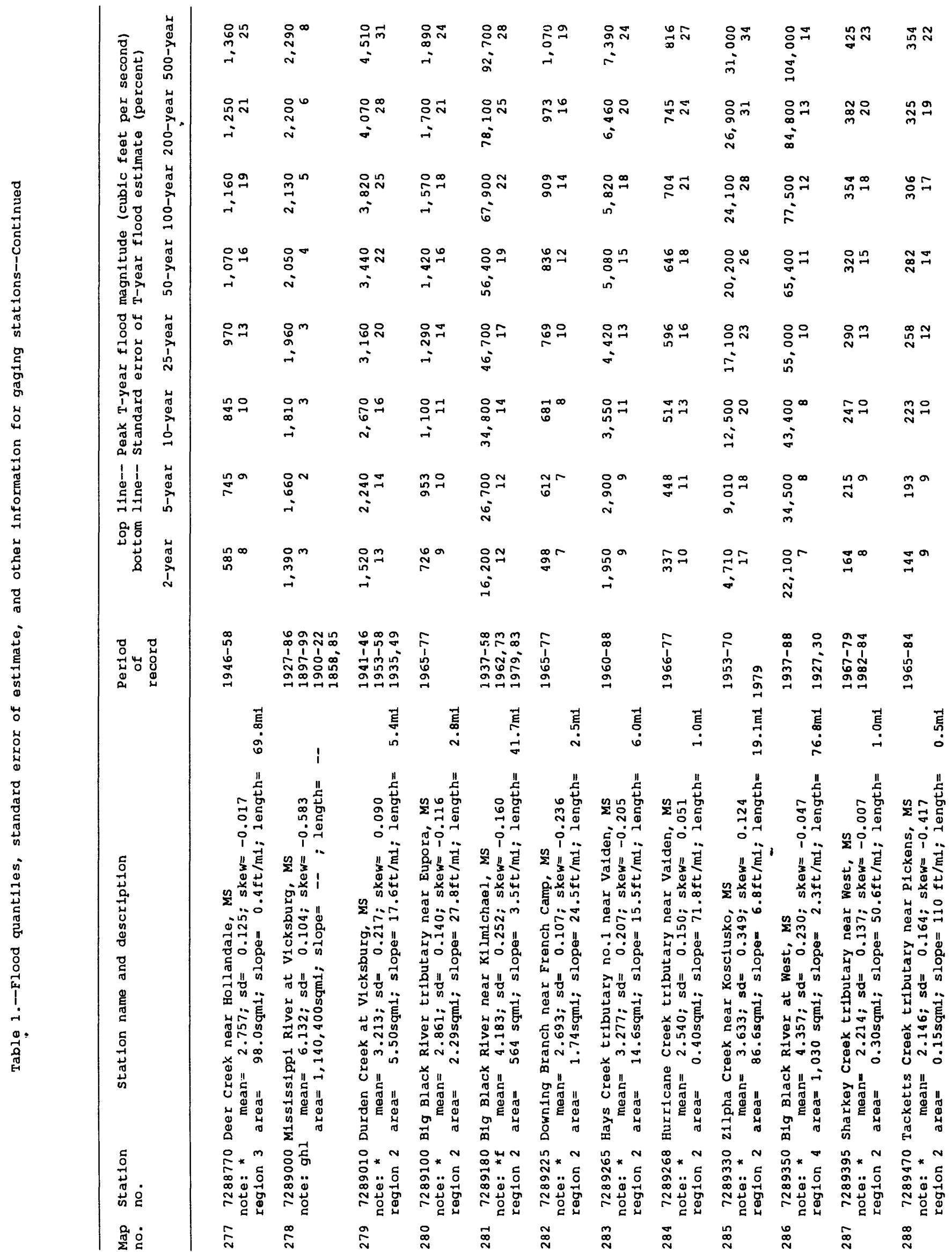




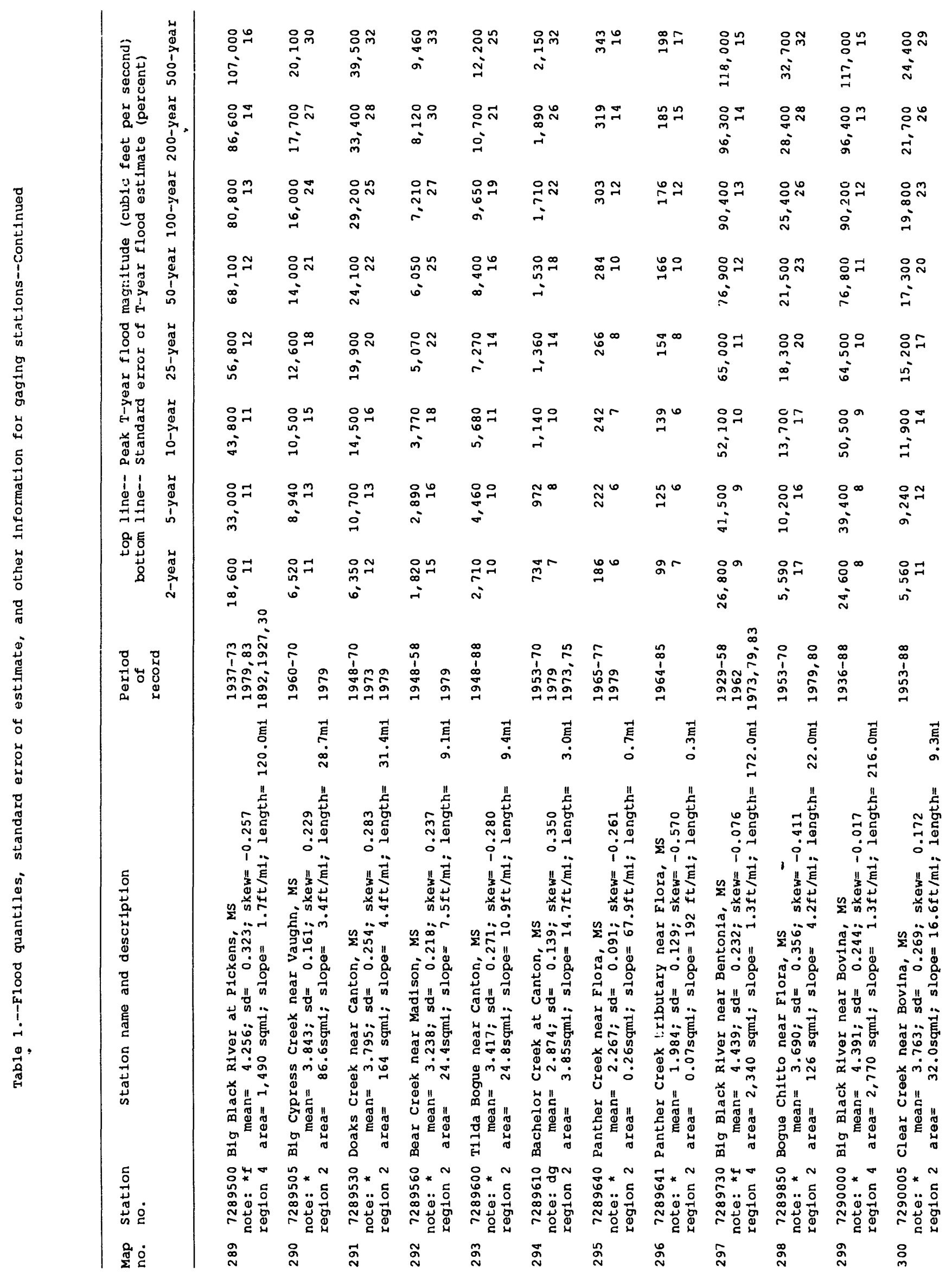




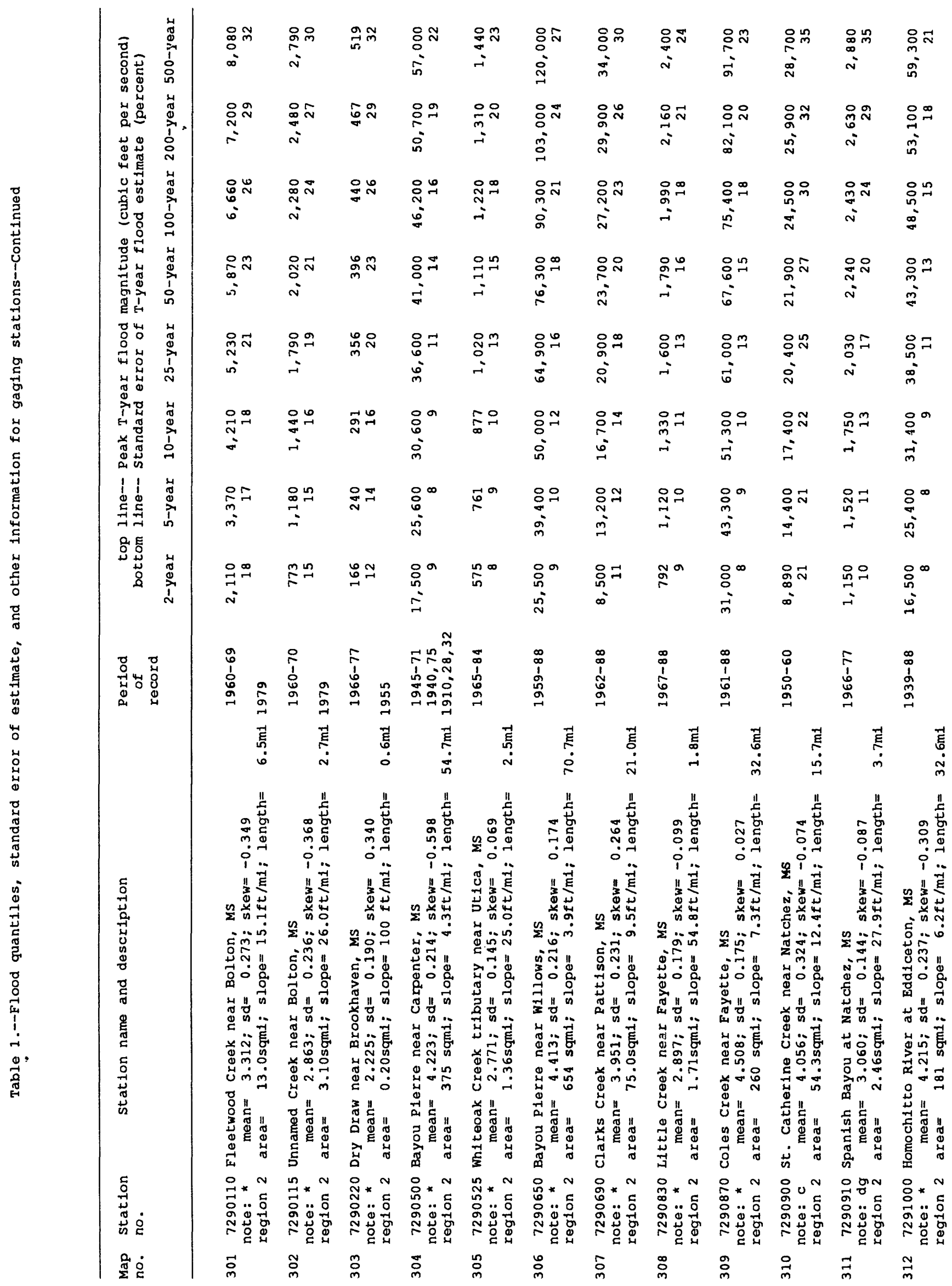




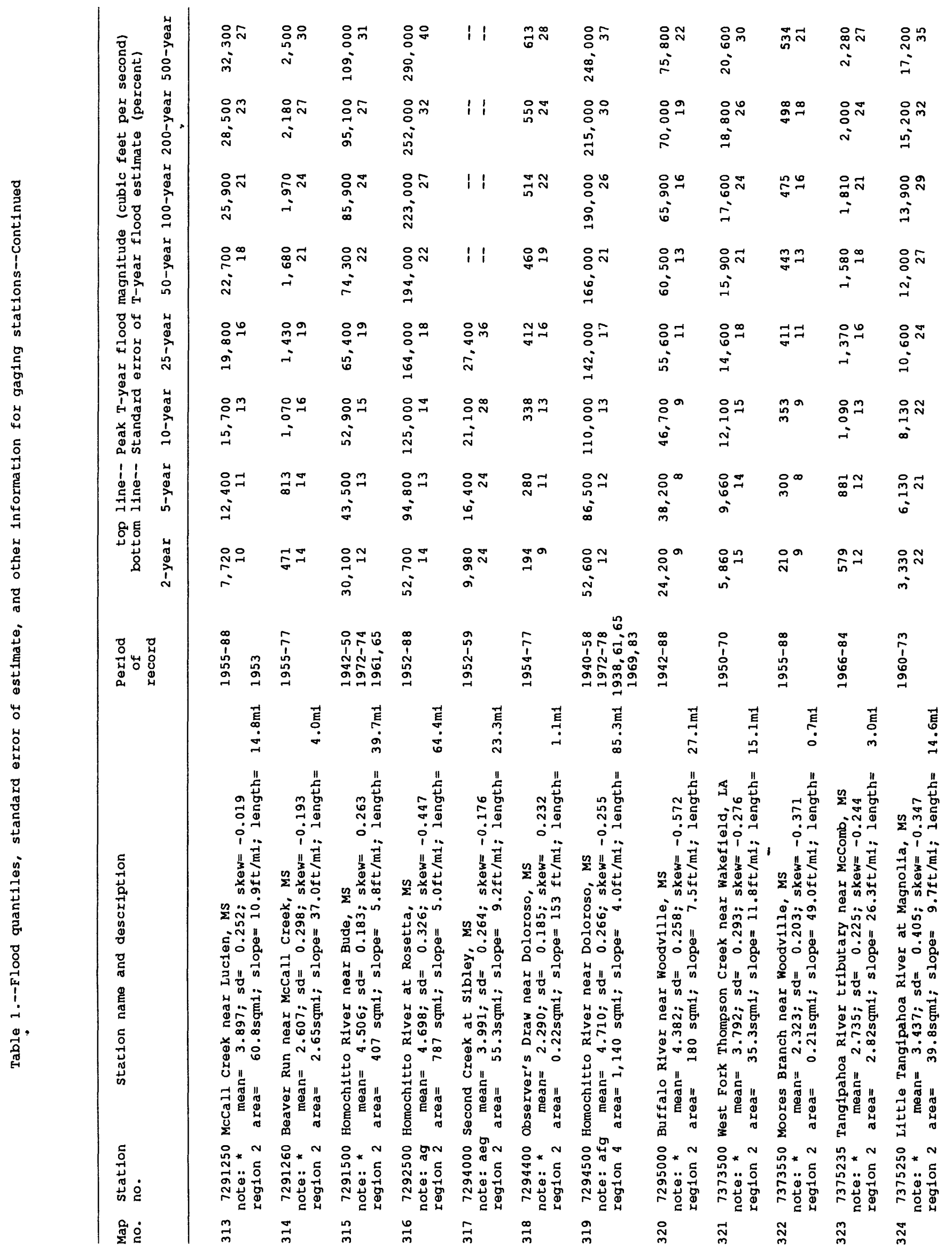




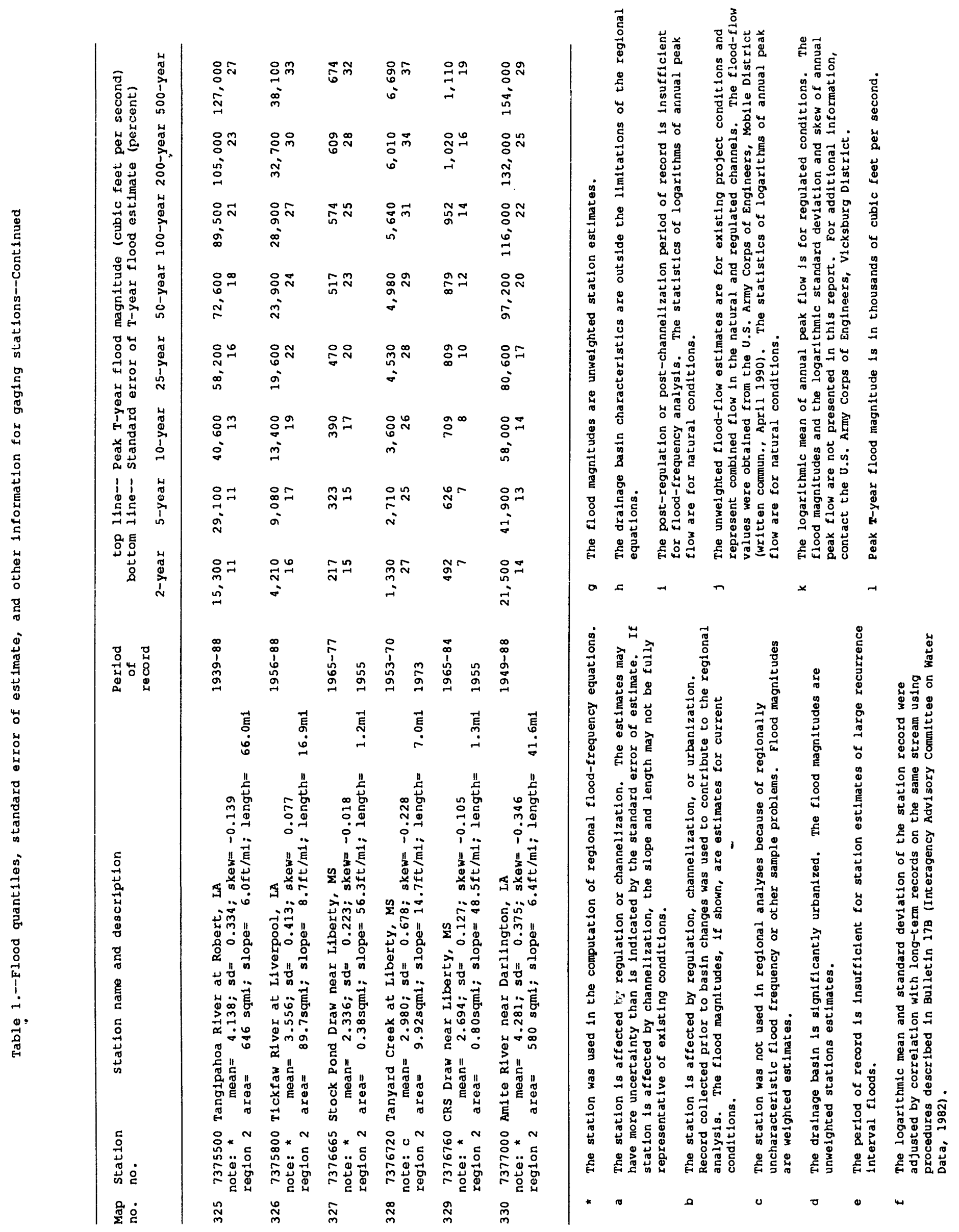




\section{APPENDIX}

REGIONAL SKEW COEFFICIENTS 


\section{REGIONAL SKEW COEFFICIENTS}

Regional skew coefficients are typically estimated from the sample skews of long-term annual peak-flow record stations in the study area using regression, mapping, or simple averaging methods. The IACWD (1982) provides a skew contour map of the United States for regional skew estimates; however, due to its limited accuracy and subsequent improvements in estimating methods, the Committee suggests that separate regional skew analyses be made. Ordinary mean, contour mapping, and leastsquares methods assume that the sampling distribution has uniform sampling variance; that is, skew coefficients computed from log-transformed annual peak-flow records of different gaging stations are all assumed to have equal accuracy. However, previous studies have shown the sample variance of skew to vary with record length. Therefore, methods which include a weighting function to account for nonuniform sampling variance estimate regional skew with greater accuracy. Tasker and Stedinger (1986) used weighted-least-squares procedures to estimate regional skew coefficients and showed improved results over ordinary least-squares procedures. The weighted-mapping procedure used in this report positions contour lines according to weighted grid-node values.

\section{Skew Weighting Functions}

The sampling variance $\left(V_{S}\right)$ of skew varies with the length of record $(N)$ and must be estimated to define a weighting function. Because the exact form of the probability distribution of sample skew $\left(G_{S}\right)$ is unknown, estimates of the sampling variance require either an assumed distribution for $\mathbf{G}_{\boldsymbol{S}}$ or a nonparametric approach. Sampling variances of $\mathbf{G}_{\mathbf{S}}$ assuming a log-Pearson distribution and based on Monte Carlo experiments may be obtained from Wallis and others (1974). Where a normal distribution is assumed for $\mathbf{G}_{\mathbf{S}}$, several parametric equations have been used to estimate the sample variance of skew coefficients. This investigation uses the parametric method of Fisher (1931) and Tasker and Stedinger (1986), corrected for bias and defined as:

$$
V_{S}=\frac{6 N(N-1)[1+(6 / N)]^{2}}{(N-2)(N+1)(N+3)}
$$


Comparisons of skew sample variance estimating methods by Tung and Mays (1981) indicate nonparametric approaches provide greater accuracy than parametric ones; however, the improvements shown over Fisher's method did not warrant the greater computational requirements of nonparametric procedures in this investigation. Sample skew is weighted inversely proportional to its estimated sample variance, so the weighting function is defined by:

$$
\mathrm{W}=1 / \mathrm{V}_{\mathrm{S}}
$$

where $W$ is the weight given to $G_{\mathbf{S}}$.

This weighting function was applied to mapping methods used to estimate regional skew coefficients.

\section{Weighted Mapping of Skew}

The spatial variability of skew suggests description by regionalization and contour mapping. Automatic mapping techniques have been developed to eliminate the subjectivity of hand-drawn contour maps. Automatic mapping generally requires initially gridding the study area. Gridding consists of estimating the value of the study variable at each node of a regular grid over the study area. Contour lines are then drawn based on the grid node values by a cubic spline or similar fitting process. Grid node values may be estimated by a two-step procedure. First, a spatial search is made to select the subset of sample data points to be used in estimating each node. Various search procedures may be used, the simplest being to select the nearest data points for each grid node. Second, the grid node estimate is computed from the selected data point values by a distance-weighted mean, where the weights are a function of distance from the grid node and uniform sampling variance is assumed. Nonuniform variance of sample data point values may be accounted for by using a weighting function in the grid node estimator. In 
this analysis, grid node estimates were weighted for error of sample skew and for sample point distance from the grid node by the following equation:

$$
Z_{i}=\frac{\sum_{j=1}^{n_{i}} G_{s_{j}}\left(W_{j}\right)\left(1 / d_{j}\right)}{\sum_{j=1}^{n_{i}}\left(W_{j}\right)\left(1 / d_{j}\right)}
$$

where

$\mathbf{Z}_{\mathbf{i}}$ is the estimated skew at grid node $\mathbf{i} ;$

$\mathrm{G}_{\mathbf{S}}$ is the unbiased skew of station $\mathbf{j}$;

n is the number of sample points selected to estimate $\mathbf{Z}_{\mathbf{i}}$;

$\mathbf{d}_{\mathbf{j}}$ is the distance from the grid node to the centroid of the basin whose records define $\mathrm{G}_{\mathbf{s}_{j}}$; and

$W_{j}$ is the weight given to $G_{\mathbf{S}}$ at station $\mathbf{j}$, as determined from equation 48 .

Weighting for sampling error increases the accuracy of the contour map by eliminating the assumption of uniform sampling error. This weighted mapping method assumes sample skews to be independent. Weighted-grid map methods are used to estimate regional skew coefficients for Mississippi streams.

Regional skew coefficients for flood-frequency analysis of Mississippi streams were determined using sample skews from 171 long-term streamflow-gaging stations (table 6). The sample skews were computed by equation 3 and corrected for bias using equation 4 from systematic-record periods through 1986. The systematic-record periods for the skew data average more than 30 years, and there are more than 10 years for every gaging station. Skew characteristics were tested for heterogeneity between distinct regions, and particularly, between large basins. The boxplots and boundaries of the three homogeneous skew coefficient regions are shown in figure 14. 
Table 6. - Gaging stations used in skew coefficlent analysis

\begin{tabular}{|c|c|c|c|c|c|c|c|c|}
\hline $\begin{array}{l}\text { Station } \\
\text { Number }\end{array}$ & $\begin{array}{l}\text { Reg- } \\
\text { lon }\end{array}$ & $\begin{array}{c}\text { Unbiased } \\
\text { Skew }\end{array}$ & $\begin{array}{c}\text { Station } \\
\text { Number }\end{array}$ & $\begin{array}{l}\text { Reg- } \\
\text { ion }\end{array}$ & $\begin{array}{c}\text { Unbiased } \\
\text { Skew }\end{array}$ & $\begin{array}{c}\text { Station } \\
\text { Number }\end{array}$ & $\begin{array}{l}\text { Reg- } \\
\text { ion }\end{array}$ & $\begin{array}{c}\text { Unbiased } \\
\text { Skew }\end{array}$ \\
\hline $\begin{array}{l}2430000 \\
2430500 \\
2431000 \\
2432900 \\
2433000\end{array}$ & $\begin{array}{l}\text { S3 } \\
\text { S3 } \\
\text { S3 } \\
\text { S3 } \\
\text { S3 }\end{array}$ & $\begin{array}{r}0.166 \\
0.534 \\
-0.134 \\
0.271 \\
0.014\end{array}$ & $\begin{array}{l}2479000 \\
2479165 \\
2479180 \\
2479190 \\
2479300\end{array}$ & $\begin{array}{l}S 1 \\
S 1 \\
S 1 \\
S 1 \\
S 1\end{array}$ & $\begin{array}{l}0.253 \\
0.135 \\
0.204 \\
0.530 \\
0.658\end{array}$ & $\begin{array}{l}7077920 \\
7077940 \\
7077950 \\
7078000 \\
7078170\end{array}$ & $\begin{array}{l}\text { S2 } \\
\text { S2 } \\
\text { S2 } \\
\text { S2 } \\
\text { S2 }\end{array}$ & $\begin{array}{l}-0.959 \\
-1.366 \\
-1.424 \\
-0.750 \\
-1.841\end{array}$ \\
\hline $\begin{array}{l}2433500 \\
2434000 \\
2434500 \\
2435300 \\
2435400\end{array}$ & $\begin{array}{l}\text { S3 } \\
\text { S3 } \\
\text { S3 } \\
\text { S3 } \\
\text { S3 }\end{array}$ & $\begin{array}{l}0.080 \\
0.202 \\
0.040 \\
0.547 \\
0.165\end{array}$ & $\begin{array}{l}2479500 \\
2480150 \\
2480500 \\
2481130 \\
2481400\end{array}$ & $\begin{array}{l}S 1 \\
S 1 \\
S 1 \\
S 1 \\
S 1\end{array}$ & $\begin{array}{r}0.708 \\
-0.246 \\
0.826 \\
0.826 \\
1.273\end{array}$ & $\begin{array}{l}7263860 \\
7264000 \\
7264100 \\
7266000 \\
7268000\end{array}$ & $\begin{array}{l}\text { S2 } \\
\text { S2 } \\
\text { S2 } \\
\text { S3 } \\
\text { S3 }\end{array}$ & $\begin{array}{r}-1.523 \\
0.092 \\
-1.233 \\
-0.298 \\
-0.250\end{array}$ \\
\hline $\begin{array}{l}2435500 \\
2435800 \\
2435920 \\
2435930 \\
2436500\end{array}$ & $\begin{array}{l}\text { S3 } \\
\text { S3 } \\
\text { S3 } \\
\text { S3 } \\
\text { S3 }\end{array}$ & $\begin{array}{r}0.390 \\
0.235 \\
-0.573 \\
0.991 \\
0.852\end{array}$ & $\begin{array}{l}2481450 \\
2482000 \\
2482100 \\
2482310 \\
2482500\end{array}$ & $\begin{array}{l}\text { S1 } \\
\text { S3 } \\
\text { S3 } \\
\text { S3 } \\
\text { S3 }\end{array}$ & $\begin{array}{r}1.732 \\
-0.429 \\
-0.367 \\
-0.105 \\
-0.340\end{array}$ & $\begin{array}{l}7269990 \\
7271000 \\
7275000 \\
7275500 \\
7282000\end{array}$ & $\begin{array}{l}\text { S3 } \\
\text { S3 } \\
\text { S3 } \\
\text { S3 } \\
\text { S3 }\end{array}$ & $\begin{array}{r}-0.398 \\
-0.250 \\
0.105 \\
0.033 \\
-0.614\end{array}$ \\
\hline $\begin{array}{l}2437000 \\
2437300 \\
2437500 \\
2437550 \\
2437600\end{array}$ & $\begin{array}{l}\text { S3 } \\
\text { S3 } \\
\text { S3 } \\
\text { S3 } \\
\text { S3 }\end{array}$ & $\begin{array}{r}0.355 \\
-0.023 \\
0.187 \\
0.038 \\
0.050\end{array}$ & $\begin{array}{l}2483890 \\
2484000 \\
2484500 \\
2484750 \\
2485380\end{array}$ & $\begin{array}{l}\text { S3 } \\
\text { S3 } \\
\text { S3 } \\
\text { S3 } \\
\text { S3 }\end{array}$ & $\begin{array}{r}-0.442 \\
0.113 \\
-0.003 \\
-0.136 \\
-0.234\end{array}$ & $\begin{array}{l}7283490 \\
7285700 \\
7286000 \\
7286047 \\
7286520\end{array}$ & $\begin{array}{l}\text { S3 } \\
\text { S3 } \\
\text { S2 } \\
\text { S2 } \\
\text { S3 }\end{array}$ & $\begin{array}{r}-0.511 \\
0.076 \\
-0.748 \\
0.757 \\
-0.198\end{array}$ \\
\hline $\begin{array}{l}2439800 \\
2439980 \\
2440400 \\
2440600 \\
2440800\end{array}$ & $\begin{array}{l}\text { S3 } \\
\text { S3 } \\
\text { S3 } \\
\text { S3 } \\
\text { S3 }\end{array}$ & $\begin{array}{r}-0.316 \\
0.753 \\
0.488 \\
0.459 \\
-0.396\end{array}$ & $\begin{array}{l}2485392 \\
2485900 \\
2486000 \\
2486690 \\
2487300\end{array}$ & $\begin{array}{l}\text { S3 } \\
\text { S3 } \\
\text { S3 } \\
\text { S3 } \\
\text { S3 }\end{array}$ & $\begin{array}{r}-0.300 \\
0.885 \\
-0.450 \\
-0.295 \\
0.362\end{array}$ & $\begin{array}{l}7287165 \\
7287170 \\
7287480 \\
7288500 \\
7288570\end{array}$ & $\begin{array}{l}\text { S2 } \\
\text { S2 } \\
\text { S3 } \\
\text { S2 } \\
\text { S2 }\end{array}$ & $\begin{array}{r}1.219 \\
0.590 \\
-0.648 \\
-0.138 \\
0.456\end{array}$ \\
\hline $\begin{array}{l}2441000 \\
2441220 \\
2441300 \\
2441500 \\
2443000\end{array}$ & $\begin{array}{l}\text { S3 } \\
\text { S3 } \\
\text { S3 } \\
\text { S3 } \\
\text { S3 }\end{array}$ & $\begin{array}{r}-0.926 \\
-0.455 \\
-0.246 \\
0.256 \\
0.099\end{array}$ & $\begin{array}{l}2487500 \\
2487620 \\
2487670 \\
2487710 \\
2487770\end{array}$ & $\begin{array}{l}\text { S3 } \\
\text { S3 } \\
\text { S3 } \\
\text { S3 } \\
\text { S3 }\end{array}$ & $\begin{array}{r}0.263 \\
0.459 \\
-0.242 \\
-0.006 \\
-0.145\end{array}$ & $\begin{array}{l}7288650 \\
7288770 \\
7289350 \\
7289530 \\
7289600\end{array}$ & $\begin{array}{l}\text { S2 } \\
\text { S2 } \\
\text { S3 } \\
\text { S3 } \\
\text { S3 }\end{array}$ & $\begin{array}{r}-1.067 \\
-1.083 \\
0.021 \\
0.835 \\
-0.508\end{array}$ \\
\hline $\begin{array}{l}2443700 \\
2444000 \\
2447500 \\
2447800 \\
2448000\end{array}$ & $\begin{array}{l}\text { S3 } \\
\text { S3 } \\
\text { S3 } \\
\text { S3 } \\
\text { S3 }\end{array}$ & $\begin{array}{r}0.046 \\
0.332 \\
-0.035 \\
0.332 \\
0.156\end{array}$ & $\begin{array}{l}2488340 \\
2488500 \\
2488510 \\
2488680 \\
2488700\end{array}$ & $\begin{array}{l}\text { S3 } \\
\text { S3 } \\
\text { S3 } \\
\text { S3 } \\
\text { S3 }\end{array}$ & $\begin{array}{r}-0.037 \\
0.105 \\
0.377 \\
0.342 \\
0.069\end{array}$ & $\begin{array}{l}7289641 \\
7290000 \\
7290005 \\
7290525 \\
7290650\end{array}$ & $\begin{array}{l}\text { S3 } \\
\text { S3 } \\
\text { S3 } \\
\text { S3 } \\
\text { S3 }\end{array}$ & $\begin{array}{r}-1.349 \\
0.056 \\
0.424 \\
0.289 \\
0.255\end{array}$ \\
\hline $\begin{array}{l}2467500 \\
2471100 \\
2471500 \\
2472000 \\
2472500\end{array}$ & $\begin{array}{l}\text { S3 } \\
\text { SI } \\
\text { SI } \\
\text { SI } \\
\text { S1 }\end{array}$ & $\begin{array}{r}0.702 \\
-0.166 \\
-0.103 \\
0.339 \\
0.829\end{array}$ & $\begin{array}{l}2489000 \\
2489030 \\
2489160 \\
2490000 \\
2490105\end{array}$ & $\begin{array}{l}\text { S3 } \\
\text { S3 } \\
\text { S3 } \\
\text { S3 } \\
\text { S3 }\end{array}$ & $\begin{array}{r}0.404 \\
0.235 \\
0.339 \\
-0.816 \\
0.154\end{array}$ & $\begin{array}{l}7290690 \\
7290870 \\
7291000 \\
7291250 \\
7291260\end{array}$ & $\begin{array}{l}\text { S3 } \\
\text { S3 } \\
\text { S3 } \\
\text { S3 } \\
\text { S3 }\end{array}$ & $\begin{array}{r}-0.045 \\
-0.393 \\
-0.634 \\
0.498 \\
-0.337\end{array}$ \\
\hline $\begin{array}{l}2473000 \\
2473480 \\
2473500 \\
2473850 \\
2474500\end{array}$ & $\begin{array}{l}S 1 \\
S 1 \\
S 1 \\
S 1 \\
S 1\end{array}$ & $\begin{array}{r}0.502 \\
-0.084 \\
-0.198 \\
-0.640 \\
0.405\end{array}$ & $\begin{array}{l}2490500 \\
2490550 \\
2491500 \\
2492360 \\
3592800\end{array}$ & $\begin{array}{l}\text { S3 } \\
\text { S3 } \\
\text { S3 } \\
\text { S3 } \\
\text { S3 }\end{array}$ & $\begin{array}{r}-0.515 \\
0.425 \\
-0.399 \\
-0.027 \\
0.001\end{array}$ & $\begin{array}{l}7294400 \\
7295000 \\
7364120 \\
7364150 \\
7364190\end{array}$ & $\begin{array}{l}\text { S3 } \\
\text { S3 } \\
\text { S2 } \\
\text { S2 } \\
\text { S2 }\end{array}$ & $\begin{array}{r}0.713 \\
-0.990 \\
-0.771 \\
-0.597 \\
-0.170\end{array}$ \\
\hline $\begin{array}{l}2474740 \\
2475000 \\
2475050 \\
2475220 \\
2475500\end{array}$ & $\begin{array}{l}\text { S1 } \\
\text { S1 } \\
S 1 \\
S 1 \\
S 1\end{array}$ & $\begin{array}{r}0.699 \\
0.384 \\
-0.007 \\
0.602 \\
0.105\end{array}$ & $\begin{array}{l}3593010 \\
7029270 \\
7029300 \\
7029400 \\
7030500\end{array}$ & $\begin{array}{l}\text { S3 } \\
\text { S3 } \\
\text { S3 } \\
\text { S3 } \\
\text { S3 }\end{array}$ & $\begin{array}{r}-0.481 \\
0.111 \\
0.109 \\
0.138 \\
-0.730\end{array}$ & $\begin{array}{l}7367740 \\
7367800 \\
7369250 \\
7369500 \\
7369700\end{array}$ & $\begin{array}{l}\text { S2 } \\
\text { S2 } \\
\text { S2 } \\
\text { S2 } \\
\text { S2 }\end{array}$ & $\begin{array}{r}-0.496 \\
0.799 \\
1.140 \\
-0.640 \\
-1.722\end{array}$ \\
\hline $\begin{array}{l}2476500 \\
2477000 \\
2477050 \\
2477090 \\
2477350\end{array}$ & $\begin{array}{l}\text { S1 } \\
\text { SI } \\
\text { SI } \\
\text { SI } \\
\text { SI }\end{array}$ & $\begin{array}{r}0.085 \\
-0.059 \\
0.298 \\
0.638 \\
0.307\end{array}$ & $\begin{array}{l}7047200 \\
7047600 \\
7047924 \\
7047942 \\
7077500\end{array}$ & $\begin{array}{l}\text { S2 } \\
\text { S2 } \\
\text { S2 } \\
\text { S2 } \\
\text { S2 }\end{array}$ & $\begin{array}{r}-0.451 \\
-0.078 \\
0.255 \\
-0.791 \\
0.196\end{array}$ & $\begin{array}{l}7370000 \\
7373500 \\
7373550 \\
7375800 \\
7376760\end{array}$ & $\begin{array}{l}\text { S2 } \\
\text { S3 } \\
\text { S3 } \\
\text { S3 } \\
\text { S3 }\end{array}$ & $\begin{array}{r}0.017 \\
-0.418 \\
-0.197 \\
0.152 \\
0.001\end{array}$ \\
\hline $\begin{array}{l}2477500 \\
2478500\end{array}$ & $\begin{array}{l}\text { S1 } \\
\text { S1 }\end{array}$ & $\begin{array}{l}0.497 \\
0.696\end{array}$ & $\begin{array}{l}7077700 \\
7077860\end{array}$ & $\begin{array}{l}\text { S2 } \\
\text { S2 }\end{array}$ & $\begin{array}{l}-0.294 \\
-1.371\end{array}$ & $\begin{array}{l}7377000 \\
7377400\end{array}$ & $\begin{array}{l}\text { S3 } \\
\text { S3 }\end{array}$ & $\begin{array}{l}-0.499 \\
-0.115\end{array}$ \\
\hline
\end{tabular}



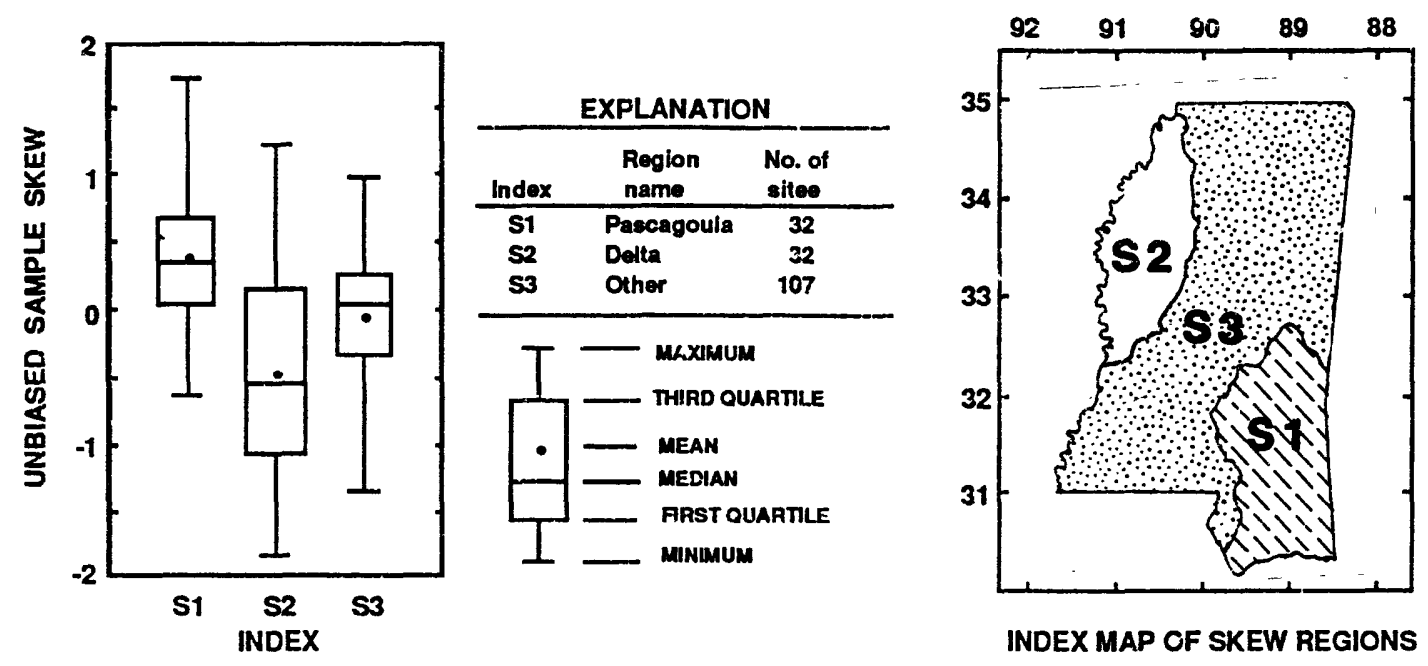

Figure 14.- - Skew coefficient characteristics and boundaries of homogeneous skew regions in Mississippi

The null hypothesis that the mean of the subgroup is equal to the mean of the whole-sample group was rejected for regions S1 and S2 using the twosample t-test at p-values of 0.0001 and 0.011 , respectively. The hydrologic significance of the skew regions is described by Landers (1989). The significance of skew as a function of some hydrologic characteristics can be reasoned and observed. Large variations in skew between similar regions may not be attributable to apparent hydrologic factors. The sharp transition in skew along parts of the boundary between region S1 and S3 represents skew values from long-term gages in this area. However, the authors are not convinced that this transition has hydrologic significance. The magnitude of variation between the station skews in this region is reduced on the skew map by the regionalization method used. Given the somewhat limited understanding of skew in many instances, the authors decided not to disqualify the results of the technique that had been carefully developed and worked well elsewhere in the State.

The best weighted-grid contour map for each region was selected based on least-mean-square residual and judgement. Mapping variables include the grid definition, the search procedure used around each grid node, and the degree of smoothing applied. Greater smoothing generally will produce larger errors of estimate; however, greater smoothing may increase the 
accuracy of the map in estimating regional skew coefficients. Regicnal skew coefficients may be taken from the the weighted-grid contour map shown in figure 15. Contour lines are shown within State boundaries only. Regional skew coefficients for basins located in both regions S2 and S3 would be selected using judgement, and taking into consideration the flood-flow storage characteristics of the Mississippi River Alluvial Plain, which may be more related to the local slope and drainage boundaries than to the regional percentage of basin drainage area.

An estimate of population skew is required to calculate flood-frequencies using the Pearson Type III distribution. The IACWD (1982) recommends that population skew be estimated as the weighted average of the sample skew and regional skew. The IACWD (1982) uses mean square error as an estimate of sampling variance $\left(\mathrm{MSE}_{\mathbf{r}}\right.$ ) to weight regional skew in equation 5. An alternative estimate of the sampling variance of the regional skew coefficient is the mean sum of squared prediction errors, or MPRESS statistic. The MPRESS statistic has the advantage, as compared with mean square error, of not requiring an estimate of the degrees of freedom, which may be unknown for a map estimator. The MPRESS statistic is calculated by splitting the original sample of $\mathbf{m}$ points into two sets: a calibration set of size $\mathbf{m - 1}$, and a validation set of size one. The estimator is then computed from the calibration set and used to estimate $\hat{\mathbf{Y}}_{\mathbf{V} \mathbf{i}}$ for the validation point $\left(\mathrm{Y}_{\mathbf{V} \mathbf{i}}\right)$. The predictive discrepancy is computed by (Yvi $\left.-\hat{Y}_{v i}\right)$. This is done for each observation in the original sample so the mean sum of squared prediction errors is simply:

$$
\text { MPRESS }=\sum_{i=1}^{m} \frac{\left(Y_{v_{i}}-\hat{Y}_{v_{i}}\right)^{2}}{m}
$$

The MPRESS statistic for the weighted-grid contour map for each region is shown in figure 16. This estimate of sampling variance was used in equation 5 to estimate population skew when computing flood-frequency using the Pearson Type III distribution. 


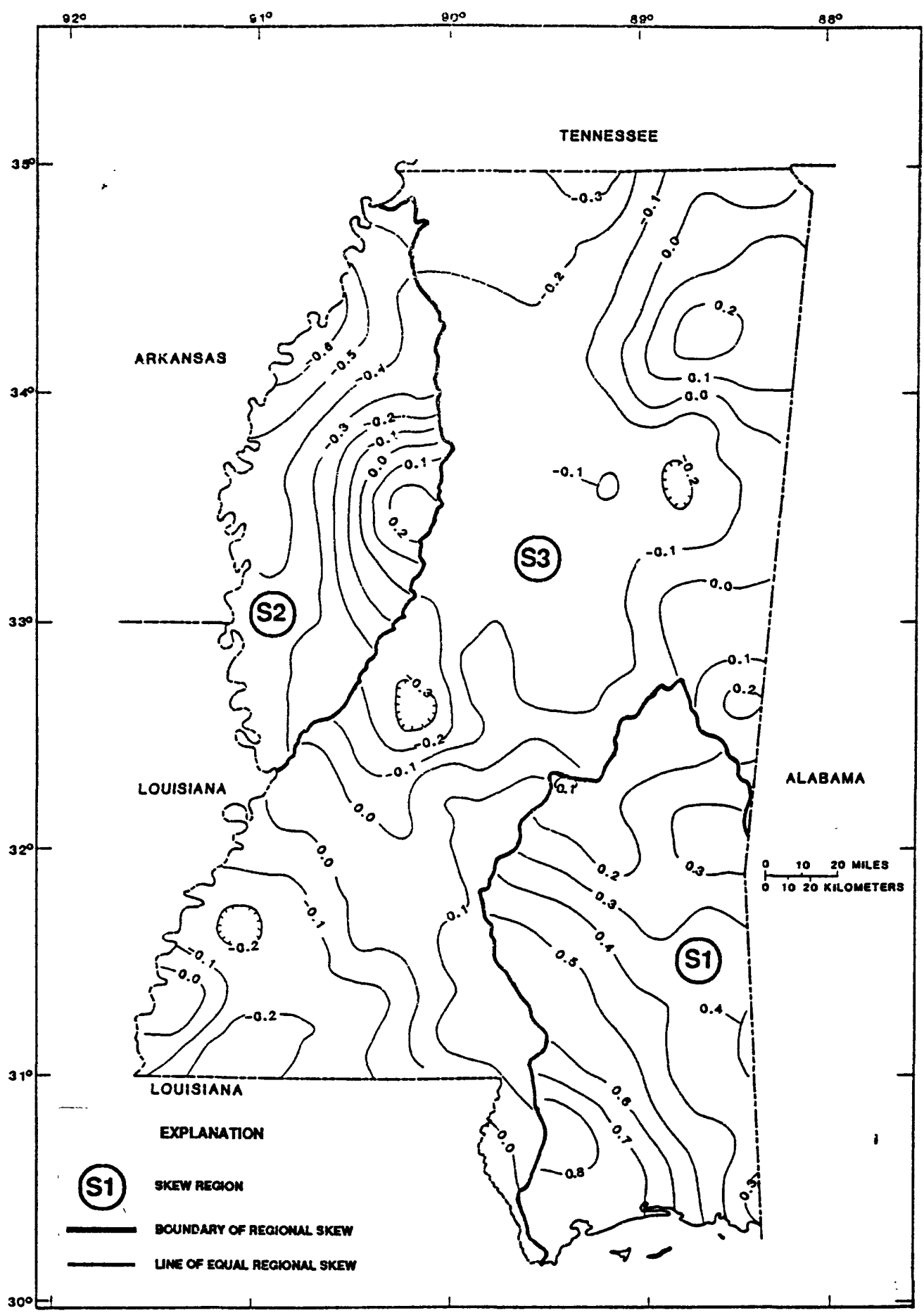

Figure 15.--Weighted-grid unbiased regional skew of log-transformed annual peak flow. 


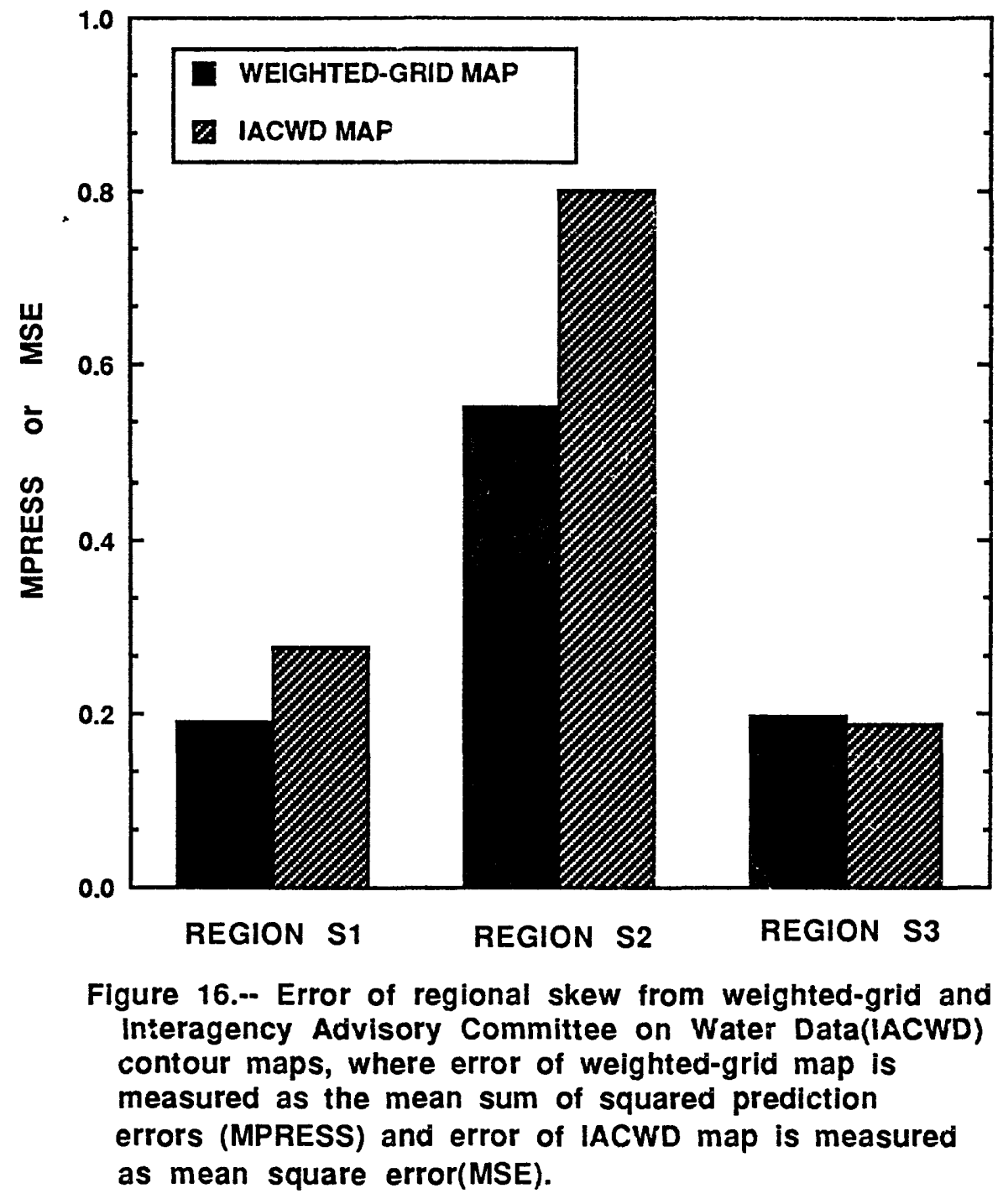

The estimated mean square error (MSE) of the IACWD skew, map (1982) was determined (assuming m-2 degrees of freedom) for the stations in each region and is also shown in figure 16. The MSE of the IACWD skew map is larger than the MPRESS of the weighted methods in regions S1 and S2, and is smaller than the MPRESS of the weighted methods in region S3. Regional skew coefficients are weighted with sample skew to provide a better estimate of the population skew coefficient of log-transformed annual peak flow. The accuracy of flood-frequency estimates from records of annual peak flow is improved by correcting for bias in sample skew coefficients and by using weighted regional skew estimating methods. 